\title{
Ground-Water Quality and Geochemistry, Carson Desert, Western Nevada
}

By Michael S. Lico and Ralph L. Seiler

U.S. GEOLOGICAL SURVEY

Open-File Report 94-31

A product of the National Water-Quality Assessment ProgramCarson River Basin,

Nevada and California

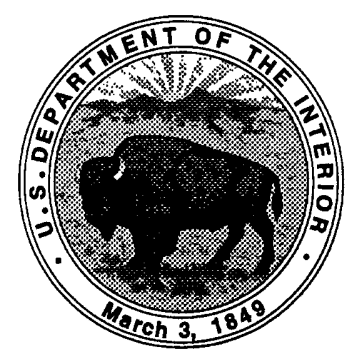

Carson City, Nevada 1994 


\title{
U.S. DEPARTMENT OF THE INTERIOR BRUCE BABBITT, Secretary
}

\author{
U.S. GEOLOGICAL SURVEY \\ GORDON P. EATON, Director
}

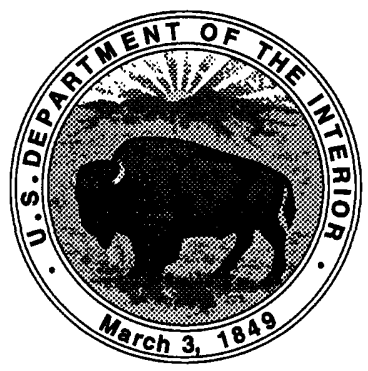

Any use of trade names in this publication is for descriptive purposes only and does not imply endorsement by the U.S. Government.

For additional information write to:

District Chief

U.S. Geological Survey 333 West Nye Lane, Room 203 Carson City, NV 89706-0866
Copies of this report can be purchased from:

U.S. Geological Survey Earth Science Information Center Open-File Reports Section Box 25286, MS 517 Denver Federal Center Denver, CO 80225-0046 


\section{CONTENTS}

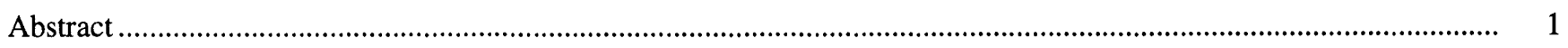

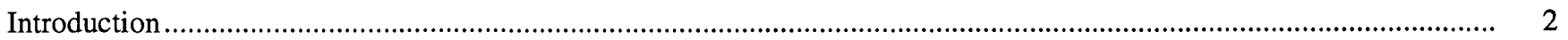

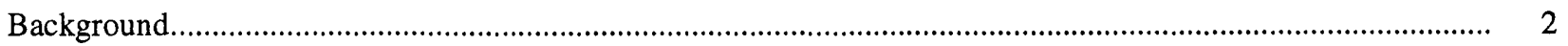

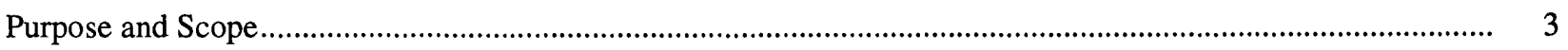

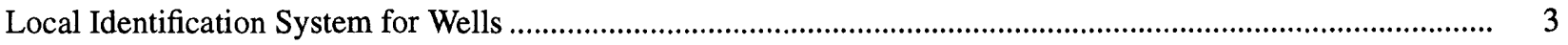

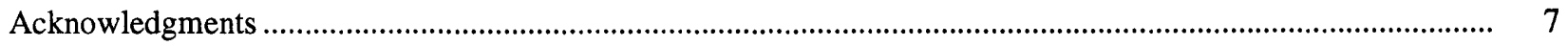

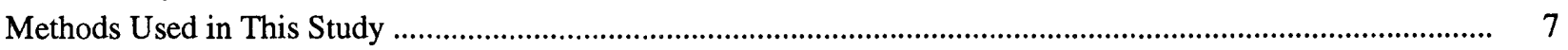

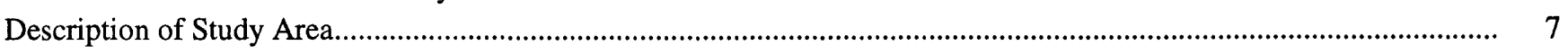

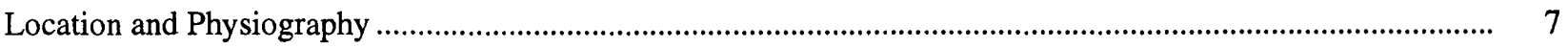

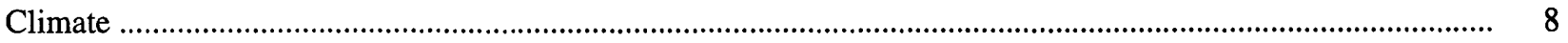

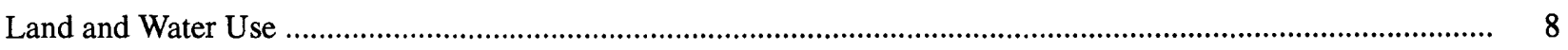

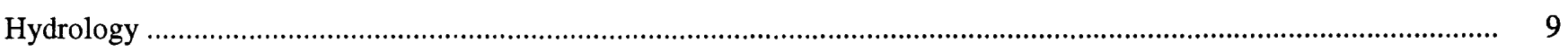

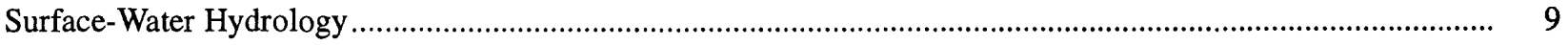

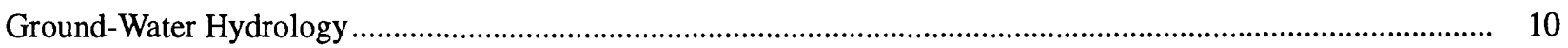

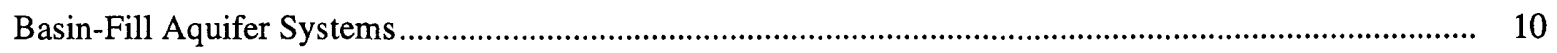

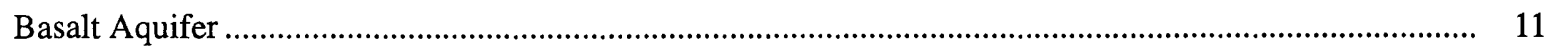

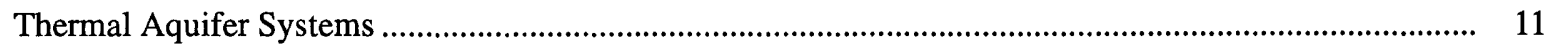

Mineralogic Composition of Basin-Fill Sediments and the Basalt Aquifer .............................................. 13

Movement of Ground Water and Isotope Hydrology ............................................................................. 14

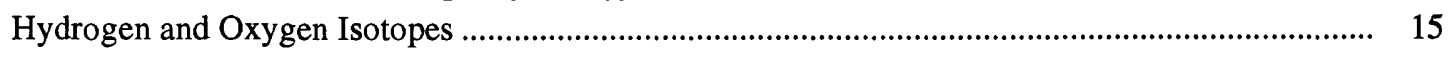

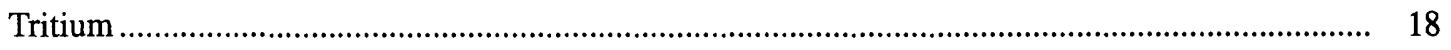

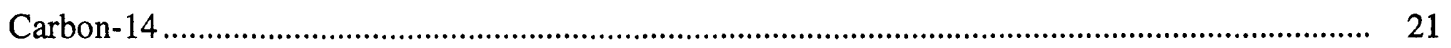

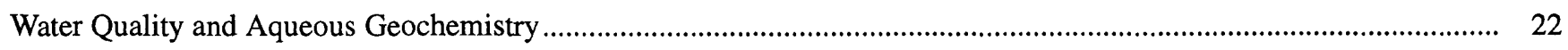

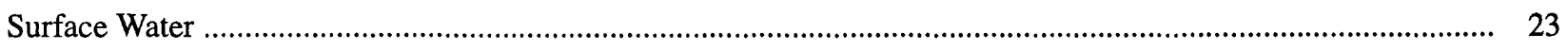

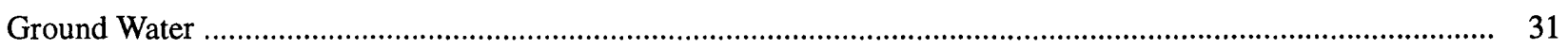

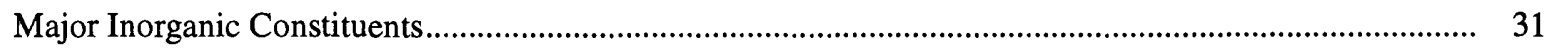

Relation to Nevada State Drinking-Water Standards .............................................................. 31

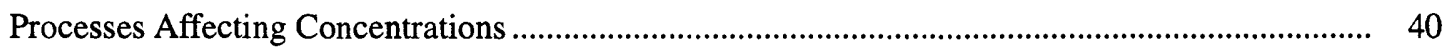

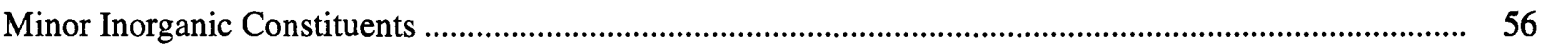

Relation to Nevada State Drinking-Water Standards ............................................................. 56

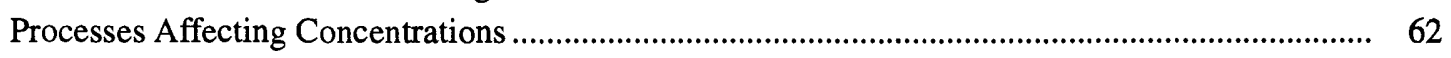

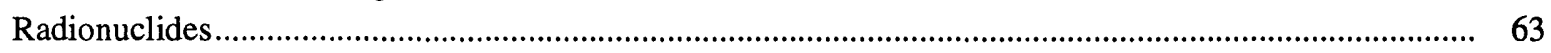

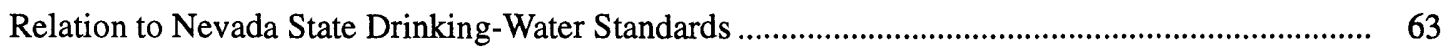

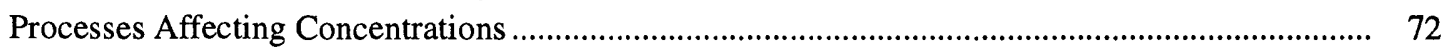

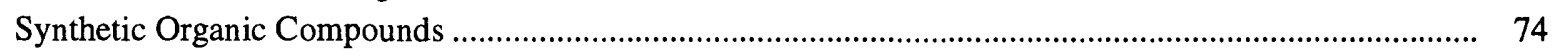

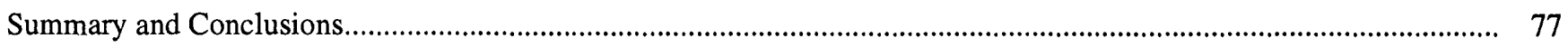

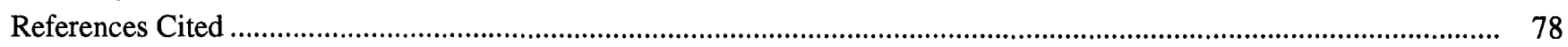

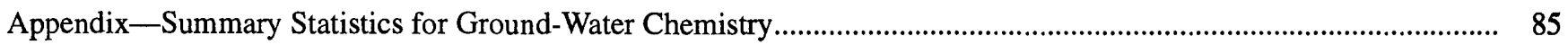

\section{FIGURES}

1-3. Maps showing:

1. Features of Carson Desert hydrographic area within Carson River Basin ............................................. 4

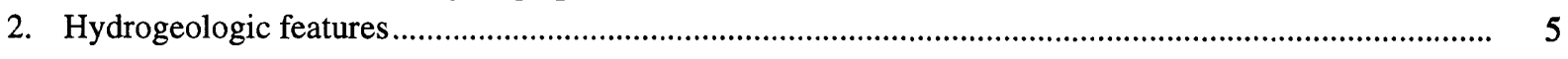

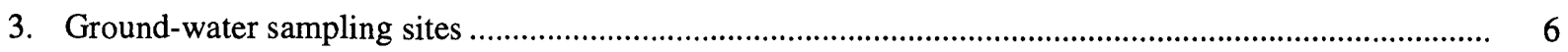


4-6. Graphs showing:

4. Estimated irrigated acreage, water diversions, and water delivered to farms

in the Newlands Project, Carson Desert, and Fernley hydrogeographic areas, 1914-87 ........................... 9

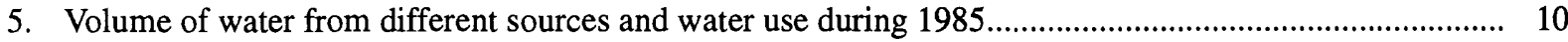

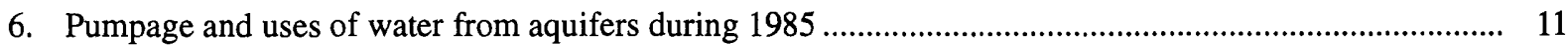

7-8. Maps showing:

7. Extent of the basalt aquifer at a depth of 1,000 feet beneath the Fallon area based on drillers' logs and electrical resistivity measurements.

8. Stable-isotope composition of hydrogen (deuterium) in ground water at selected sites............................... 16

9. Diagram showing the relation between the stable-isotope composition

of hydrogen (deuterium) and oxygen in ground water

10. Map showing tritium concentrations in ground water at selected sites .

11-13. Diagrams showing:

11. Concentrations of major constituents and dissolved solids in the Carson River downstream of Lahontan Reservoir for the period 1978-89

12. General chemical composition of water.

13. Concentrations of major constituents and dissolved solids in ground water............................................ 32

14. Map showing dissolved-solids concentrations in ground water

15. Schematic diagram showing the generalized hydrology and geohydrologic processes affecting the chemistry of water in the shallow basin-fill aquifers

16-17. Map showing wells with concentrations of dissolved constituents that exceed

Nevada State drinking-water standards for:

16. Secondary maximum contaminant levels

17. Primary maximum contaminant levels

18-23. Diagrams showing:

18. Relation between the concentration of sulfate and the stable-isotope composition of sulfur in sulfate and the relation between the concentration of sulfate and chloride in ground water.

19. Relation between the stable-isotope composition of carbon and the concentration of dissolved inorganic carbon in ground water

20. Median amounts of mass transfer for geochemical reactions

21. Relation between chemical activities of major constituents in ground water

22. Saturation indices for ground-water samples

23. Concentrations of minor constituents in ground water.

24-25. Maps showing concentrations of dissolved:

24. Arsenic in ground water .

25. Boron in ground water.

26-31. Diagrams showing:

26. Relation between boron and chloride concentrations in ground water

27. Relations between the dissolved constituents in ground water

28. Relations between dissolved iron and the saturation index for siderite, and dissolved manganese and saturation index for rhodochrosite in ground water.

29. Radioactivity caused by gross alpha, uranium, radium-226, gross beta, radium-228, and radon-222 in ground water.

30. Relation between uranium concentrations and gross-alpha activity in ground water

31. Relation between uranium concentrations and gross-beta activity minus the estimated contribution from potassium- 40 in ground water.

32-33. Maps showing:

32. Radon-222 concentrations in ground water at selected sites

33. Wells that exceed proposed U.S. Environmental Protection Agency maximum contaminant levels for radionuclides in ground water 


\section{TABLES}

1. Activities of tritium and carbon-14 and estimated ages of ground water from selected sites in the Carson Desert.

2. Nevada State drinking-water standards for public water systems ................................................................. 23

3. Concentrations of major constituents, physical properties, stable-isotope composition, and well depths for selected sites in the Carson Desert....

4. Number of sites in the Carson Desert where inorganic constituents exceed Nevada State drinking-water maximum contaminant levels and secondary maximum contaminant levels in ground water compared to total number of sites

5. Minerals identified and phases included in geochemical models, their composition, and rationale for inclusion in geochemical models of the Carson Desert

6. Selected analysis for dissolved constituents in ground-water samples used as initial compositions in geochemical models of the Carson Desert .

7. Saturation indices for selected minerals in ground-water sample as calculated by the computer program WATEQ4F

8. Concentrations of minor constituents in ground water at selected sites in the Carson Desert ............................ 58

9. Concentrations of radionuclides in ground water from selected sites in the Carson Desert.................................. 67

10. Total number of sites and radionuclide analyses that exceed Nevada State primary maximum contaminant levels and maximum contaminant levels proposed by the U.S. Environmental Protection Agency in ground water.

11. Synthetic organic compounds and their analytical reporting levels for ground-water samples 75

\section{CONVERSION FACTORS, VERTICAL DATUM, AND ABBREVIATED WATER-QUALITY UNITS}

\begin{tabular}{rll}
\hline Multiply & By & To obtain \\
\hline acre & 0.4047 & square hectometer \\
acre-foot (acre-ft) & 0.001233 & cubic hectometer \\
acre-foot per year (acre-ft/yr) & 1,233 & cubic meter per year \\
foot (ft) & 0.3048 & meter \\
foot per year (ft/yr) & 0.3048 & meter per year \\
inch (in.) & 25.40 & millimeter \\
inch per year (in/yr) & 25.40 & millimeter per year \\
mile (mi) & 1.609 & kilometer \\
\hline
\end{tabular}

Temperature: Degrees Celsius $\left({ }^{\circ} \mathrm{C}\right)$ can be converted to degrees Fahrenheit $\left({ }^{\circ} \mathrm{F}\right)$ by using the formula ${ }^{\circ} \mathrm{F}=\left[1.8\left({ }^{\circ} \mathrm{C}\right)\right]+32$. Degrees Fahrenheit can be converted to degrees Celsius by using the formula ${ }^{\circ} \mathrm{C}=0.556\left({ }^{\circ} \mathrm{F}-32\right)$.

Sea level: In this report, "sea level" refers to the National Geodetic Vertical Datum of 1929 (NGVD of 1929, formerly called "Sea-Level Datum of 1929"), which is derived from a general adjustment of the first-order leveling networks of the United States and Canada.

\footnotetext{
Abbreviated Water-Quality Units Used in this Report

$\mu \mathrm{g} / \mathrm{L} \quad$ (microgram per liter)

$\mathrm{mg} / \mathrm{kg} \quad$ (milligram per kilogram)

$\mathrm{mg} / \mathrm{L} \quad$ (milligram per liter)

$\mathrm{pCi} / \mathrm{L} \quad$ (picocurie per liter)

$\mathrm{mmol} / \mathrm{L} \quad$ (millimole per liter)

$\mu \mathrm{S} / \mathrm{cm} \quad$ (microsiemens per centimeter at $25^{\circ} \mathrm{C}$ )
} 


\title{
Ground-Water Quality and Geochemistry, Carson Desert, Western Nevada
}

\author{
By Michael S. Lico and Ralph L. Seiler
}

\section{Abstract}

Basalt and basin-fill (alluvial and lacustrine) aquifers that underlie the Carson Desert are the primary source of public water supplies for the residents. The city of Fallon and the Fallon Naval Air Station derive all of their water supply from the basalt aquifer directly beneath the city. Most of the residents in rural areas of Carson Desert obtain their water from wells completed in the shallow and intermediate basin-fill aquifers.

Thermal water is used for heating and generating electricity in parts of the Carson Desert. Sedimentary deposits in the Carson Desert may be as thick as 8,000 feet, although only the upper 500 feet is used for water supplies.

The principal source of recharge to the shallow basin-fill aquifers is infiltration of surface water from irrigation and the numerous river channels, canals, and ditches that crisscross the southern Carson Desert. Other sources of recharge to the shallow aquifers include infiltration of precipitation in low-lying areas after intense storms and precipitation in the surrounding mountains.

The present-day Carson and Truckee Rivers are not the principal source of water in the intermediate and basalt aquifers. Samples collected from wells completed in the intermediate aquifer have carbon-14 ages ranging from the present to 7,700 years. Samples from wells completed in the basalt aquifer have carbon-14 ages ranging from 1,100 to 8,100 years. Tritium concentrations in ground water indicate that some water from canals is recharging the basalt aquifer; however, canal water is probably only a minor component of recharge to the aquifer.

Ground water generally flows to discharge areas in the northeast, south, and southeast. Widespread irrigation that began in the early 1900's has resulted in a rise of the water table in the Carson Desert. The rise was as much as 60 feet in the Soda Lakes area, but probably is much less in most of the Carson Desert, especially in the discharge areas near Carson Lake and Stillwater Wildlife Management area.

The chemical composition of water in the aquifers of the Carson Desert is highly variable. In the shallow basin-fill aquifers, ground water varies from a dilute calcium bicarbonate type to a saline sodium chloride type. Generally, the more dilute water is present beneath the irrigated areas and the more chemically concentrated waters are present in unirrigated areas. The water in more than 50 percent of the ground-water samples referred to in this report have dissolved-solids concentrations that exceed Nevada State drinking-water standards. Many of these same samples also exceed standards for magnesium, chloride, and sulfate. The locations of samples with high concentrations of dissolved solids, magnesium, chloride, and sulfate commonly are in discharge areas. Arsenic and manganese concentrations commonly exceed drinking-water standards, but concentrations at only a few sites exceed standards for fluoride and nitrate. Water in the intermediate basin-fill aquifers is a dilute sodium bicarbonate water in the Fallon area and a distinctly more saline sodium chloride water in the Soda Lakes-Upsal Hogback 
area. Dissolved solids and chloride concentrations commonly (more than 50 percent of the samples) exceed drinking-water standards. Arsenic, fluoride, and manganese concentrations commonly exceed standards. The basalt aquifer, the primary source of drinking water for the city of Fallon, contains a dilute sodium bicarbonate chloride water. Arsenic concentrations exceed standards in all samples included in this study.

The chemical character of water in the aquifers beneath the southern Carson Desert is the result of evapotranspiration and natural geochemical reactions with minerals derived mostly from igneous rocks. Results of mass-balance modeling, combined with thermodynamic and mineralogic data, are consistent with major ion concentrations being the result of reaction with plagioclase feldspar, calcite, augite, carbon dioxide, beidellite, and small amounts of potassium feldspar, gypsum, silica, sodium chloride, and pyrite. The exchange of calcium for sodium on clay minerals also is a common reaction in all the models.

Dissolved oxygen probably is the major control on iron and manganese concentrations in the ground water of the Carson Desert, primarily because of the increased solubility of the chemically reduced forms of these elements. Water with high concentrations of iron and manganese is near thermodynamic equilibrium with siderite and rhodochrosite. This indicates that the concentrations of these elements may be limited by the solubility of their respective carbonate minerals. The rise in the water table caused by infiltration of irrigation water may have caused a reduction in the redox conditions (lower dissolved oxygen concentration), thus allowing dissolution of iron and manganese oxides and the release of minor constituents (such as arsenic) associated with the oxides. Where dissolved oxygen is present, sedimentary organic matter may be oxidizing and releasing adsorbed minor constituents.

Naturally occurring radionuclides (uranium and radon-222) are present in ground water from the Carson Desert in concentrations higher than proposed U.S. Environmental Protection Agency drinking-water standards. High uranium concentrations in the shallow aquifers may be caused by the release of uranium by dissolution of iron and manganese oxides. Another possible source for uranium may be the oxidation of sedimentary organic matter that typically has high concentrations of uranium. Radon- 222 concentrations in the ground water are not supported by concentrations of dissolved radium-226. This observation indicates that radium-226 must be present in grain coatings, sedimentary organic matter, or some other mineral form and that the radon- 222 is coming from these solid-phase sources.

Ground water in the Carson Desert appears not to have been significantly contaminated by synthetic organic chemicals. Water from one site has a detectable concentration of 1,2-Dichloroethane, but does not exceed the State drinking-water standard. No other volatile organic compounds were detected in samples of ground water from this area. Samples from four sites have detectable concentrations of Dicamba. Silvex, Simazine, and 2, 4-D are detectable at low concentrations in water samples from one well each.

\section{INTRODUCTION}

\section{Background}

Beginning in 1986, Congress has annually appropriated funds for the U.S. Geological Survey to test and refine concepts for a National Water-Quality Assessment (NAWQA) Program. The long-term goals of a full-scale program are:

1. Provide a nationally consistent description of current water-quality conditions for a large part of the Nation's surface- and ground-water resources,

2. Define long-term trends (or lack of trends) in water quality, and

3. Identify, describe, and explain, as possible, the major factors that affect the observed water-quality conditions and trends.

The information obtained will be available to water managers, policy makers, and the public to provide an improved scientific basis for evaluating 
the effectiveness of water-quality management programs and to provide a data base for assessing the likely effects of contemplated changes in land-and water-management practices. Concepts for a full-scale NAWQA Program are described by Hirsch and others (1988). The NAWQA Program is organized into study units on the basis of specific hydrologic systems. The study units are large, involving areas of a few thousand to several tens of thousands of square miles. This report presents results of part of a pilot phase of NAWQA that was done in the Carson River Basin, one of the seven areas selected throughout the United States to represent diverse hydrologic environments and water-quality conditions. The seven pilot projects include four surface-water and three ground-water studies. The surface-water project areas are the Yakima River Basin in Washington; the lower Kansas River Basin in Kansas and Nebraska; the upper Illinois River Basin in Illinois, Indiana, and Wisconsin; and the Kentucky River Basin in Kentucky. The ground-water project areas are the Carson River Basin in western Nevada and eastern California; the Central Oklahoma aquifer in Oklahoma; and the Delmarva Peninsula in Delaware, Maryland, and Virginia.

The Carson River Basin pilot project included studies of several areas within the basin. Some of the studies have produced reports concerned with water issues and related topics of special interest. Reports of studies in Carson and Eagle Valleys (Welch, 1994), and Dayton and Churchill Valleys (Thomas and Lawrence, 1994) provide a description of the geochemistry and ground-water quality interpreted from data collected specifically for the NAWQA Program from 1987 through 1990 and data previously collected by the U.S. Geological Survey. These reports complement and update geochemical and hydrologic data available through 1987, summarized by Welch and others (1989). Topics of special interest include the effects of urbanization on water quality (Lawrence and Whitney, 1990), radionuclides (Thomas and others, 1993; Thomas and others, 1990; Welch and others, 1990), minor constituents (Welch and others, 1988; A.H. Welch, U.S. Geological Survey, written commun., 1992), data on sediment chemistry (Tidball and others, 1991), and the relation between water quality and the geochemistry of shallow sediments (E.A. Frick, U.S. Geological Survey, written commun., 1992).

In arid parts of the western United States, potable water is scarce and future development depends on its availability. Rapid population growth in the Carson Desert area of western Nevada (figs. 1 and 2) since the 1970's has increased the demand for potable water, much of which is derived from aquifers. Most of the ground water in the Carson Desert is only marginally potable, making the task of finding usable water resources difficult.

Dissolved-solids concentrations commonly exceed drinking-water standards in parts of the Carson Desert and expensive treatment of the water may be required before the water is suitable for consumption. Taste and odor problems caused by iron, manganese, and hydrogen sulfide (rotten-egg odor) make the water in parts of the basin unpalatable or even unsuitable for drinking. In some areas, arsenic concentrations greatly exceed drinking-water standards; one case of arsenic poisoning has been reported (Glancy, 1986, p. 48).

\section{Purpose and Scope}

The primary purpose of this report is to describe the quality of the ground water in the southern Carson Desert, with an emphasis on the water in aquifers used for domestic or public water supply. The description of the water quality includes a discussion of the general water quality and the physical and chemical processes that produce the observed quality. Data collected from 1987 to 1990 as part of the Carson River Basin NAWQA project are the primary source of information in this report, although other data are included, particularly for the areas where little new sampling was done.

\section{Local Identification System for Wells}

Ground-water site locations in tables, figures, and text of this report are identified by site numbers. Site locations are shown on figure 3 . The locations are further described as "site identifications" using local well numbers which are based on the rectangular subdivision of public lands, referenced to the Mount Diablo base line and meridian. A complete designation of a site consists of: (1) the township number north of the base line; (2) the range east of the meridian; (3) the section number; (4) letters designating the quarter section, quarter-quarter section, and so-on (the letters A, B, C, and D indicate northeast, northwest, southwest, and southeast quarters, respectively); and (5) a sequence number that distinguishes between 
wells that lie in the same tract within the section. For example, well N19 E28 21BBCA1 is the first recorded in the NE $1 / 4$ of the SW $1 / 4$ of the NW $1 / 4$ of the
NW $1 / 4$ of section 21 , township 19 north, range 28 east. Township and range numbers are shown along the margins of maps within this report.

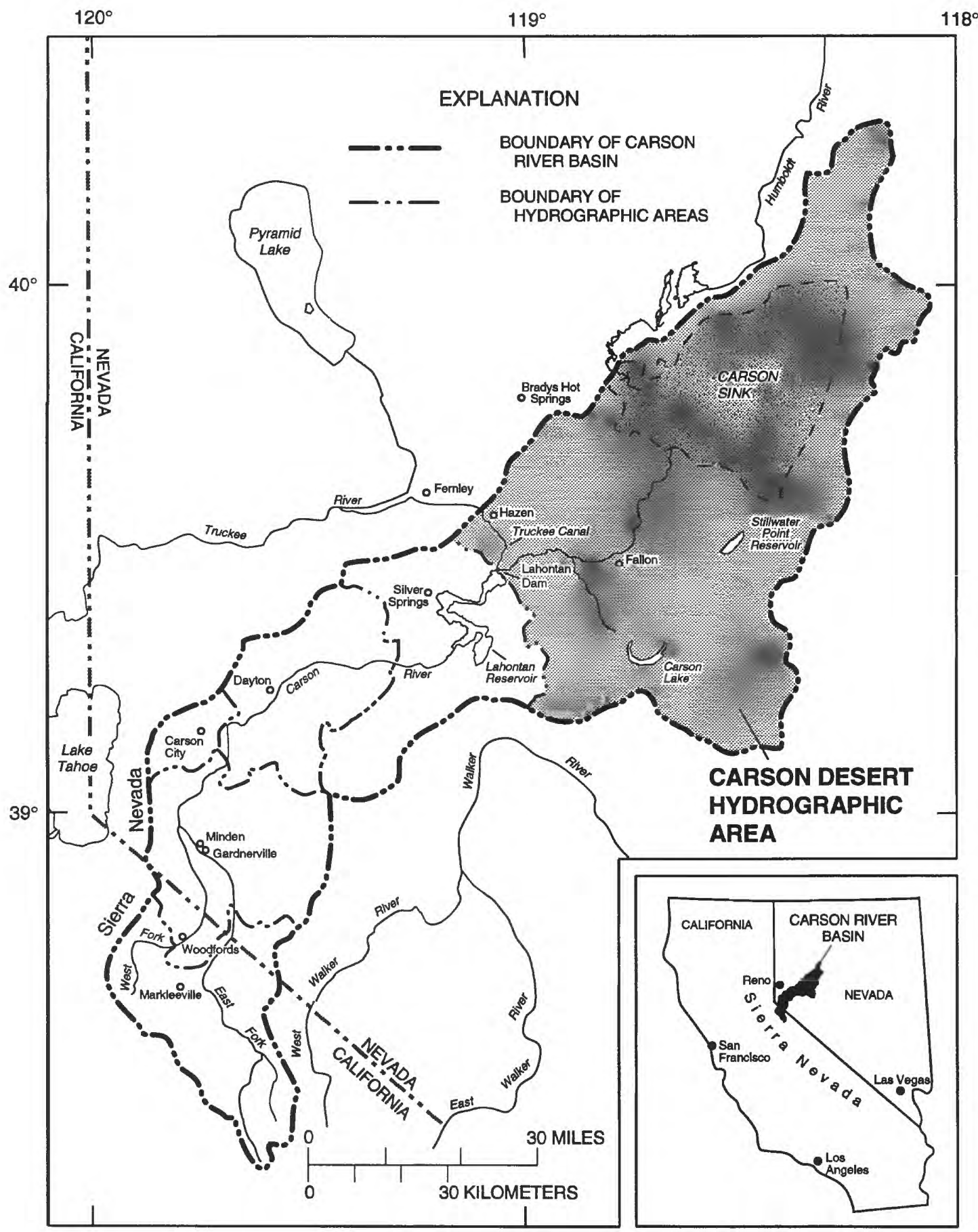

Figure 1. Features of Carson Desert hydrographic area within Carson River Basin. 


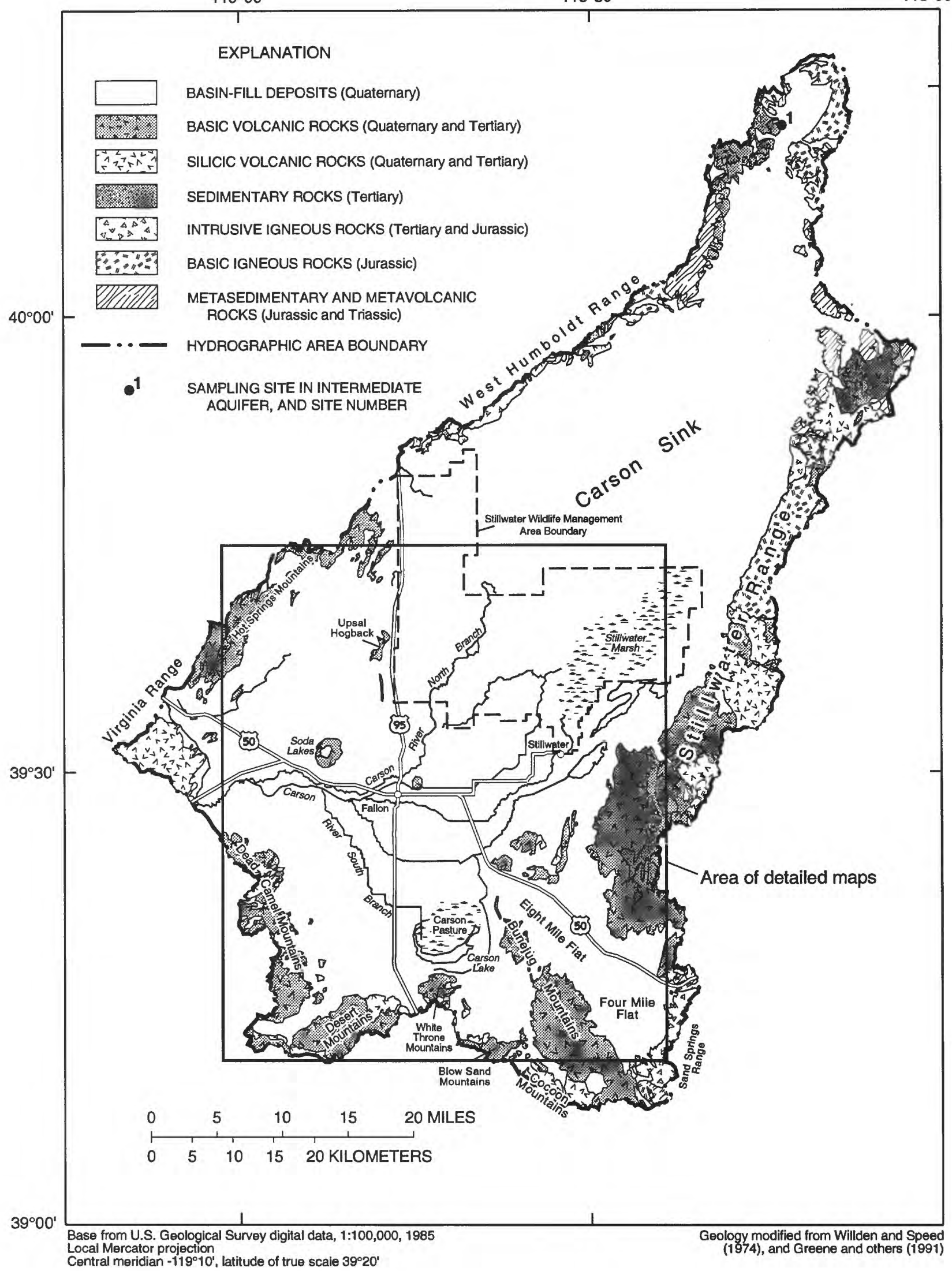

Figure 2. Hydrogeologic features of Carson Desert. 


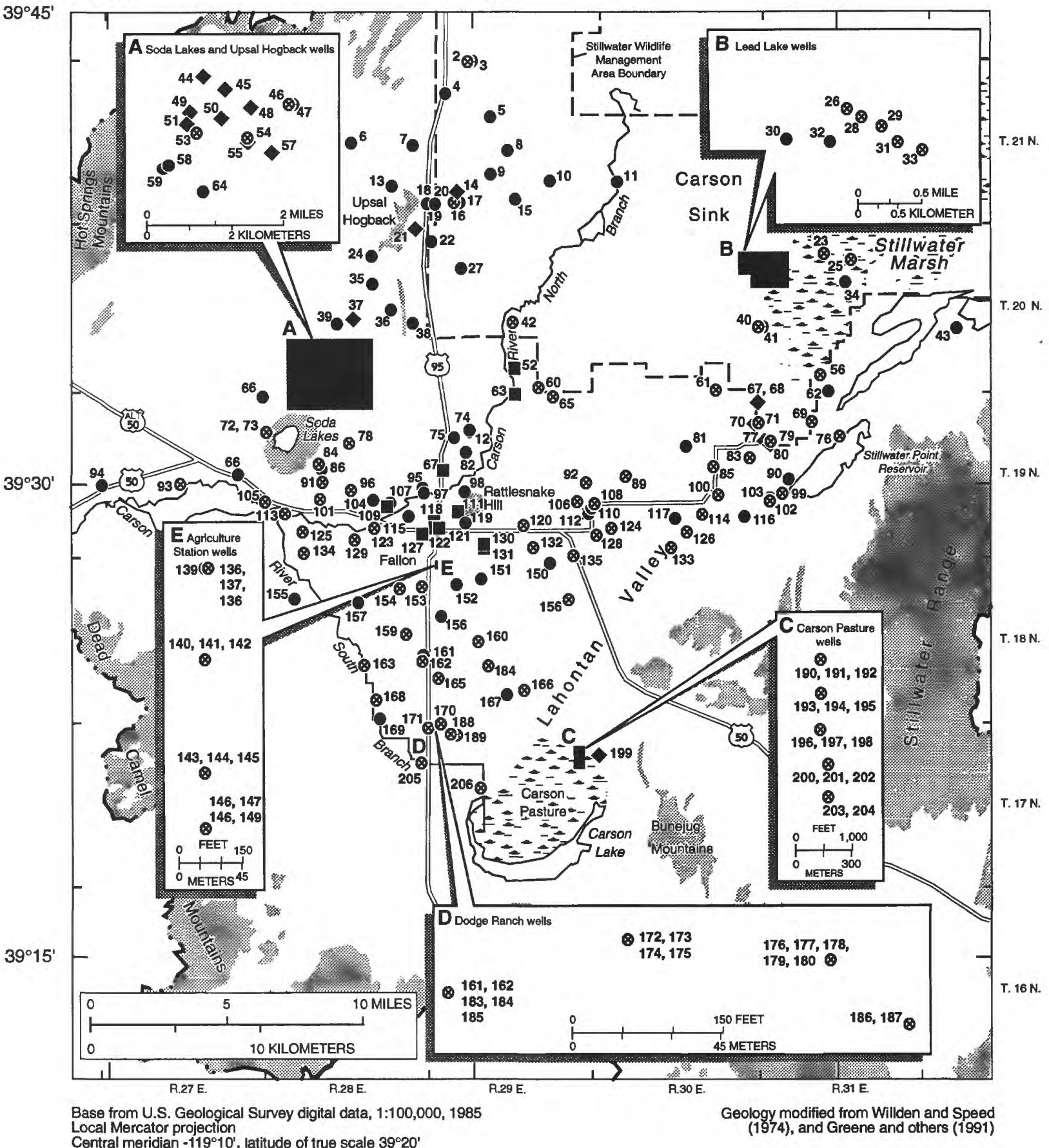

Central meridian $-119^{\circ} 10^{\prime}$, latitude of true scale $39^{\circ} 20^{\prime}$

EXPLANATION

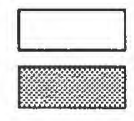

BASIN-FILL DEPOSITS

CONSOLIDATED ROCKS

-.. HYDROGRAPHIC AREA BOUNDARY
SAMPLING SITE AND SITE NUMBER. Slte 1, In northem Carson Desert, Is shown in figure 2

$\begin{array}{ll}{ }^{129} & \text { Shallow aquifer } \\ 151 & \text { Intermedlate aqulfer } \\ 131 & \text { Basalt aquifer } \\ 199 & \text { Thermal aquifer }\end{array}$

Figure 3. Ground-water sampling sites in southern Carson Desert. 


\section{Acknowledgments}

The authors express their appreciation to residents of the Carson Desert, the Fallon Naval Air Station, and the city of Fallon for access to their land and wells for data-collection activities. We thank Larry Benson of the U.S. Geological Survey for providing stable-isotope values for the Truckee and Walker Rivers.

\section{Methods Used in This Study}

Sampling sites were selected using the overall design described by Welch and Plume (1987) for the entire Carson River Basin. Sampling included the use of existing wells and wells drilled specifically for the NAWQA program. In all, more than 200 sites with water-quality data were used to describe the water quality of the aquifers in the Carson Desert. The total numbers of sites used for the shallow, intermediate, basalt, and thermal aquifers were 124, 62, 11, and 17, respectively. Included in these sites were four areas that were studied to determine the processes responsible for observed water quality on a detailed scale. At the detailed sites, wells are closely spaced in both horizontal and vertical directions, to obtain data for determining geochemical processes. Two of these sites (at Dodge Ranch and Stillwater Wildlife Management Area) were used in previous studies (Lico and others, 1987; Rowe and others, 1991; Lico, 1992) and wells at two other sites were drilled specifically for this study. One of the detailed sites for this study was in an actively irrigated alfalfa field (Agricultural Station site) and the other was in an unirrigated area where the hydraulic gradient is upward (Carson Lake site). The boxplots and summary statistics of the water-quality data include only one representative sample from each of these four detailed study sites to avoid biasing the data set. The sites for the shallow aquifers include 15 additional wells in the Fallon area. The wells were drilled using the procedures described by Hardy and others (1989) and most were completed in the upper $30 \mathrm{ft}$ of the shallow aquifers. The drilling was done with a hollow-stem auger. Cores of the aquifer material were taken at the depths of screened intervals for analysis of the solid phase. A total of 372 shallow soil samples were collected at the drilled well sites and other sites throughout the Carson Desert (Tidball and others, 1991).
Ground water was sampled using the methods and protocols described by Hardy and others (1989) that included purging the wells with a positivedisplacement pump until concentrations of several monitored constituents $(\mathrm{pH}$, specific conductance, temperature, and dissolved oxygen) were constant prior to collecting the sample. Most constituents were analyzed by the U.S. Geological Survey National Water Quality Laboratory (NWQL) in Arvada, Colorado. Radionuclides (except radon-222) and the stable-isotope ratios of carbon and sulfur were analyzed by a contractor to the NWQL; stable isotopes of water were analyzed by the U.S. Geological Survey laboratory in Menlo Park, California. Tritium was analyzed for this NAWQA project at two different laboratories - the U.S. Geological Survey laboratory in Reston, Virginia and the Desert Research Institute laboratory in Reno, Nevada. Methods of analysis used by the laboratories are described by Fishman and Freidman (1985), Thatcher and others (1977), and Wershaw and others (1987).

Core samples were collected from the shallow basin-fill aquifers adjacent to well screens with a splitspoon sampler. The mineralogic composition of these 29 sediment samples from the shallow basin-fill aquifers was analyzed using petrographic microscope and $\mathrm{X}$-ray diffraction. Chemical analyses for splits of these samples are reported by Tidball and others (1991).

\section{DESCRIPTION OF STUDY AREA}

\section{Location and Physiography}

The Carson Desert hydrographic area, defined by the Nevada Division of Water Resources (Rush, 1968), is referred to as Carson Desert Basin in this report and covers an area of $2,163 \mathrm{mi}^{2}$. It is the terminus of the Carson River, which originates in the Sierra Nevada of California (fig. 1). The Carson Sink receives flow from the Carson River and the Humboldt River during periods of high flow.

The axis of Carson Desert trends northeast and the basin has a maximum length of about $70 \mathrm{mi}$ and a maximum width of about $25 \mathrm{mi}$. The basin floor is level and about $3,800 \mathrm{ft}$ above sea level. The basin is bounded to the northwest by the Hot Springs Mountains and the West Humboldt Range, to the east and southeast by the Stillwater and Sand Springs Ranges and the Bunejug and Cocoon Mountains, to the south by the Blow Sand, White Throne, and Desert 
Mountains, and to the west by the Virginia Range and the Dead Camel Mountains (fig. 2). The altitudes of adjacent mountains range from 4,500 to $8,800 \mathrm{ft}$ along the basin divides (Morrison, 1964, p. 5).

The major physiographic features of the Carson Desert Basin include mountains, alluvial fans and pediments, basin lowlands, the flood plain of the Carson River, and the Carson Sink-a large playa that occupies a major part of the northern Carson Desert Basin. Alluvial fans and pediments extend from the mountain front along basin margins toward the center of the basin. In some places, they merge with lowlands, and elsewhere they are truncated by the flood plain of the Carson River or the Carson Sink. Outcrops of basalt are scattered within the lowlands of the Carson Desert, notably at Soda Lakes, Rattlesnake Hill, and Upsal Hogback.

The Carson Desert is surrounded by mountains composed of a wide variety of igneous, sedimentary, and metamorphic rocks ranging in age from Quaternary to Triassic. The basin itself is underlain, in descending order, by (1) Holocene post-Lake Lahontan interbedded fluvial and eolian sediments,

(2) Pleistocene sediments of Lake Lahontan, (3) Quaternary and Tertiary sedimentary and volcanic rocks, and (4) pre-Tertiary igneous and sedimentary rocks. These deposits exceed $8,000 \mathrm{ft}$ in thickness within the Carson Desert Basin (Glancy, 1986). The stratigraphy and geology of the Carson Desert is described by Morrison (1964) and Willden and Speed (1974).

The major hydrographic features of the Carson Desert Basin (fig. 2) are distributary channels of the Carson River, marshes, shallow intermittent lakes, and salt flats. The Soda Lakes are in the remnant crater formed by repeated explosive eruptions in the western part of the basin. The Carson and Truckee Rivers provide inflow (by way of the Truckee Canal) to Lahontan Reservoir. Lahontan Dam was completed in 1915 just upstream of the Carson Desert to store water for irrigation in the Carson Desert. Other constructed hydrologic features include a complex system of irrigation canals, laterals, drains, and several control reservoirs for the irrigation system.

\section{Climate}

The climatic zone of Carson Desert is termed a mid-latitude semiarid desert. The Carson Desert lies in the rainshadow of the Sierra Nevada (Houghton and others, 1975, p. 6) and because of this, much of the moisture carried by winter storms from the Pacific Ocean doesn't reach the Carson Desert, but falls as snow or rain in the mountains. The mean daily minimum air temperature during January is $46.6^{\circ} \mathrm{F}$ at Fallon and the mean daily maximum temperature during July is $92.5^{\circ} \mathrm{F}$ for the period of record between 1941 and 1970 (Dollarhide, 1975, p. 2-3). Precipitation in the Carson Desert Basin falls as winter snow and rain at lower altitudes, and as summer thundershowers. The average annual precipitation from 1941 to 1970 was about 5 in. at Fallon weather station. Evapotranspiration has been estimated to range from 34 to $60 \mathrm{in} / \mathrm{yr}$ (Pennington, 1980; Morgan, 1982; U.S. Bureau of Reclamation, 1987).

\section{Land and Water Use}

Historically, land use in the Carson Desert has been dominantly agricultural. The construction of the Newlands Project, the first Federal irrigation project in the arid west, by the U.S. Bureau of Reclamation during the early 1900 's provided water to irrigate parts of the Carson Desert. Since 1914, irrigated acreage in the Newlands Project area, which includes land along the Truckee Canal in the Fernley area, has ranged from 39,449 acres in 1916 to 67,294 acres in 1979 (fig. 4). Between 1975 and 1984, water diverted from Lahontan Reservoir for irrigation in the Carson Desert has ranged from 181,831 acre-ft in 1980 to 352,649 acre-ft in 1979 (U.S. Bureau of Reclamation, 1986). The average amount of water diverted to the Newlands project during this period was 299,513 acre-ft. From 1987 to the present (1992), western Nevada has been experiencing drought conditions resulting in less than normal deliveries of water to farms in the Carson Desert. Beginning in 1990, the U.S. Fish and Wildlife Service, with the help of private interests and public funding, has been purchasing water rights from willing sellers in the Carson Desert to provide freshwater for the wetlands in the Stillwater Wildlife Management Area and other parts of Lahontan Valley. The agricultural lands from which water rights are purchased will eventually return to native vegetation.

The sources of water and water use in the Carson Desert during 1985 are shown in figure 5. Estimated total water use in the Carson Desert Basin for 1985 was about 347,000 acre-ft, of which more than 98 percent $(341,000$ acre-ft) was surface-water for irrigation. Although ground water accounts for only 1 percent 
of the total water used, it supplied almost 100 percent $(3,650$ acre-ft) of the amount used for public water supply and self-supplied domestic use (fig. 6).

\section{HYDROLOGY}

\section{Surface-Water Hydrology}

The Carson River enters the Carson Desert Basin just below Lahontan Dam. Average flow of the river below the dam, including Truckee River water diverted to Lahontan Reservoir by way of the Truckee Canal, was 378,000 acre-ft/yr for the period 1919-69 (Glancy and Katzer, 1975, p. 26).

Most of the Carson River flow is diverted for irrigation in the Fallon area. During years with above average precipitation, the Carson River flows to Carson Lake at the south end of the Carson Desert, Stillwater Marsh on the east-central side, and Carson Sink to the north. Carson Sink is a large salt flat during years of normal or below-normal precipitation, but during wet years, such as the period 1982-84, it becomes a large shallow lake fed by the Carson River, irrigation return flow, and overflow from the Humboldt River Basin (Rowe and Hoffman, 1990).

In the Carson Desert, $370 \mathrm{mi}$ of lined and unlined canals and laterals supply water, primarily to alfalfa fields (U.S. Bureau of Reclamation, 1986). Irrigation return flow is collected in about $350 \mathrm{mi}$ of open drains and flows northeast towards Stillwater and south to Carson Lake (Hoffman and others, 1990, p. 10). Because of the large amounts of irrigation drainage from the Newlands Project, the Fallon National Wildlife Refuge was established in 1931 and the Stillwater Wildlife Management Area and the Stillwater National Wildlife Refuge were established in 1948 (fig. 2). The State of Nevada manages a wildlife area near Carson Lake. Additional historical information for these wildlife areas is given by Thompson and Merritt (1988), Hallock and Hallock (1993), and Hoffman (1994).

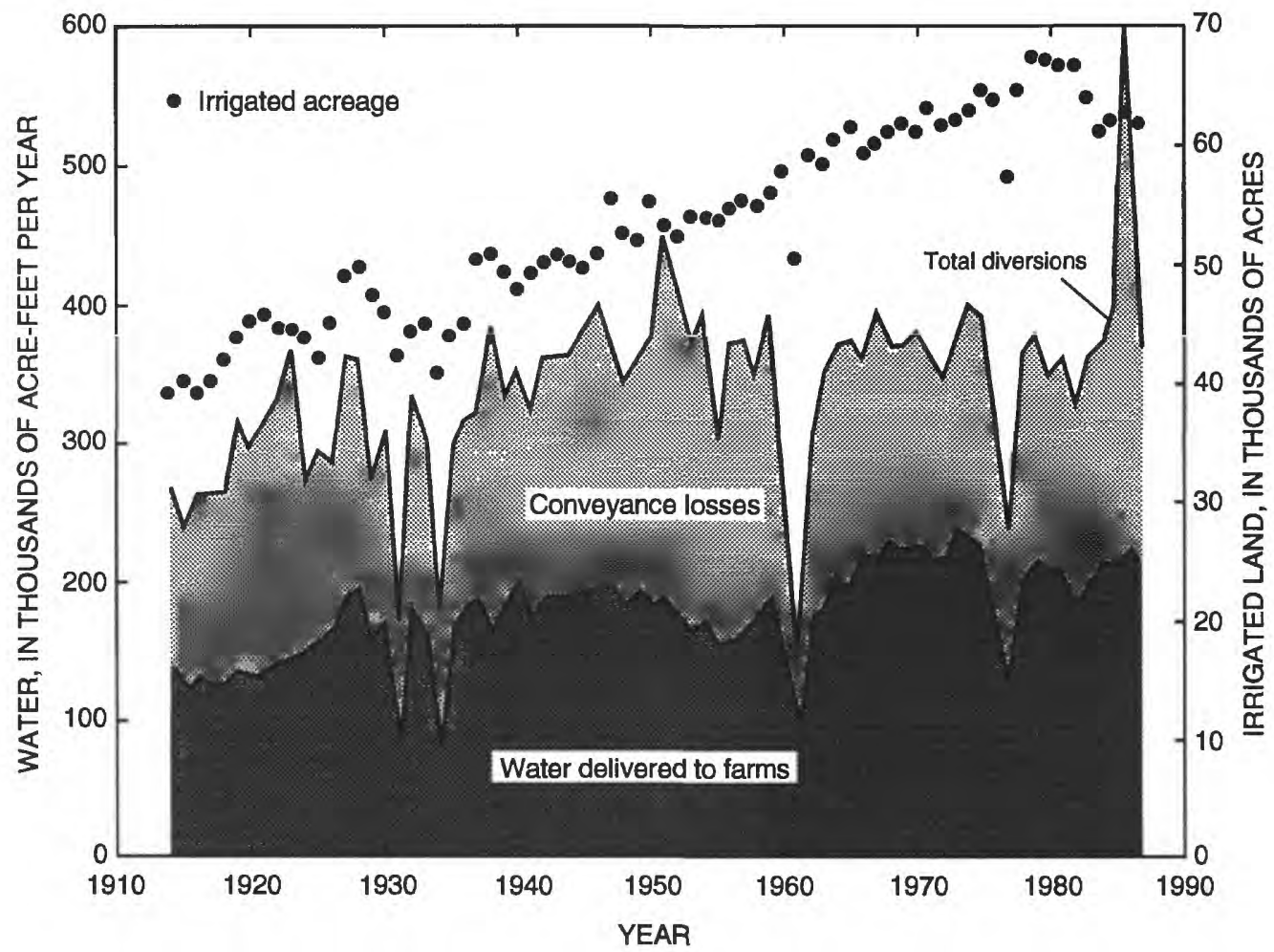

Figure 4. Estimated irrigated acreage, water diversions, and water delivered to farms in the Newlands Project, Carson Desert, and Fernley hydrogeographic areas, 1914-87. Conveyance loss is the difference between amount of water diverted and the amount delivered to fields. The total diversions compiled for 1986 include water that flowed over the flashboards in Lahontan Reservoir during a February flood; data for other years do not include such overflow. (From Welch and others, 1989, p. 19.) 


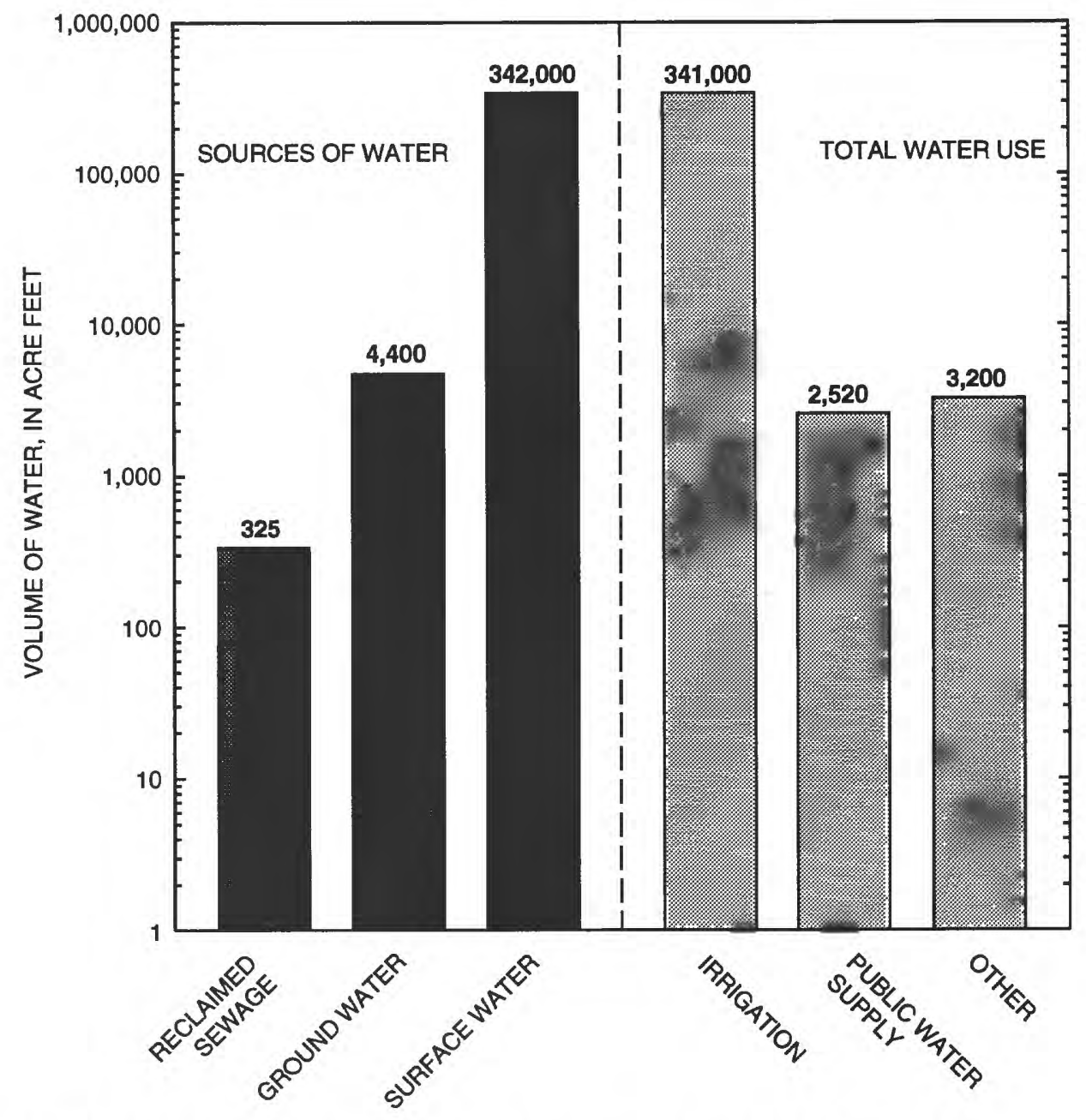

Figure 5. Volume of water from different sources and water use in Carson Desert during 1985. Data sources: U.S. Geological Survey National Water-Data Storage and Retrieval System (WATSTORE) and U.S. Geological Survey files, Carson City, Nev.

\section{Ground-Water Hydrology}

The ground-water system in the Carson Desert is complex. It consists of basin-fill, thermal, and basalt aquifers. The system has been investigated in the southern Carson Desert (Glancy, 1986), in the Stillwater Geothermal area (Morgan, 1982), and in the Soda Lakes-Upsal Hogback Geothermal area (Olmsted and others, 1984; Olmsted, 1985).

\section{Basin-Fill Aquifer Systems}

Glancy (1986, p. 6) divided the basin-fill aquifers into three aquifer systems-shallow, intermediate, and deep. The shallow aquifers extend from near land sur- face to depths of about $50 \mathrm{ft}$, except for the small areas where volcanic rocks crop out. The intermediate aquifers underlie the shallow aquifer systems and extend from $50 \mathrm{ft}$ to as much as $1,000 \mathrm{ft}$ below land surface. The deep aquifers are not well described. They underlie the intermediate aquifers, generally below depths of 500 to $1,000 \mathrm{ft}$, and may be as much as 8,000 -ft thick. The basin-fill sediments comprising these three aquifer systems were deposited during the Pleistocene and include several formations described by Morrison (1964). These deposits are the result of sedimentation in Pleistocene Lake Lahontan and eolian and fluvial movement of these sediments in the intervening stages when the lake was dry. 


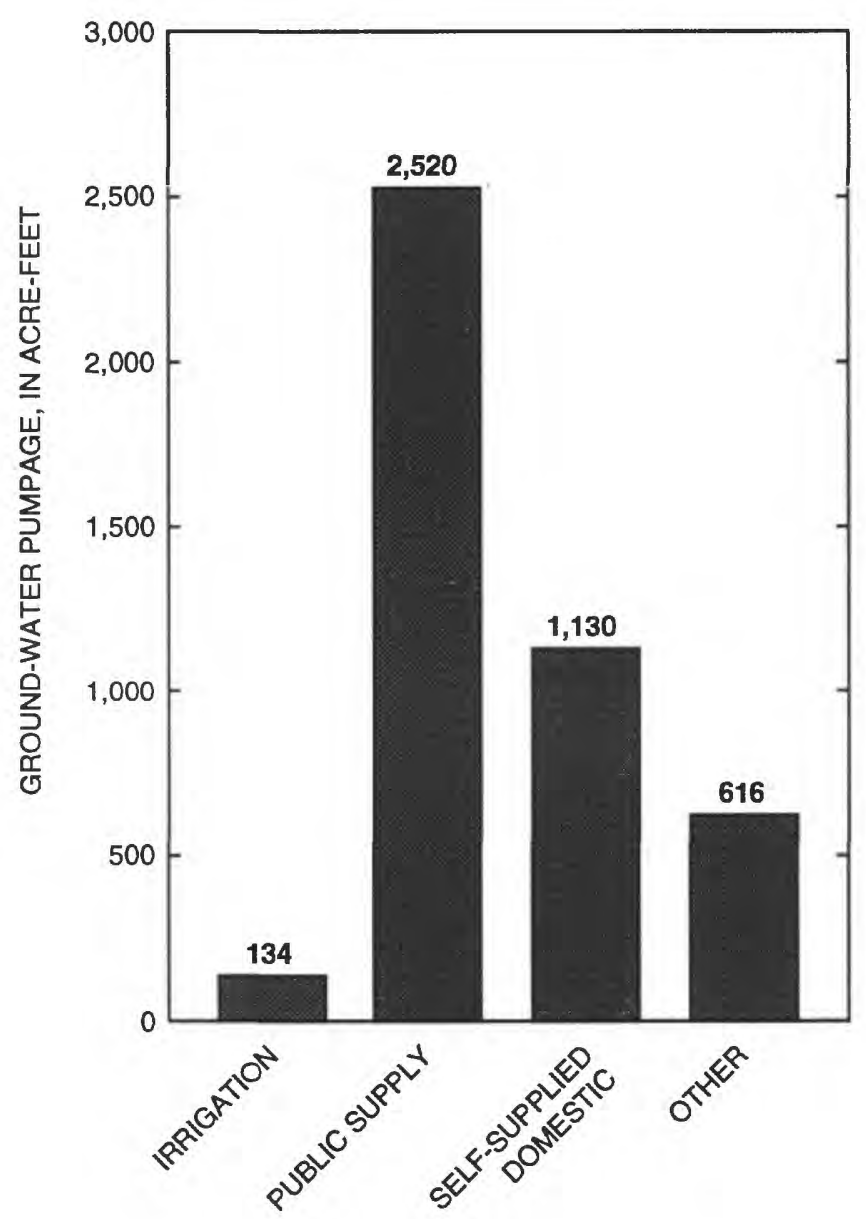

Figure 6. Pumpage and uses of water from aquifers in the Carson Desert during 1985. Data sources: U.S. Geological Survey National Water-Data Storage and Retrieval System (WATSTORE) and U.S. Geological Survey files, Carson City, Nev.

The basin-fill sediments mainly consist of interlayered beds of sand, silt, clay, and sparse stringers of gravel that were deposited in alluvial, lacustrine, and eolian environments. Individual strata are not areally extensive, with the possible exception of some lacustrine clay layers. The hydraulic properties of the deposits are variable over short lateral distances. Highly transmissive zones of gravel probably facilitate most of the ground-water flow in these aquifers.

The shallow aquifers are the source of water for many domestic and a few irrigation wells in the Carson Desert. The intermediate aquifers also are a source of water for domestic and irrigation uses, however, fewer wells are completed in the intermediate aquifers than in the shallow aquifers. The deep aquifers are not used except for a few deep exploration wells.

\section{Basalt Aquifer}

Several basalt aquifers are present beneath the Carson Desert. The principal source of water for the city of Fallon is derived from one of these aquifers beneath the Fallon area (Glancy, 1986). This aquifer is referred to as the basalt aquifer in this report. During the period 1941-78, about 35,000 acre-ft of water was pumped from the aquifer (Glancy, 1986, table 6). The basalt aquifer is a northeast-trending, asymmetrical mushroom-shaped body. At Rattlesnake Hill, the basalt is exposed at the surface; at site 52, about $4.5 \mathrm{mi}$ to the northeast, the top of the basalt is several hundred feet below land surface. Figure 7 shows the areal extent of the aquifer at about $1,000 \mathrm{ft}$ below land surface, based on limited drilling and geophysical modeling of resistivity data (Glancy, 1986).

The direction of ground-water movement in the basalt aquifer is not known. Hydraulic gradients in the aquifer are nearly flat (Glancy, 1986, p. 15-16), however, there may be a slight gradient toward the northeast. On November 29,1978 , the altitude of the potentiometric surface in four wells near the center of Fallon was 3,921.7 ft and the altitude in two wells about $6 \mathrm{mi}$ to the north northeast was $3,920.5 \mathrm{ft}$.

The basalt appears to be a heterogeneous mass that extends both laterally and vertically and varies lithologically from dense impermeable lava flows to highly permeable zones of loosely consolidated scoriaceous cinders (Glancy, 1986, p. 15). The lava flows probably are fractured and the fracture systems can interconnect with the highly permeable zones of cinders.

The basalt aquifer is highly transmissive. Transmissivity estimated from pumping tests ranges from 4,100 to $170,000 \mathrm{ft}^{2} /$ day (Glancy, 1986, table 3). Glancy (1986, p. 15) estimated that the storage coefficient for the confined basalt aquifer does not exceed 0.001 .

\section{Thermal Aquifer Systems}

Thermal areas in the Carson Desert have been described in detail by several investigators (Garside and Schilling, 1979; Sibbett, 1979; Morgan, 1982; Olmsted and others, 1984; Olmsted, 1985). Thermal features in the Carson Desert include the Stillwater Geothermal area, the Soda Lakes-Upsal Hogback Geothermal area, and the West Carson Lake and Salt Wells basin geothermal areas. For the purposes of this report, thermal aquifers are defined as aquifers that contain water at temperatures of $30^{\circ} \mathrm{C}$ or higher. 


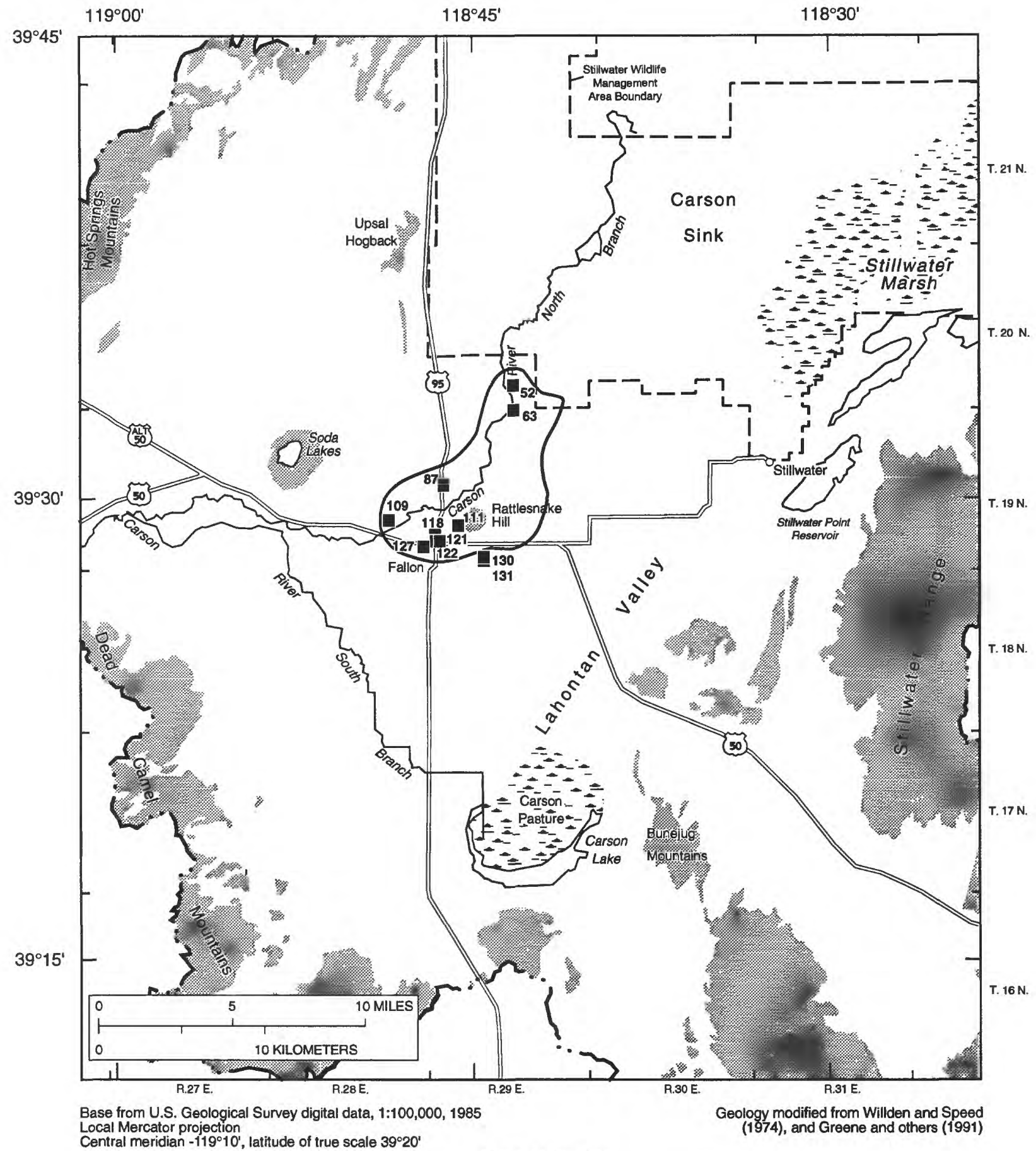

EXPLANATION

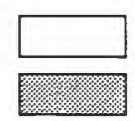

BASIN-FILL DEPOSITS

CONSOLIDATED ROCKS

-.. HYDROGRAPHIC AREA BOUNDARY

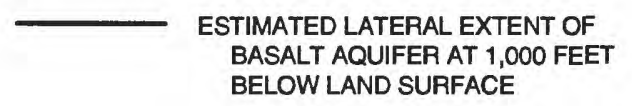

63
SAMPLING SITE IN BASALT AQUIFER, AND SITE NUMBER

Figure 7. Extent of the basalt aquifer at a depth of 1,000 feet beneath the Fallon area based on drillers' logs and electrical resistivity measurements. Data from Glancy (1986, p. 14). 
The thermal systems result from deep circulation of meteoric water. According to the conceptual model of Olmsted (1985), cold meteoric water moves downward through a fault or fault system to a hot permeable zone within consolidated rocks. As the water moves laterally through the permeable zone, it is heated. Hot water leaves the aquifer and rises along a fault or fault system. Thermal water in the Stillwater area discharges into a Tertiary sand aquifer, but some water rises to the overlying Quaternary alluvial and lacustrine deposits (Morgan, 1982, p. 83). Discharge of hot water at the surface is prevented by absence of fault conduits in the fine-grained lake deposits despite the strong upward gradients. High heat flow in the Great Basin may be attributed to upward convective transport in the Earth's upper mantle (Lachenbruch and Sass, 1978, p. 243).

The Soda Lakes thermal system probably has a different recharge mechanism from that of the Stillwater thermal system (Olmsted and others, 1984, p. 128). On the basis of the stable-isotopic composition of the thermal water, possible sources of recharge were water in Lake Lahontan or the Carson River that was affected by evapotranspiration. These possible sources indicate that recharge is through the basin-fill deposits rather than by flow along a fault zone.

Hot water from thermal wells is used to heat some homes in the Stillwater area. Electrical power is generated using hot water and steam from wells in the Stillwater and Soda Lakes thermal areas.

\section{Mineralogic Composition of Basin-Fill Sediments and the Basalt Aquifer}

The mineralogic composition of sediments in parts of the Carson Desert has been described by Lico and others (1986 and 1987). The composition of the sediment from the shallow basin-fill aquifers reflects the igneous origin of the source rocks (mostly basalt) in the surrounding mountains. The sediments are composed mostly of plagioclase feldspar (anorthite and albite), volcanic-lithic fragments, quartz, sedimentary lithic fragments, and potassium feldspar. Calcite, clay minerals (montmorillonite, illite, and chlorite), and zeolites (heulandite and clinoptilolite) are secondary minerals in the aquifer material. Minerals in the shallow basin-fill aquifer in the Stillwater Wildlife Management Area (northeastern Carson Desert) are described by Lico (1992). Grains include quartz, plagioclase (mostly oligoclase, andesine, and labradorite), calcite, potassium feldspar, basaltic to andesitic lithic fragments, and biotite, with minor amounts of pyroxene and hornblende. Alteration of plagioclase to illite, sericite, and chlorite is common, as is alteration of biotite to chlorite. Chlorite is an alteration product in the groundmass of lithic fragments and in grains of hornblende and pyroxene. Calcite is a secondary phase precipitated on shell fragments and as caliche layers that were formed in the unsaturated zone.

The mineralogic composition, including original detrital minerals and authigenic phases, of an aquifer is important in constraining any conceptual or numerical model of the interaction between ground water and the aquifer matrix. Important observations include whether precipitation or dissolution of mineral phases has occurred and the presence of alteration features on detrital grains. In some mineral samples, it is difficult to distinguish whether features were formed in place or at some other location and transported to the Carson Desert.

Core samples were collected from the shallow basin-fill aquifers adjacent to well screens with a splitspoon sampler. The mineralogic composition of the deposits analyzed for this study indicate that they were derived from mixed plutonic, volcanic, metavolcanic, and metasedimentary terranes. Most of the plutonic lithic grains are quartz monzonite; lithic grains of granodiorite and granite are present in lesser amounts. Mafic volcanic, metadacite, and metasandstone and siltstone are the most abundant volcanic, metavolcanic, and metasedimentary lithic fragments, respectively. Monomineralogic grains are plagioclase (primarily labradorite and andesine), quartz, potassium feldspar, hornblende, augite, biotite, and magnetite (possibly ilmenite). Quartz grains are unaltered and commonly have thin discontinuous coatings of chlorite or hematite (rarely) precipitated on grain boundaries. Plagioclase grains commonly are altered to chlorite along cleavage planes and grain surfaces. Sericite is the second most common alteration product and is abundant on some grains. Vacuoles filled with chlorite or sericite are abundant in plagioclase grains. Potassium feldspar is slightly altered with thin coatings of chlorite and sericite on grains.

Hornblende and augite grains are either unaltered or slightly altered to chlorite along their edges. Some hornblende grains have rough or jagged grain boundaries, possibly indicative of dissolution. Biotite grains are moderately to strongly altered to chlorite. Opaque mineral grains (magnetite and ilmenite) commonly have thin hematite rims. Some 
of the chlorite and sericite is present as coatings on the outer surfaces of grains, indicating that this alteration occurred after the mineral and other lithic sediment particles were transported to the Carson Desert.

Basaltic lithic fragments are the most common volcanic grains in sediment of the Carson Desert. The groundmass of these grains commonly is slightly altered to chlorite. Plagioclase laths show minor illitic or sericitic alteration. Augite is the most abundant mafic mineral and has slight chloritic alteration. Minor amounts of magnetite or ilmenite are present and have thin hematite rims. Some siliceous tuff fragments consist mostly of slightly chloritic devitrified glass. Metadacite in small fragments typically has a moderately chloritic groundmass, strongly sericitic feldspar crystals, and a minor amount of unaltered epidote. Most basalt fragments are altered in a similar manner to those described above.

Calcareous silt, clay, and carbonate lithic grains make up a small part of the sediment in the shallow aquifers. Calcitic and phosphatic fossil fragments are present in these sediments and show no evidence of dissolution or precipitation.

Clay minerals are abundant in the sediment from the shallow basin-fill aquifers. Montmorillonite (beidellite) is the most common clay and illite the next most abundant. Lesser amounts of chlorite and kaolinite also are present.

The mineralogic composition of the basalt aquifer was determined by $\mathrm{X}$-ray diffraction analysis and thin-section petrography. The bulk of the basalt is composed of zoned plagioclase (albite and intermediate anorthite), sanidine, and augite. On visual inspection of the basalt rock, secondary minerals were seen precipitated on fracture and vesicle surfaces. Samples of this material were scraped off the rock and the composition determined by X-ray diffraction analysis. Calcite (with approximately 2.5 mole percent magnesium) was the major mineral present. Small amounts of quartz, phillipsite (a potassium calcium zeolite), and a clay minerals also were identified. Alteration of the basalt aquifer matrix consists of slight chloritization of pyroxene (augite) crystals and the groundmass. Plagioclase laths have minor illitic or sericitic alteration along cleavage planes. The edges of iron-bearing minerals (magnetite or ilmenite) commonly are hematitic.

\section{Movement of Ground Water and Isotope Hydrology}

The principal source of recharge to the basin-fill aquifer systems in the southern Carson Desert is infiltration from the system of river channels, canals, and ditches that crisscross the desert (Glancy, 1986).

Other sources include infiltration of irrigation water, local ponding of precipitation in low-lying areas after intense storms (generally in surrounding nonirrigated areas; Olmsted, 1985, p. 25), and precipitation in mountains surrounding the basin.

Recharge to the basalt aquifer is from surrounding sediments. Glancy (1986, p. 26) concluded that most of the recharge is from the intermediate and shallow aquifers. The hydraulic gradient is such that water can move into the basalt aquifer from the intermediate aquifers in the southwestern part of the basalt aquifer and back into the intermediate aquifers near the northeastern part of the basalt aquifer (Glancy, 1986, fig. 10). Some recharge to the basalt aquifer may be from irrigation canals near Rattlesnake Hill, where the basalt is exposed at the surface.

In much of the western and southwestern parts of the Carson Desert, the hydraulic gradient between the shallow and intermediate aquifers is downward and water moves into the underlying aquifers. The overall area where there is potential for downward movement exceeds $100 \mathrm{mi}^{2}$ (Glancy, 1986, p. 54). In the eastern and southern parts of the Carson Desert, the hydrologic gradient is upward and water moves from the intermediate aquifers to the shallow aquifers.

In both the shallow and intermediate aquifers, the altitude of the potentiometric surface ranges from about 4,000 ft above sea level in the western part of the study area to about 3,900 ft in the eastern part (Glancy, 1986, p. 42 and 53). The direction of ground-water movement in the shallow and intermediate aquifers generally is northeastward toward the Carson Sink and Stillwater Marsh and southeastward toward Carson Lake and Fourmile and Eightmile Flats.

The average horizontal hydraulic gradient is about $7.5 \mathrm{ft} / \mathrm{mi}$ in the shallow aquifers (Glancy, 1986, p. 38) and about $6.5 \mathrm{ft} / \mathrm{mi}$ in the intermediate aquifers (Glancy, 1986, p 51). Glancy (1986) estimated specific capacity values for about 430 wells in the shallow aquifers and 15 wells in the intermediate aquifers. The greatest specific capacities, about $70 \mathrm{gal} / \mathrm{min} / \mathrm{ft}$ of drawdown, are in the shallow aquifers on the western side of the area, where the Carson River enters the 
basin. Specific capacity in the intermediate aquifers ranges from 0.5 to $12 \mathrm{gal} / \mathrm{min} / \mathrm{ft}$ of drawdown, which is similar to that in most of the shallow aquifers.

The principal mechanism of natural discharge from the shallow aquifers is evapotranspiration. Some discharge also results from pumpage, open surface drains, and ditches 10 - to 15 -ft deep that drain shallow ground water from irrigated areas. This irrigation-return flow is delivered to the Stillwater and Carson Lake Wildlife Management Areas for use in maintaining wildlife habitat.

\section{Hydrogen and Oxygen Isotopes}

Stable isotopes of water (hydrogen and oxygen) can be used to aid in the identification of the origin and thus the recharge mechanism for certain ground-water systems. A water molecule has variable concentrations of the stable isotopes of hydrogen and oxygen. Hydrogen has two stable isotopes with masses of 1 (protium) and 2 (deuterium); oxygen has two stable isotopes with masses of 16 and 18. The stable-isotope composition of water may be used as an indicator of the source of recharge to ground-water systems because, in general, the stable-isotope composition of nonthermal (less than $30^{\circ} \mathrm{C}$ ) water is not affected by processes other than evaporation. Stable hydrogen and oxygen isotope compositions are expressed relative to a standard (Vienna Standard Mean Ocean Water) in units of parts per thousand or 'permil' (Fritz and Fontes, 1980, p. 11). Because surface water and atmospheric precipitation that provide recharge to ground-water systems in the Carson Desert are "lighter" than the standard mean ocean water, the isotope composition (or permil) values are all negative. When comparing water of differing composition, the lighter water (water containing less of the heavier isotope) will have a more negative permil value than the heavier water. The distribution of deuterium in ground water of the Carson Desert is shown in figure 8. The areal distribution of deuterium shows that heavier deuterium values correspond to discharge areas near Stillwater and Carson Lake in the shallow aquifers, but that there is no apparent areal relation for deuterium in the intermediate aquifers.

The stable-isotopic composition of water in the Carson Desert is shown in figure 9. There are two isotopic groups. The first group $(A)$ consists mostly of water from wells in the intermediate, basalt, and thermal aquifers, and from some wells in the shallow aquifers in nonirrigated areas. This group (group $A$ in fig. 9) follows an evaporation trend line originating in isotopically light water in the intermediate and basalt aquifers near Fallon and ending as highly evaporated water in the shallow aquifers at discharge areas near Carson Lake and Stillwater. Ground water from wells in the intermediate aquifers in the Upsal Hogback area are of an intermediate isotopic composition along this evaporation trend line.

The other isotopic group (group $B$ in fig. 9) consists of water from wells in the shallow aquifers in areas that are irrigated and from two wells tapping the intermediate aquifers near Lahontan Reservoir. Water in this group has a composition that lies along a mixing line between the endmembers for Carson River and slightly evaporated Truckee Canal water as represented by samples from the Truckee River at Nixon. This composition is shown in figure 9. Many samples are offset from this mixing line because of evaporation of different mixtures of endmembers during transport and application of the water for irrigation. No single evaporation trend line can be defined for these samples because of the variable composition of the irrigation water. The isotopic composition of the irrigation water (from Lahontan Reservoir) can vary because of (1) differing amounts of Carson and Truckee River waters, (2) the degree of evaporation of Truckee River water in the Truckee Canal, and (3) the amount of evaporation in the irrigation distribution system before recharge to the shallow aquifers. Only one analysis for stable isotopes of hydrogen and oxygen is available for water from a site just downstream from Lahontan reservoir on the Carson River-the delta deuterium is -103 permil and the delta oxygen-18 is -13.7 permil. This sample has a similar composition to other Carson River samples collected at upstream sites.

Thus, water in the shallow aquifers in the Carson Desert has two origins. Ground-water in irrigated areas evolves isotopically from a mixture of present-day Carson and Truckee Rivers water. Water in the shallow aquifers in nonirrigated areas (Carson Pasture and Stillwater Marsh) evolves isotopically from water in the intermediate and basalt aquifers.

Water in the intermediate and basalt aquifers in the Fallon area is generally lighter in hydrogen isotopes than water in the present-day Carson and Truckee Rivers. Evaporation makes water isotopically heavier, thus, present-day Carson and Truckee River water cannot evolve into the water now found in the intermediate and basalt aquifers. It follows that water supplied for irrigation is not the principal source of water presently in the intermediate and basalt aquifers. 


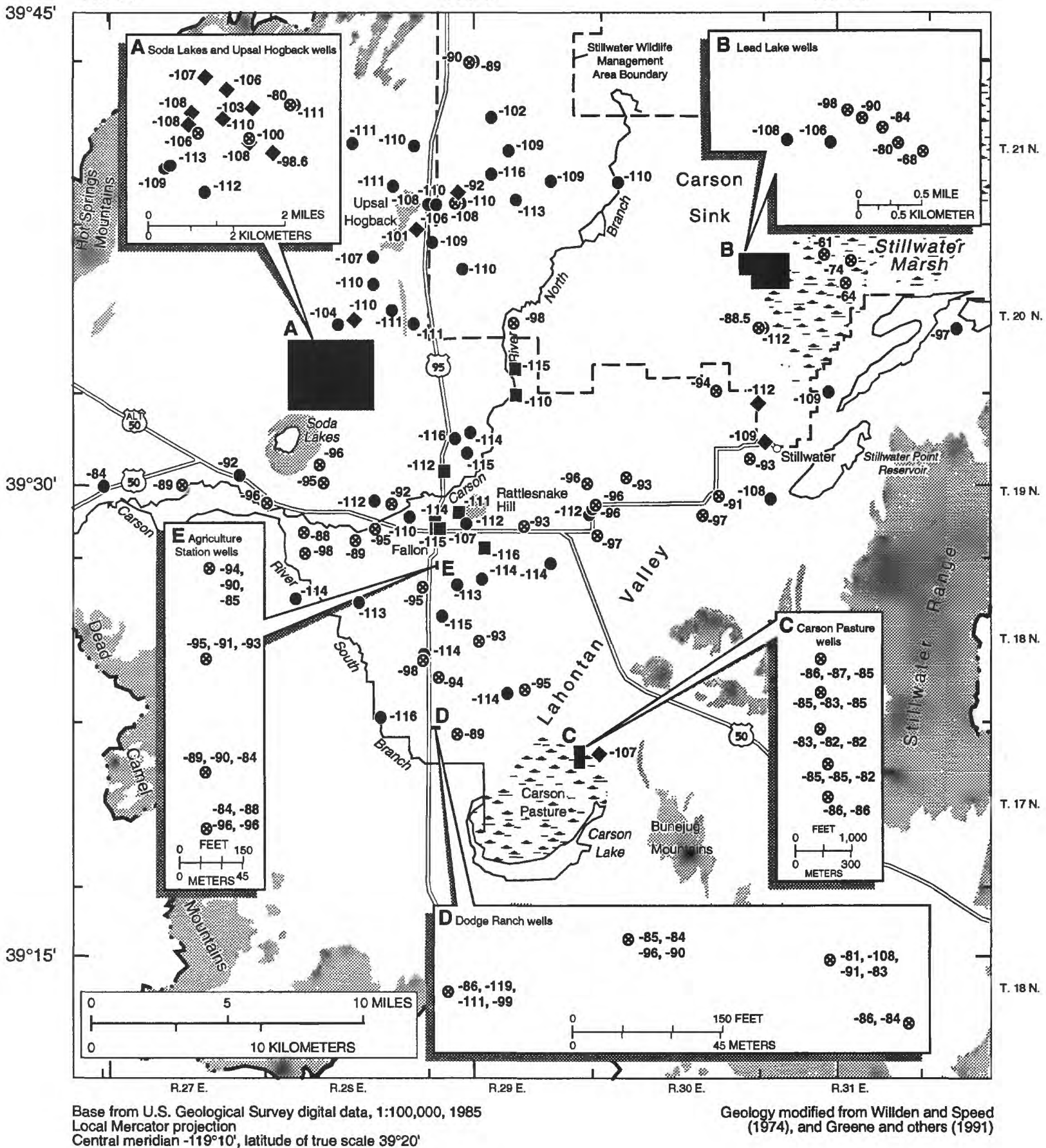

\section{EXPLANATION}

\begin{tabular}{ll}
\hline & BASIN-FILL DEPOSITS \\
CONSOLIDATED ROCKS \\
$-\cdots-$ HYDROGRAPHIC AREA BOUNDARY
\end{tabular}

$\begin{array}{ll} & \begin{array}{c}\text { SAMPLING SITE - Number } \\ \text { is deuterium value, in permll } \\ \text { Shallow aquifer }\end{array} \\ -89 & \text { Intermediate aquifer } \\ -110 & \text { Basalt aquifer } \\ -116 & \text { Thermal aquifer }\end{array}$

Figure 8. Stable-isotope composition of hydrogen (deuterium) in ground water at selected sites. 


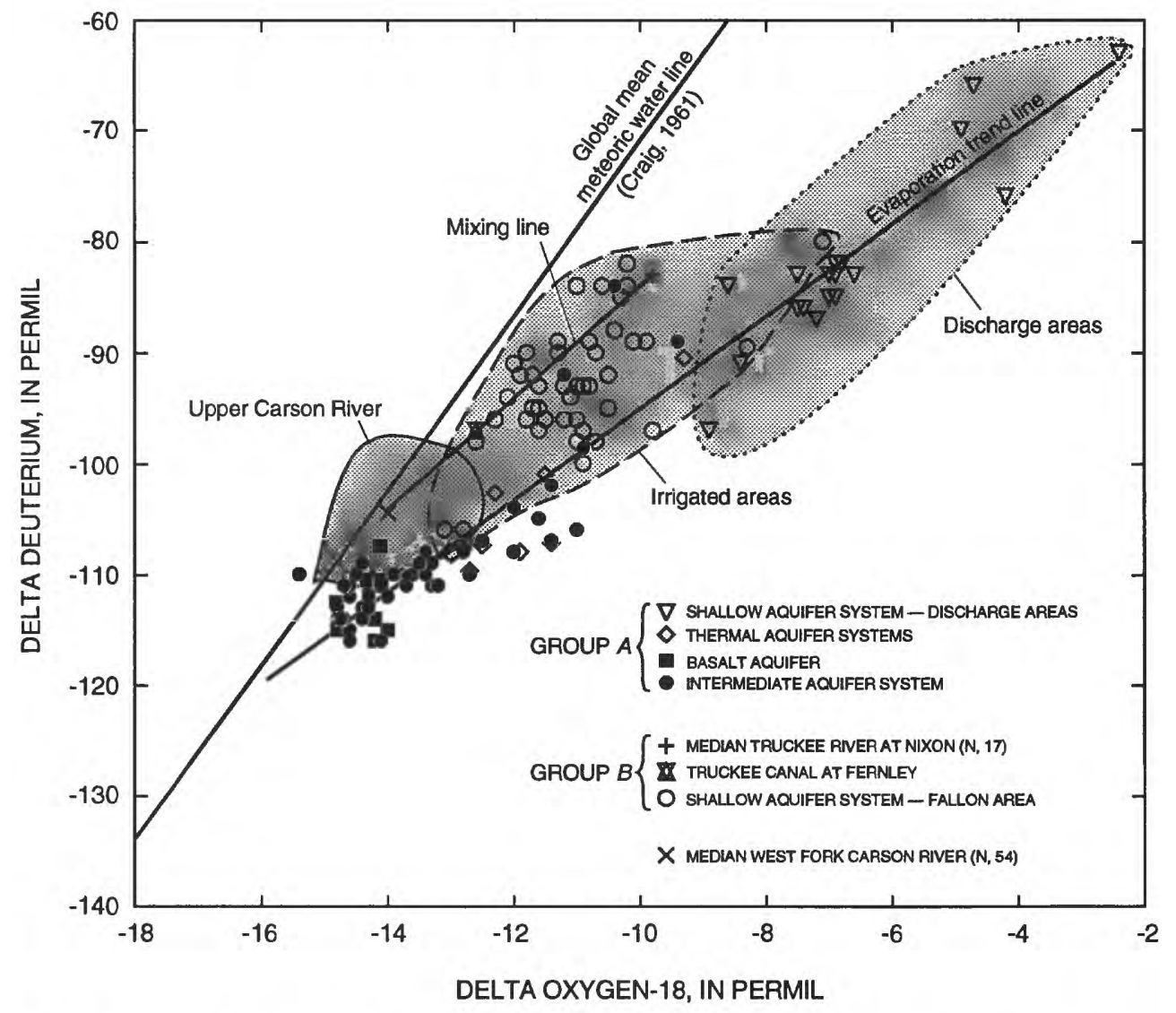

Figure 9. Relation between the stable-isotope composition of hydrogen (deuterium) and oxygen in ground water in Carson Desert. ( $N$, number of samples.)

The presence of tritium in water from the basalt aquifer indicates that it has received some recent recharge. The most probable sources are large irrigation canals near where the basalt is exposed at the surface or is at shallow depths. The exact proportion of water in the basalt aquifer that results from recharge from canals is not known and cannot be calculated with present data.

There are several possible sources for the water presently found in the intermediate and basalt aquifers. Stable isotopes of water do not conclusively support any one source of water. The water in these aquifers could have originated in the Carson River before construction of Lahontan Reservoir. Evaporation from the lake surface makes the present-day river water isotopically heavier than before construction of the reservoir. However, even present-day water in the upper reaches of the river in the Sierra Nevada is isotopically heavier than water in the intermediate and basalt aquifers, making this explanation unlikely.
Water in the aquifers could result from mixing of Carson River water and local precipitation. Water from springs in the Bradys Hot Springs area (about $25 \mathrm{mi}$ northwest of Fallon) and the Stillwater Range (about 25 mi east of Fallon) is isotopically lighter than the ground water in the intermediate and basalt aquifers (Welch and Preissler, 1986; Jacobson and others, 1983). Also, water from springs in the Truckee Range west of Fernley (about $25 \mathrm{mi}$ west of Fallon) has a similar isotopic composition to water from the intermediate and basalt aquifers (Rowe and others, 1991). Considering the high potential evapotranspiration on the basin floor, recharge from local precipitation would have to be in the mountains surrounding the basin.

Another possible source for water in the intermediate and basalt aquifers could be recharge during the Pleistocene before Lake Lahontan was desiccated (about 4,000 years ago). Carbon- $14\left({ }^{14} \mathrm{C}\right)$ ages for water from some of the wells are old enough to support this origin. 
Water presently in the intermediate and basalt aquifers probably is the result of recharge in the past, before completion of the Newlands Project. Water from the Carson River probably was isotopically lighter in the past. Observations of former levels of Pyramid Lake and cirque glacier reformation in the Sierra Nevada indicate that the climate in the Lahontan area has been wetter and dominated by winter precipitation from about 600 to 50 years before present (late Holocene; Davis, 1982). Presumably, precipitation during this period was isotopically lighter and more recharge would have occurred then because prehistorically large flows on the Carson River discharged to the Carson Desert. The possibility that the ground water was recharged within the past several hundred years is supported by ${ }^{14} \mathrm{C}$ ages for water in some of the wells.

\section{Tritium}

Tritium is a radioactive isotope of hydrogen $\left({ }^{3} \mathrm{H}\right)$ that may be part of the water molecule. Tritium has a half life of 12.33 years (Friedlander and others, 1981), so it can be used as an indicator of recent ground-water age. Age in this study is the time the water has been isolated from the atmosphere. This information can be helpful in identifying areas where ground water has recently been exposed to the atmosphere. Prior to above-ground detonation of thermonuclear weapons in the northern hemisphere, which began in 1952, tritium content in the atmosphere was produced by the impact of cosmic neutrons on nitrogen nuclei in the upper atmosphere, resulting in a steady-state concentration of about 25 pCi/L in ground water (Fontes, 1980, p. 79). Radioactive decay of the tritium during a period of 57 years ( 4.6 half lives) results in a present-day tritium level of less than $1 \mathrm{pCi} / \mathrm{L}$. Thus, ground water containing less than $1 \mathrm{pCi} / \mathrm{L}$ of tritium today (1992) is probably older than 57 years. Major releases of tritium to the atmosphere from nuclear testing resulted in tritium concentrations greater than $10 \mathrm{pCi} / \mathrm{L}$ since 1954. Higher concentrations in precipitation producing present-day concentrations greater than $100 \mathrm{pCi} / \mathrm{L}$ occurred in 1958-59 and 1962-69. Mixing of water with different concentrations of tritium can produce intermediate values. On the basis of this broad outline, the tritium data for Carson Desert is interpreted by using the following general guidelines: (1) ground water having tritium concentrations less than $1 \mathrm{pCi} / \mathrm{L}$ is older than 57 years; (2) values ranging from 1 to $10 \mathrm{pCi} / \mathrm{L}$ are either a mixture of pre- and post-detonation water or an indication of water ranging in ages from about 38 to 57 years; (3) concentrations greater than $10 \mathrm{pCi} / \mathrm{L}$ are younger than 38 years or may be a mixture of pre- and post-nuclear detonation water; and (4) concentrations greater than $100 \mathrm{pCi} / \mathrm{L}$ are a result of major nuclear releases noted above and thus are younger than 38 years.

The distribution of tritium concentrations in water samples from the aquifers in the Carson Desert is shown in figure 10. Tritium analyses for this NAWQA project (table 1$)$ have two reporting levels $(0.3$ and $16 \mathrm{pCi} / \mathrm{L})$ and were made at different laboratories.

Water in the shallow aquifers in irrigated areas has tritium concentrations ranging from 39 to $93 \mathrm{pCi} / \mathrm{L}$ (table 1). Modern water (recently in contact with the atmosphere) is within this range, and because surface water is the principal source of recharge to the shallow aquifers, these values are expected. Two wells in the intermediate aquifers nearest Lahontan Reservoir (sites 88 and 94) have tritium concentrations of 90 and $67 \mathrm{pCi} / \mathrm{L}$, respectively, indicating rapid recharge from either the shallow aquifers or surface-water sources. Values for the stable isotopes in water also indicate these two sites are recharged by the shallow aquifers or surface water. Water from three wells completed in the shallow aquifers near Carson Lake has tritium concentrations less than $16 \mathrm{pCi} / \mathrm{L}$, which indicates that the water is at least 20 years old or that it has had little mixing with post-nuclear detonation water. This observation supports the premise that upward flow from the intermediate aquifers is recharging the shallow aquifers in this area.

Water samples from all wells in the intermediate aquifers, except two in the western part of the Carson Desert nearest Lahontan Reservoir, have tritium concentrations consistent with the hypothesis that recharge occurred more than 57 years ago. Tritium concentrations less than $16 \mathrm{pCi} / \mathrm{L}$ can be produced by mixing pre- and post-nuclear detonation waters, water recharged during 1954, 1956-58, 1960-61, or 1969 to the present (1992), or water that was recharged prior to nuclear testing. Water from all wells in the intermediate aquifers analyzed using the lower detection limit method has tritium concentrations less than $1 \mathrm{pCi} / \mathrm{L}$, indicating that recharge occurred more than 57 years ago. All tritium analyses using the higher detection limit, except those for samples from sites 88 and 94 , have values less than the reporting limit $(16 \mathrm{pCi} / \mathrm{L})$ which, while not proof, is consistent with ground-water ages greater than 57 years. Water from wells at sites 97 and 150 (fig. 3 and table 1 ) has values of 0.3 and $0.5 \mathrm{pCi} / \mathrm{L}$ and sites 74 and 95 . Glancy (1986) reported tritium concentrations of less than $0.3 \mathrm{pCi} / \mathrm{L}$. 


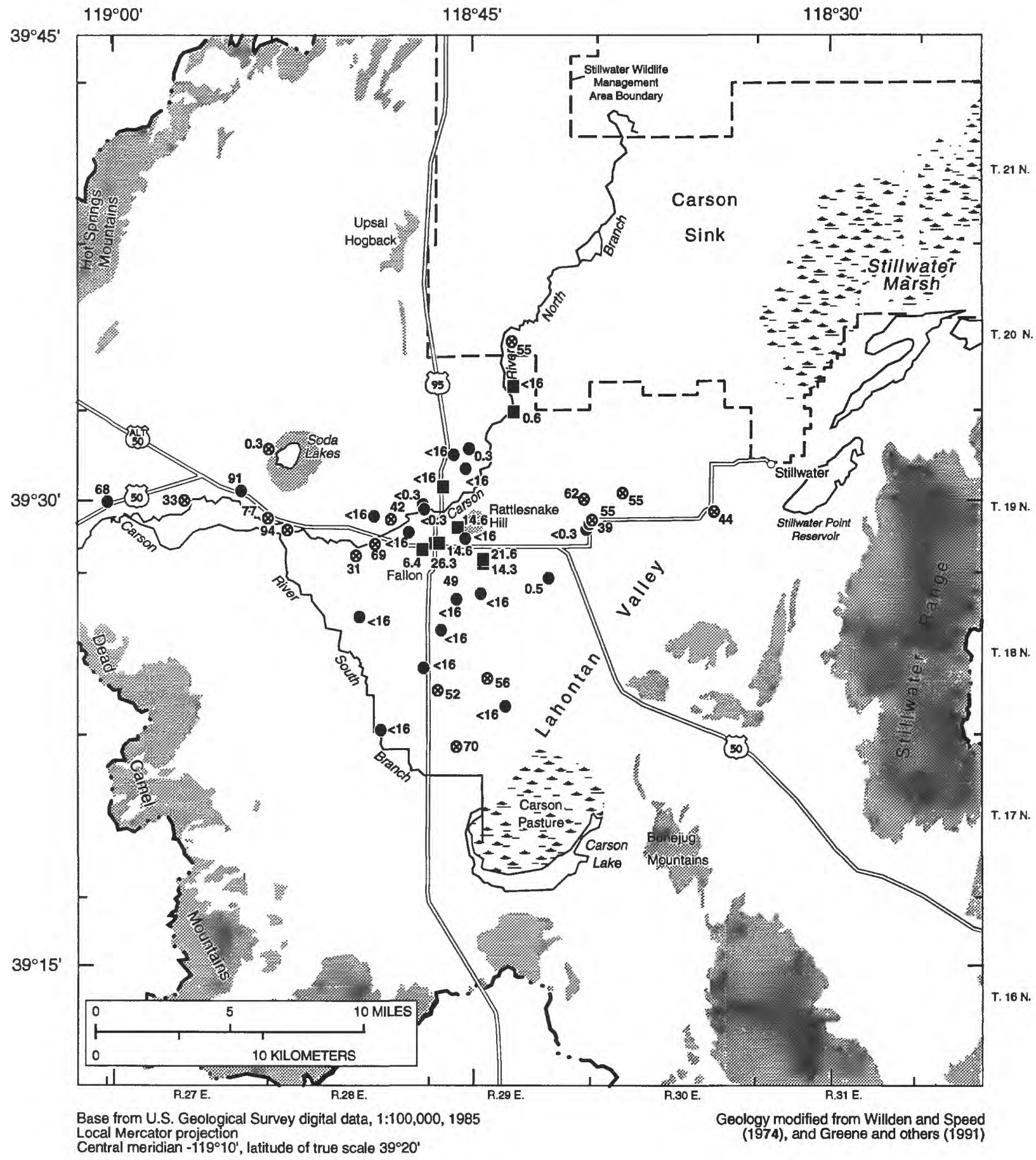

EXPLANATION

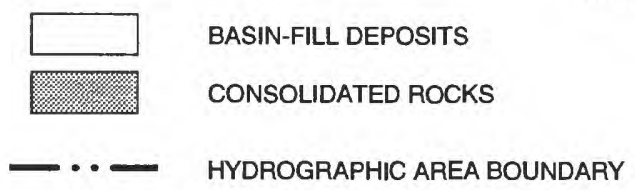

SAMPLING SITE - Number Is tritium concentration, in picocuries per liter

(2) 70 Shallow aquifer

0.5 Intermedlate aquifer

6.4 Basalt aquifer

Figure 10. Tritium concentrations in ground water at selected sites. 
Table 1. Activities of tritium and carbon-14 and estimated ages of ground water from selected sites in the Carson Desert

[Carbon-13 values are relative to carbonate-mineral belemnite fossil from Cretaceous Peedee Formation of South Carolina. Analyses made in 1978 are from Glancy (1986).

Abbreviations and symbol: permil, parts per thousand; $\mathrm{PMC}$, percent modern carbon; $\mathrm{pCi} / \mathrm{L}$, picocuries per liter; --, data not available]

\begin{tabular}{|c|c|c|c|c|c|c|}
\hline $\begin{array}{c}\text { Site } \\
\text { number } \\
\text { (fig. 3) }\end{array}$ & Date & $\begin{array}{c}\text { Carbon-13 } \\
\text { (permil) }\end{array}$ & $\begin{array}{c}\text { Carbon-14 } \\
\text { (PMC) }\end{array}$ & $\begin{array}{l}\text { Tritium } \\
\text { (pci/l) }\end{array}$ & $\operatorname{Lab}^{1}$ & $\begin{array}{l}\text { Estimated age } \\
\text { of ground water } \\
\text { (years) }\end{array}$ \\
\hline \multicolumn{7}{|c|}{ Shallow aquifers } \\
\hline 107 & 03-09-89 & -11.3 & -- & 42 & DRI & -- \\
\hline 108 & $04-19-89$ & -13.4 & -- & 55 & USGS & -- \\
\hline 110 & $04-19-89$ & -14.1 & -- & 39 & USGS & -- \\
\hline 113 & $02-23-89$ & -12.0 & -- & 93 & DRI & -- \\
\hline 164 & $08-30-89$ & -- & -- & 44 & USGS & -- \\
\hline 165 & $03-07-89$ & -11.6 & -- & 51 & DRI & -- \\
\hline 189 & $03-08-89$ & -14.0 & -- & 70 & DRI & -- \\
\hline 191 & $01-18-89$ & -- & -- & $<16$ & DRI & -- \\
\hline 192 & $01-17-89$ & -- & -- & $<16$ & DRI & -- \\
\hline 204 & $01-20-89$ & -- & -- & $<16$ & DRI & -- \\
\hline \multicolumn{7}{|c|}{ Intermediate aquifers } \\
\hline 74 & $04-25-89$ & -9.90 & 18.3 & $<0.3$ & USGS & 7,700 \\
\hline 75 & 03-01-89 & -11.4 & 69.4 & $<16$ & DRI & -- \\
\hline 82 & $05-31-89$ & -11.6 & 73.4 & $<16$ & DRI & 1,100 \\
\hline 88 & $02-28-89$ & -12.2 & 85.3 & 90 & DRI & modern \\
\hline 94 & $02-28-89$ & -11.0 & 89.6 & 67 & DRI & modern \\
\hline 95 & 03-08-78 & -11.0 & 61.7 & $<0.3$ & USGS & 1,400 \\
\hline 97 & $03-08-78$ & -10.7 & 86.5 & .3 & USGS & 1,200 \\
\hline 104 & $04-18-89$ & -12.5 & -- & $<16$ & DRI & - \\
\hline 115 & $03-07-89$ & -12.2 & 88.6 & $<16$ & DRI & modern \\
\hline 119 & $02-22-89$ & -12.1 & 76.9 & $<16$ & DRI & modern \\
\hline 150 & $05-31-89$ & -8.30 & -- & .5 & USGS & -- \\
\hline 151 & 03-08-89 & -8.50 & 35.3 & $<16$ & DRI & 3,200 \\
\hline 152 & $04-20-89$ & -10.7 & 62.4 & $<16$ & DRI & 1,600 \\
\hline 157 & $01-27-89$ & -13.2 & 60.5 & $<16$ & DRI & 1,200 \\
\hline 158 & $04-20-89$ & -8.80 & 39.5 & $<16$ & DRI & 3,100 \\
\hline 161 & $04-20-89$ & -8.50 & 40.8 & $<16$ & DRI & 2,700 \\
\hline 167 & $04-21-89$ & -10.1 & 13.2 & $<16$ & DRI & 7,300 \\
\hline 169 & $05-31-89$ & -6.30 & 18.1 & $<16$ & DRI & 6,300 \\
\hline \multicolumn{7}{|c|}{ Basalt aquifer } \\
\hline 52 & 03-09-89 & -8.20 & 15.4 & $<16$ & DRI & 8,100 \\
\hline 63 & $07-19-78$ & -6.89 & 30.2 & .6 & USGS & 3,600 \\
\hline 87 & $02-28-78$ & -8.72 & 34.1 & 2.6 & USGS & 4,400 \\
\hline 87 & 03-02-89 & -8.40 & 35.6 & $<16$ & DRI & 3,800 \\
\hline 111 & $03-01-89$ & -9.10 & 43.2 & 14 & DRI & 2,500 \\
\hline 118 & $01-25-89$ & -9.50 & 51.2 & 15 & USGS & 1,800 \\
\hline 121 & $08-10-78$ & -9.41 & 52.7 & 26 & USGS & 1,500 \\
\hline 122 & $01-25-89$ & -9.60 & 52.2 & 15 & USGS & - \\
\hline 127 & $10-06-78$ & -9.96 & 39.9 & 8.4 & USGS & 4,200 \\
\hline 130 & $02-22-78$ & -8.85 & 51.4 & 22 & USGS & 1,100 \\
\hline 131 & $01-26-89$ & -9.20 & 45.1 & 14 & USGS & 2,200 \\
\hline \multicolumn{7}{|c|}{ Thermal aquifer } \\
\hline 45 & $12-07-82$ & -9.20 & 3.4 & -- & -- & -- \\
\hline
\end{tabular}


Water from most wells in the basalt aquifer has tritium concentrations less than $16 \mathrm{pCi} / \mathrm{L}$, indicating that the water is at least 20 years old or is a mixture of pre- and post-nuclear detonation water. Glancy (1986) reported tritium concentrations of $0.6 \mathrm{pCi} / \mathrm{L}$ for water in the basalt aquifer about $6 \mathrm{mi}$ northeast of Fallon (site 52) and less than $0.6 \mathrm{pCi} / \mathrm{L}$ for water from a nearby well. Water in these wells was recharged at least 57 years ago. Water in the Kennametal well (site 87) in the basalt aquifer about 2 mi north of Fallon had a tritium concentration of $2.6 \mathrm{pCi} / \mathrm{L}$ in 1978 and had an age of at least 38 years. The greatest tritium concentrations in water from the basalt aquifer are from wells near the center of Fallon (site 121) and at the Naval Air Station. This high concentration indicates that recharge to the basalt aquifer may be taking place near the center of Fallon and the Rattlesnake Hill area of the Carson Desert. More likely, surface water from irrigation canals is the source of recharge in this area. Recharge may be increasing by pumping of the network of wells completed in the basalt aquifer in the immediate area.

\section{Carbon-14}

Under some conditions, ground-water ages ranging from several hundred to about 30,000 years can be determined using carbon isotopes $\left({ }^{13} \mathrm{C}\right.$ and radioactive $\left.{ }^{14} \mathrm{C}\right)$. Dating of ground water using ${ }^{14} \mathrm{C}$ is complicated because ${ }^{14} \mathrm{C}$ activity can be decreased by the dissolution of minerals and sedimentary organic matter containing ${ }^{14} \mathrm{C}$-depleted carbon in the aquifer, as well as by radioactive decay. Calculation of groundwater ages from ${ }^{14} \mathrm{C}$ concentrations requires detailed information about the carbon sources and reaction paths followed during the geochemical evolution of the water. Alternatively, a model based on assumptions of carbon sources and sinks and their isotopic composition can be used to estimate ages.

Mass-balance calculations (discussed in the section titled "Processes affecting concentrations of major constituents") were used to provide estimates of the carbon sources between waters along reaction paths. Sources of carbon in the intermediate and basalt aquifers could include calcite, organic matter, and atmospheric and soil-zone $\mathrm{CO}_{2}$ gas. The following assumptions were made for ${ }^{13} \mathrm{C}$ values used to determine the amount of carbon moving into the water:
(1) Carbon is added to the water by dissolution of calcite. This calcite is secondary and is assumed to have a delta carbon- $13\left(\delta^{13} \mathrm{C}\right)$ of about -6 to 0 permil. Shell fragments from Pleistocene Lake Lahontan invertebrates are present in the sediment and, if dissolved, would contribute carbon-13 of an unknown composition. No analyses have been made for these specific carbonate sources to substantiate these assumptions. Ten core samples were analyzed for the carbon-isotope composition of inorganic carbon and have values ranging from -6.8 to -0.8 permil and the median $\delta^{13} \mathrm{C}$ value is -1.3 permil. Because the above values represent a combination of carbon sources, the composition of individual sources is not known.

(2) Carbon supplied to water, other than carbon from calcite dissolution, is assumed to be the result of dissolution of soil-zone $\mathrm{CO}_{2}$ gas. Oxidation of sedimentary organic matter is considered to be minor, especially in the basalt aquifer. Sediment comprising the intermediate aquifers has been saturated for at least $3,000-5,000$ years. During that time, most of the sedimentary organic carbon probably has been oxidized. Modeling results-presented in the section of this report titled "Processes affecting concentrations of major constituents"-also indicate that sedimentary organic carbon is not an important source for dissolved carbon in the intermediate aquifers. The basalt aquifer, because of its igneous origin, is assumed to have no sedimentary organic carbon.

(3) The initial recharge water is assumed to have a ${ }^{13} \mathrm{C}$ composition of -4 to -11 permil. Two analyses of surface water used for irrigation have been reported for the Carson Desert; a sample collected from an irrigation canal reported by Lico and others (1987) has a $\delta^{13} \mathrm{C}$ of -4.3 permil, and a sample collected from the Truckee Canal (supplies water from the Truckee River to Lahontan Reservoir) has a $\delta^{13} \mathrm{C}$ of -9.6 permil (Rowe and others, 1991). Water samples collected by the U.S. Geological Survey during 1990-91 on the Walker and Truckee Rivers have average ${ }^{13} \mathrm{C}$ values of -10.5 and -10.1 permil, respectively (L.V. Benson, U.S. Geological Survey, written commun., 1991). The range of values for the Walker River is -11.7 to -9.3 permil for 15 samples. The range of values for the Truckee River is -11.1 to -9.6 permil for 9 samples. Because the Walker and Truckee River Basins bound the Carson River Basin and the carbon-isotope composition is similar in both rivers, the carbon-isotope composition of the Carson River is assumed to be near the values for these two rivers. 
(4) The recharge water is assumed to have a ${ }^{14} \mathrm{C}$ activity of 100 percent modern carbon (PMC). There are no measurements of the Carson River to substantiate this, but it is possible to assume that the river water is in equilibrium with atmospheric carbon dioxide $\left(\mathrm{CO}_{2}\right)$. The initial ${ }^{14} \mathrm{C}$ activity depends on the source of carbon in the river. The activity would be about $50 \mathrm{PMC}$ if it resulted from mixing equal amounts of carbon from modern $\mathrm{CO}_{2}(100 \mathrm{PMC})$ and ${ }^{14} \mathrm{C}$-depleted carbonate minerals ( 0 PMC). If the carbonate minerals dissolved to produce the carbon in the river are secondary (0-100 PMC), then the ${ }^{14} \mathrm{C}$ activity of the river water would be between 50 and 100 PMC. Similarly, the initial ${ }^{14} \mathrm{C}$ activity would be near $100 \mathrm{PMC}$ if the carbon is mostly the result of weathering of noncarbonate rocks by carbonic acid.

The different models used to calculate ${ }^{14} \mathrm{C}$ ages are described by Plummer and others (1991). Groundwater ages listed in table 1 were calculated by NETPATH (a computer program) using the "original data" model (Plummer and others, 1991). The time since recharge (isolation from the atmosphere) of the water was calculated by correcting the ${ }^{14} \mathrm{C}$ composition of the recharge water for the inferred chemical evolution during travel and then comparing that corrected ${ }^{14} \mathrm{C}$ age to the measured ${ }^{14} \mathrm{C}$ of the ground water. The time since recharge is calculated by using the equation:

$$
t=8,267 \times\left[\ln \left(\frac{{ }^{14} \mathrm{C}(\text { corrected })}{{ }^{14} \mathrm{C}(\text { measured })}\right)\right],
$$

where

$$
\begin{aligned}
& t \text { is the corrected }{ }^{14} \mathrm{C} \text { age of the } \\
& \text { water, in years; } 8,267 \text { is the half } \\
& \text { life of }{ }^{14} \mathrm{C} \text { divided by the natural } \\
& \log \text { of } 2 \text {, in years; }
\end{aligned}
$$

The ${ }^{14} \mathrm{C}$ ages for water in the intermediate aquifers range between modern and 7,700 years. The oldest is from the northernmost and southernmost wells towards the ends of the flow paths. The youngest water is from wells near major canals near the center of Fallon and the wells nearest Lahontan Reservoir.
As mentioned above, the basalt aquifer near the center of Fallon, is being recharged by some modern water and one may conclude that the intermediate aquifers also are being recharged in that area and near Lahontan Reservoir.

Because the amount of recharge the basalt aquifer receives is not known, no corrections were made for contributions of modern water. Thus the ages given in table 1 probably are minimum ages.

The presence of measurable amounts of tritium in water from the basalt aquifers suggest the ${ }^{14} \mathrm{C}$ ages have been underestimated. Recharge of as little as 20 percent modern water could account for the measured tritium concentrations and reduce the apparent ${ }^{14} \mathrm{C}$ age of the water by several thousand years. This suggests that prehistoric Lake Lahontan may be the source of water in the basalt aquifer. The ${ }^{14} \mathrm{C}$ ages in table 2 indicate that the age of water in the basalt aquifer ranges from 1,100 to 8,100 years. The oldest water is at site 52, the northernmost well. This agrees with the conclusion presented above that the northeast part of the basalt aquifer is the distal end of the flow system.

\section{WATER QUALITY AND AQUEOUS GEOCHEMISTRY}

This section provides a description of the chemical composition of ground water in the Carson Desert and the processes that control concentrations of solute in the different aquifers. The processes that affect the composition of water in the thermal aquifers will not be discussed in this report (see Olmsted and others, 1984) and the processes responsible for the water quality observed in the shallow aquifer can be found in reports from other studies (Lico and others, 1987; Lico, 1992; A.H. Welch, U.S. Geological Survey, written commun., 1991).

Ground water is the major source of drinking water in Nevada for both private-domestic and publicsupply sources. The Nevada State drinking-water standards are used in this report as a reference for the acceptability of a water source for human consumption. These standards (table 2), which apply only to publicsupply systems, consist of maximum contaminant levels (MCL's), secondary maximum contaminant levels (SMCL's), and secondary preferred standards (SPS's). The MCL's are health related and Federally enforceable and specify the maximum concentrations allowed to be delivered to the user of a public water- 
supply system. The MCL's were adopted from the U.S. Environmental Protection Agency's National Drinking Water Regulations (1986 a, b, and c) with the addition of a 2 milligram per liter $(\mathrm{mg} / \mathrm{L})$ standard for fluoride. MCL's have been proposed by the U.S. Environmental Protection Agency (1991) for radon-222, uranium, radium-226, and radium-228 (300 pCi $/ \mathrm{L}, 20 \mu \mathrm{g} / \mathrm{L}, 20 \mathrm{pCi} / \mathrm{L}$, and $20 \mathrm{pCi} / \mathrm{L}$, respectively). It should be noted that the uranium MCL is expressed in mass terms whereas the other radionuclides are expressed in units of radioactivity. The aesthetic quality of water is mandated by State standards (SMCL's) that are not Federally enforceable. SPS's apply to public water purveyors, unless water of that quality is not available, in which case, the MCL's and SMCL's apply (Nevada Bureau of Consumer Health Protection Services, 1980, p. 8).

\section{Surface Water}

To understand how water quality changes as the water moves through an aquifer system, it is important to know the chemical characteristics of dissolved constituents in the recharge water. The Carson and
Truckee Rivers are the major source of most recharge in the Carson Desert. Statistical information for chemical quality of Carson River water below Lahontan Reservoir is shown in figure 11. Flow along this reach of the Carson River includes water diverted from the Truckee River into the Carson River Basin through the Truckee Canal. The relative abundances of major ions, $\mathrm{pH}$, and dissolved-solids concentrations are shown in figure 12.

Boxplots and modified trilinear diagrams are used to display the large number of data points in this report. Boxplots display summary statistics for the distribution of reported concentrations for selected constituents. The statistical components are represented visually by features known as "boxes" and "whiskers," and are described as follows: The box defines the spread of the middle 50 percent of the data (that is, the concentrations that lie between the 25 th and 75 th percentiles). The median value of the data (50th percentile) is indicated by the horizontal line within the box. The vertical lines beyond each end of the box are called whiskers. They show the range of concentrations and extend beyond the ends of the box to the maximum and minimum data values.

Table 2. Nevada State drinking-water standards for public water systems

[Units of measure: milligrams per liter, except as noted. --, standard does not exist for the indicated constituent or property]

\begin{tabular}{|c|c|c|c|c|}
\hline & Constituent or property & $\begin{array}{l}\text { Maximum } \\
\text { contaminant } \\
\text { level (MCL) }{ }^{1}\end{array}$ & $\begin{array}{c}\text { Secondary } \\
\text { maximum } \\
\text { contaminant } \\
\text { level (SMCL) }\end{array}$ & $\begin{array}{c}\text { Secondary } \\
\text { preferred } \\
\text { standard } \\
\text { (SPS) }\end{array}$ \\
\hline \multicolumn{5}{|c|}{ Inorganic constituents and properties } \\
\hline Arsenic & & 0.05 & -- & -- \\
\hline Barium & & 1.0 & -- & -- \\
\hline Cadmium & & .01 & -- & -- \\
\hline Chloride & & -- & 400 & 250 \\
\hline Chromium & & .05 & -- & -- \\
\hline Copper & & -- & -- & 1.0 \\
\hline Fluoride & & 4.0 & 2.0 & -- \\
\hline Iron & & - & .6 & .3 \\
\hline Lead & & .05 & - & -- \\
\hline Magnesium & & -- & 150 & 125 \\
\hline
\end{tabular}


Tabie 2. Nevada State drinking-water standards for public water systems-Continued

\begin{tabular}{|c|c|c|c|}
\hline Constituent or property & $\begin{array}{l}\text { Maximum } \\
\text { contaminant } \\
\text { level (MCL) }^{1}\end{array}$ & $\begin{array}{c}\text { Secondary } \\
\text { maximum } \\
\text { contaminant } \\
\text { levei (SMCL) }\end{array}$ & $\begin{array}{c}\text { Secondary } \\
\text { preferred } \\
\text { standard } \\
\text { (SPS) }^{3}\end{array}$ \\
\hline \multicolumn{4}{|c|}{ Inorganic constituents and properties-Continued } \\
\hline Manganese & -- & .1 & .05 \\
\hline Mercury & .002 & -- & -- \\
\hline Nitrate (as N) & 10 & -- & -- \\
\hline Selenium & .01 & -- & -- \\
\hline Silver & .05 & -- & -- \\
\hline Sulfate & -- & 500 & 250 \\
\hline Total dissolved solids & -- & 1,000 & 500 \\
\hline Zinc & -- & -- & 5.0 \\
\hline $\mathrm{pH}$ & -- & -- & $6.5-8.5$ \\
\hline \multicolumn{4}{|c|}{ Organic compounds } \\
\hline Benzene & 0.005 & -- & -- \\
\hline Carbon tetrachloride & .005 & -- & -- \\
\hline Endrin & .0002 & -- & -- \\
\hline Lindane & .004 & -- & -- \\
\hline Methoxychlor & .1 & -- & -- \\
\hline Trichloroethylene & .005 & -- & -- \\
\hline Toxaphene & .005 & -- & -. \\
\hline Trihalomethanes, total & .1 & -- & -- \\
\hline Vinylchloride & .002 & -- & -. \\
\hline 1,2-Dichloroethane & .005 & -- & -- \\
\hline 1,1-Dichloroethylene & .007 & -- & -- \\
\hline 1,4-Dichlorobenzene & .075 & -- & -- \\
\hline 1,1,1-Trichloroethane & .2 & -- & -- \\
\hline 2,4-Dichlorophenoxyacetic acid (2,4-D) & .1 & .- & .07 \\
\hline $2,4,5$-Trichlorophenoxypropionic acid $(2,4,5-\mathrm{T})$ & .01 & -- & .07 \\
\hline \multicolumn{4}{|c|}{ Radionuclides } \\
\hline $\begin{array}{l}\text { Adjusted gross alpha }{ }^{4} \text { (excluding } \\
\text { radium-226, radon, and uranium), in picocuries per liter }\end{array}$ & 15 & -- & -- \\
\hline Gross beta, in millirems per year & 4 & -- & - \\
\hline Radium-226 and -228 (combined), in picocuries per liter & 5 & -- & -- \\
\hline Radium-226 $6^{4}$ in picocuries per liter & 20 & -- & -- \\
\hline Radium- $228^{4}$, in picocuries per liter & 20 & -- & -- \\
\hline Radon- $222^{4}$, in picocuries per liter & 300 & -- & -- \\
\hline Uranium $^{4}$ & .02 & -- & -- \\
\hline
\end{tabular}

${ }^{1}$ Maximum contaminant levels (MCL's) are health related and State and Federally mandated. Best available technology as determined by the U.S. Environmental Protection Agency must be utilized to achieve these levels (Jeffrey A. Fontaine, Nevada Bureau of Consumer Health Protection Services, oral commun., 1989). MCL's are adopted by the State of Nevada (Nevada Bureau of Consumer Health Protection Services, 1980) from the National Drinking Water Regulations (U.S. Environmental Protection Agency, 1986a, 1986b).

${ }^{2}$ Secondary maximum contaminant levels (SMCL's) are based on aesthetic qualities and are enforceable by the State of Nevada (State of Nevada, 1980). Best available technology is determined by the State of Nevada (Jeffrey A. Fontaine, Nevada Bureau of Consumer Health Protection Services, oral commun., 1989). SMCL's, except that for magnesium, are adopted from National Drinking Water Regulations (U.S. Environmental Protection Agency, 1986c, p. 587-590). SMCL's have not been established by the State of Nevada for copper, $\mathrm{pH}$, and zinc.

${ }^{3}$ Secondary preferred standards (SPS's) must be met unless water of that quality is not available, in which case the SMCL's must be met if they exist (Nevada Bureau of Consumer Health Protection Services, 1980, p. 8-9).

${ }^{4}$ Standard has been proposed, but not promulgated as of 1991 (U.S. Environmental Protection Agency, 1991). 


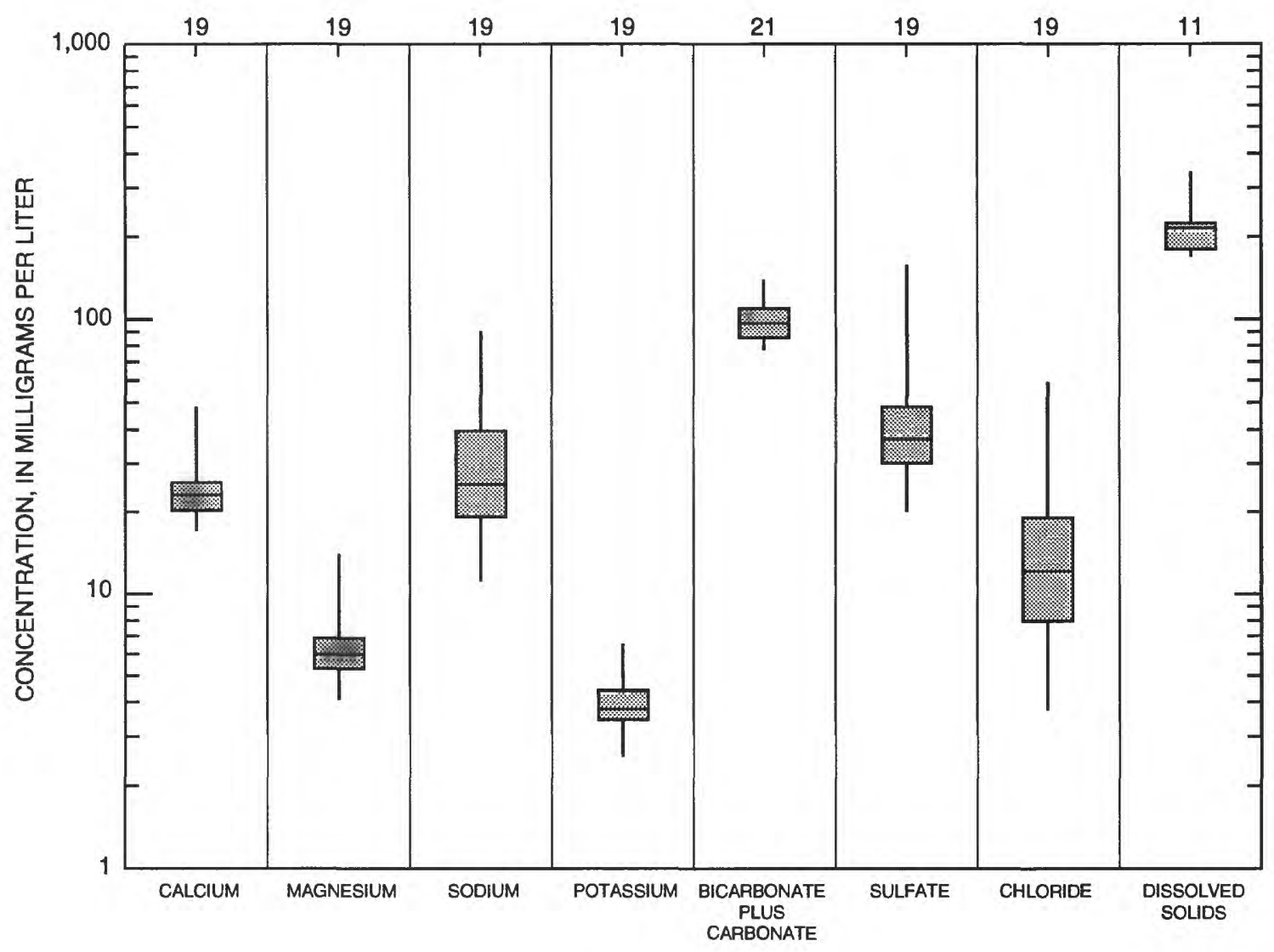

EXPLANATION

21 NUMBER OF ANALYSES

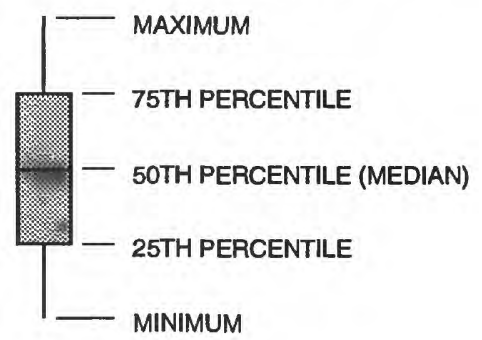

Figure 11. Concentration of major constituents and dissolved solids in the Carson River downstream of Lahontan Reservoir (U.S. Geological Survey gage 10312150) for the period water years 1978-79.

Modified trilinear diagrams display the general ionic composition, $\mathrm{pH}$, and dissolved-solids concentrations of water samples. The diagram consists of five fields - two triangular and three rectangular (Zaporozec, 1972, p. 38). Each chemical analysis is plotted as five points on the diagram. In combination, the five points for each sample provide a general indication of the overall chemical composition of the water. The relative proportions of major cations (calcium, magnesium, and sodium plus potassium) and major anions (sulfate, chloride, and carbonate plus bicarbonate) are shown on the left and upper triangles, respectively. The $\mathrm{pH}$ and dissolved-solids concentrations for the water samples are plotted in the bottom and right rectangles, respectively. This type of diagram provides a visual characterization, on a single illustration, of eight major chemical constituents, $\mathrm{pH}$, and dissolved-solids content of the ground water in a particular area. The diagram shows how the data group in the five triangular or rectangular areas. The central 


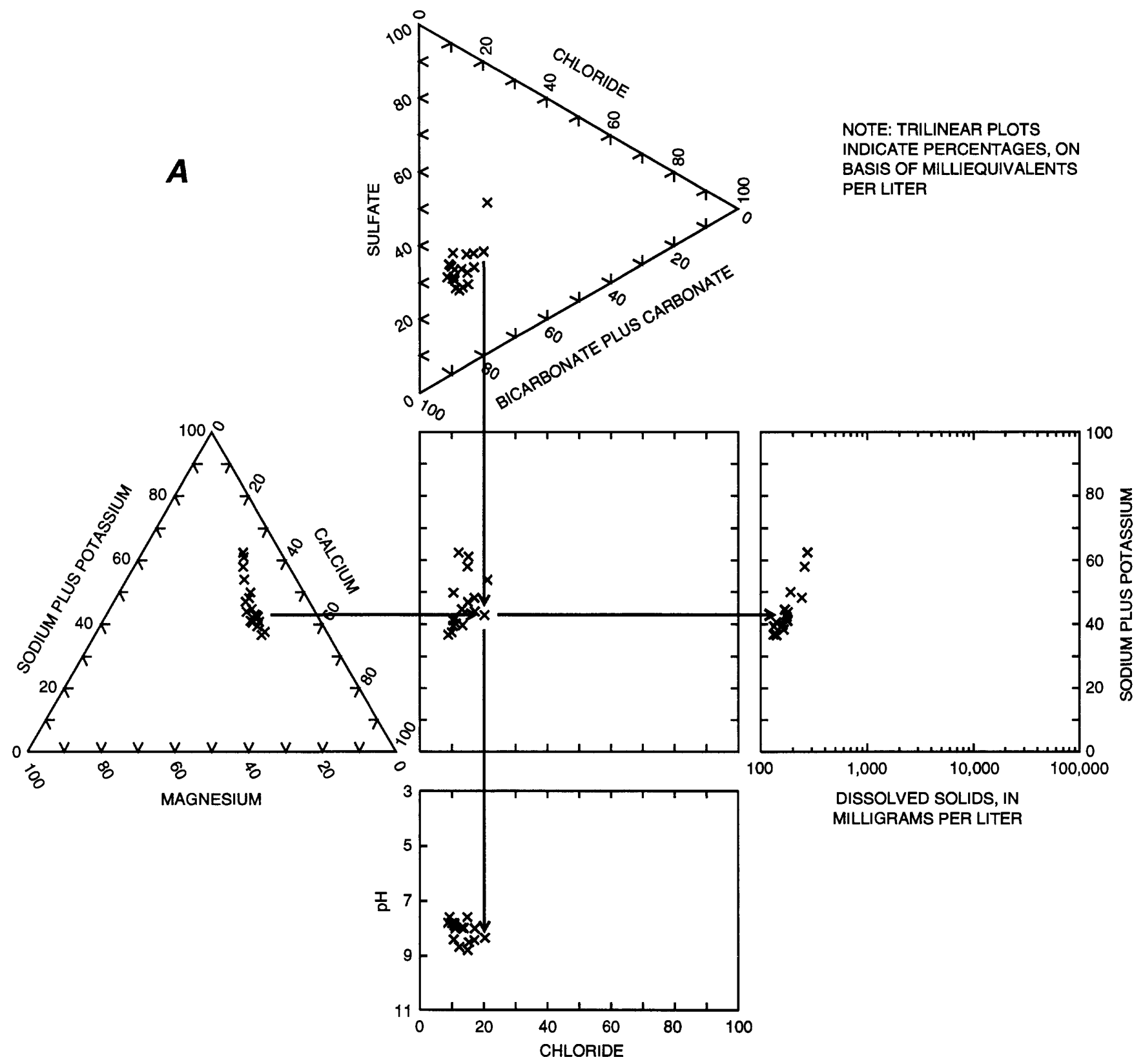

Figure 12. General chemical composition of water. $A$, Carson River; $B$, ground water. Arrows in $A$ show how data in separate fields correlate.

rectangle is a transitional area to connect the four outside triangular and rectangular plots. On some plots, the data are crowded, which makes distinguishing individual symbols impossible. Where crowding presents this problem, an alternative approach is to display fields that enclose either 50 or 75 percent of the data in each of the five areas. The fields are defined using polar smoothing routines developed by Helsel (Dennis Helsel, U.S. Geological Survey, written commun., 1991).
Nineteen water analyses are available for the Carson River below the Lahontan Reservoir gage for the years 1978-89 and include discharge values that range from 1.3 to $1,420 \mathrm{ft}^{3} / \mathrm{sec}$. The predominant constituents are sodium, calcium, and bicarbonate. The dissolved-solids concentration ranges from 172 to $317 \mathrm{mg} / \mathrm{L}$, with a median of $216 \mathrm{mg} / \mathrm{L}$. The $\mathrm{pH}$ ranges from 7.4 to 8.9 , with a median $\mathrm{pH}$ of 8.0. A representative chemical analysis of Carson River water is listed in table 3. 


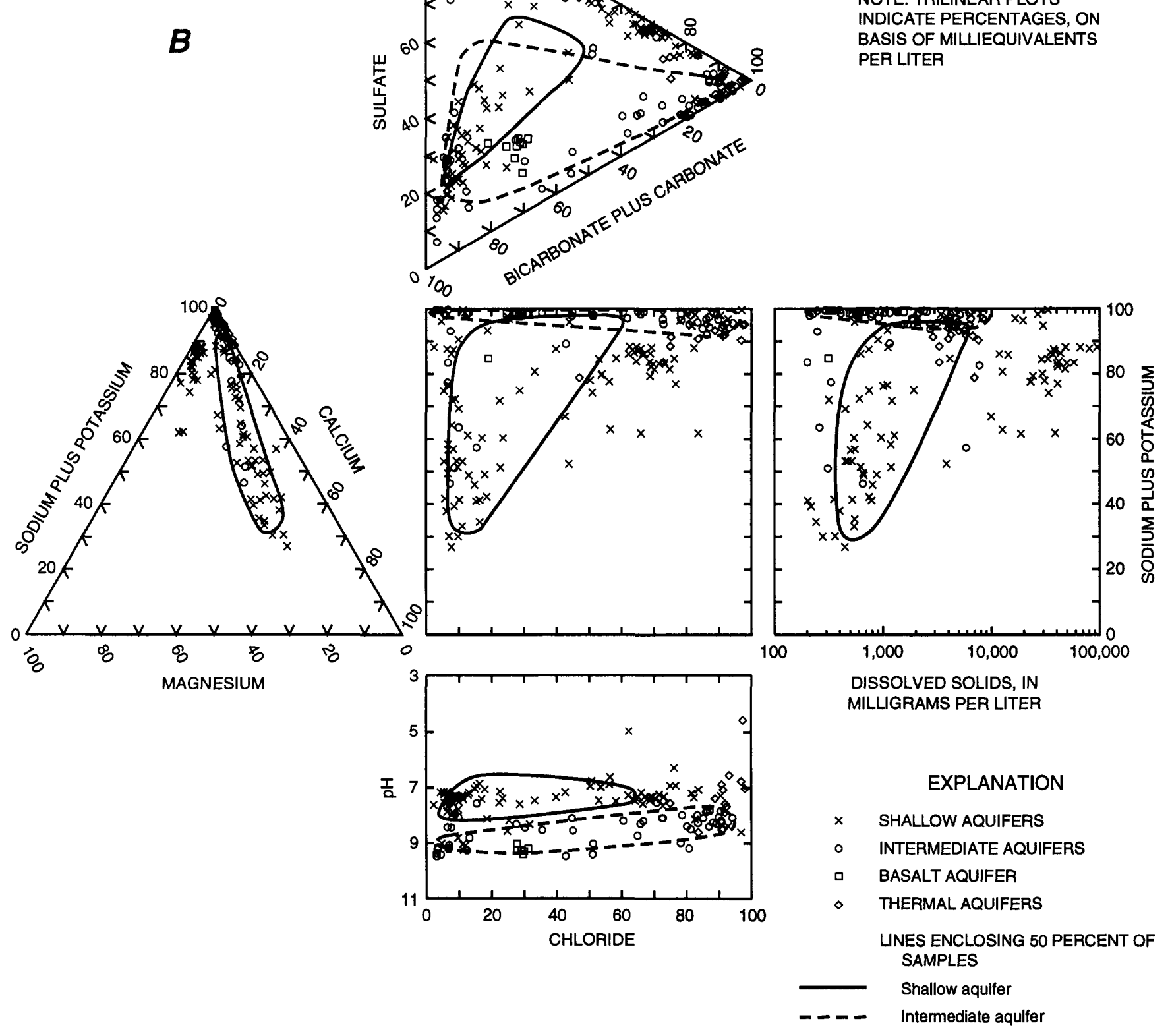

Figure 12.-Continued.

Other water-quality oriented studies in the Carson Desert (Hoffman and others, 1990; Rowe and others, 1991; Lico, 1992) have described different aspects of surface-water quality, mostly in the discharge areas of Stillwater Wildlife Management area and Carson Lake (Carson Pasture). These reports include a few analyses from the Carson River downstream of Lahontan Reservoir. The chemical composi- tion of water from agricultural return flow has been described by Hoffman and others, 1990; Rowe and others, 1991; and Lico, 1992). This water is transported in drains and can be a source of recharge in the distal parts of the ground-water flow systems in the southern Carson Desert. In the Fallon area, the drains are removing water from the shallow aquifers thus lowering the water table. 


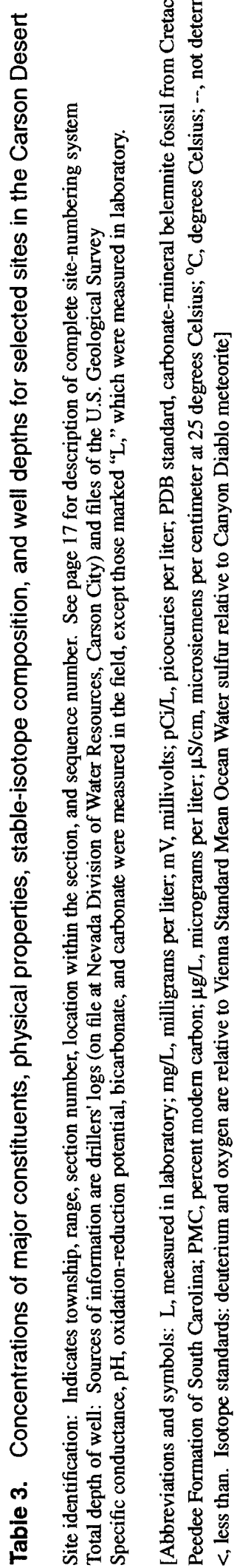

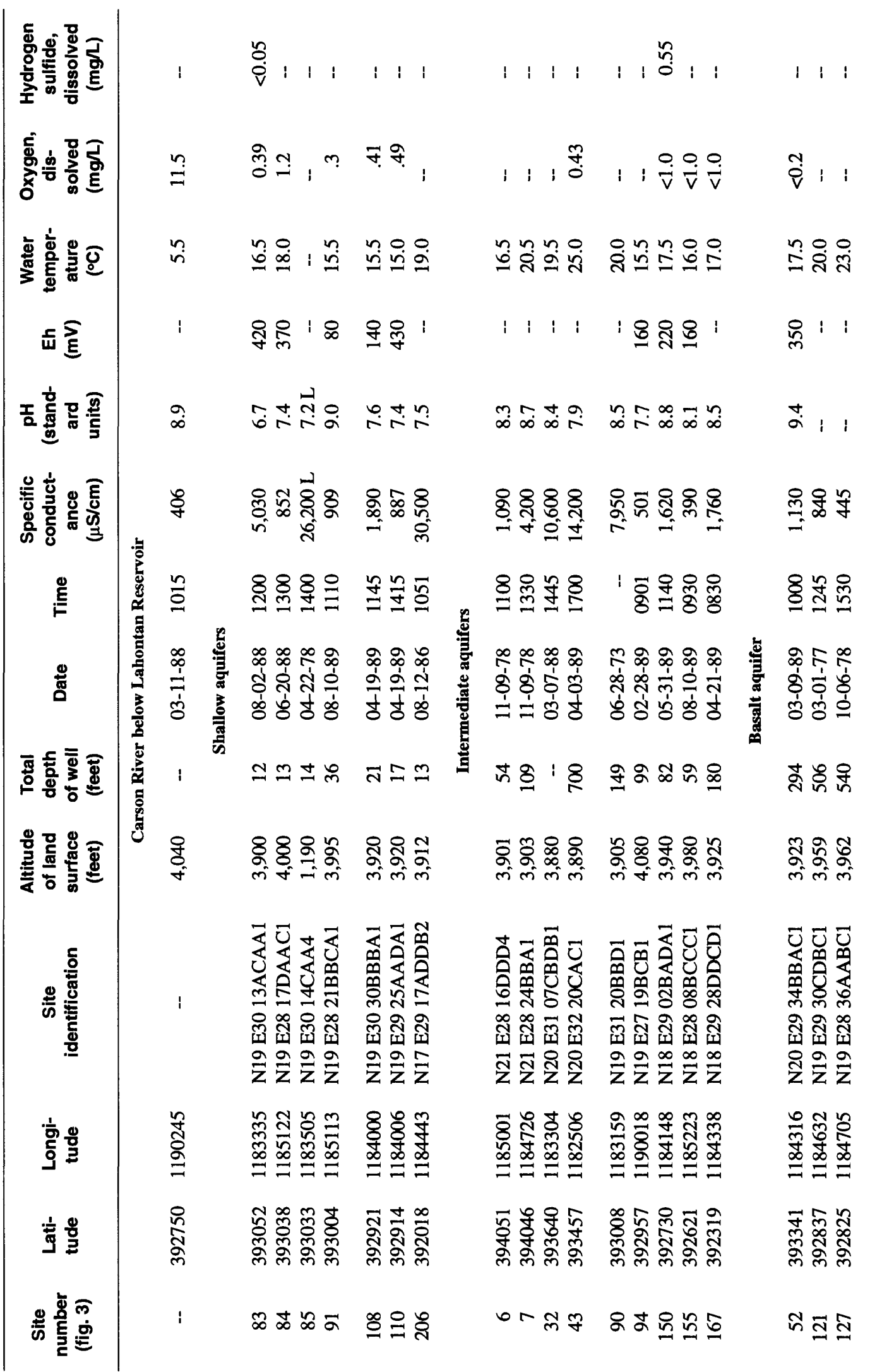




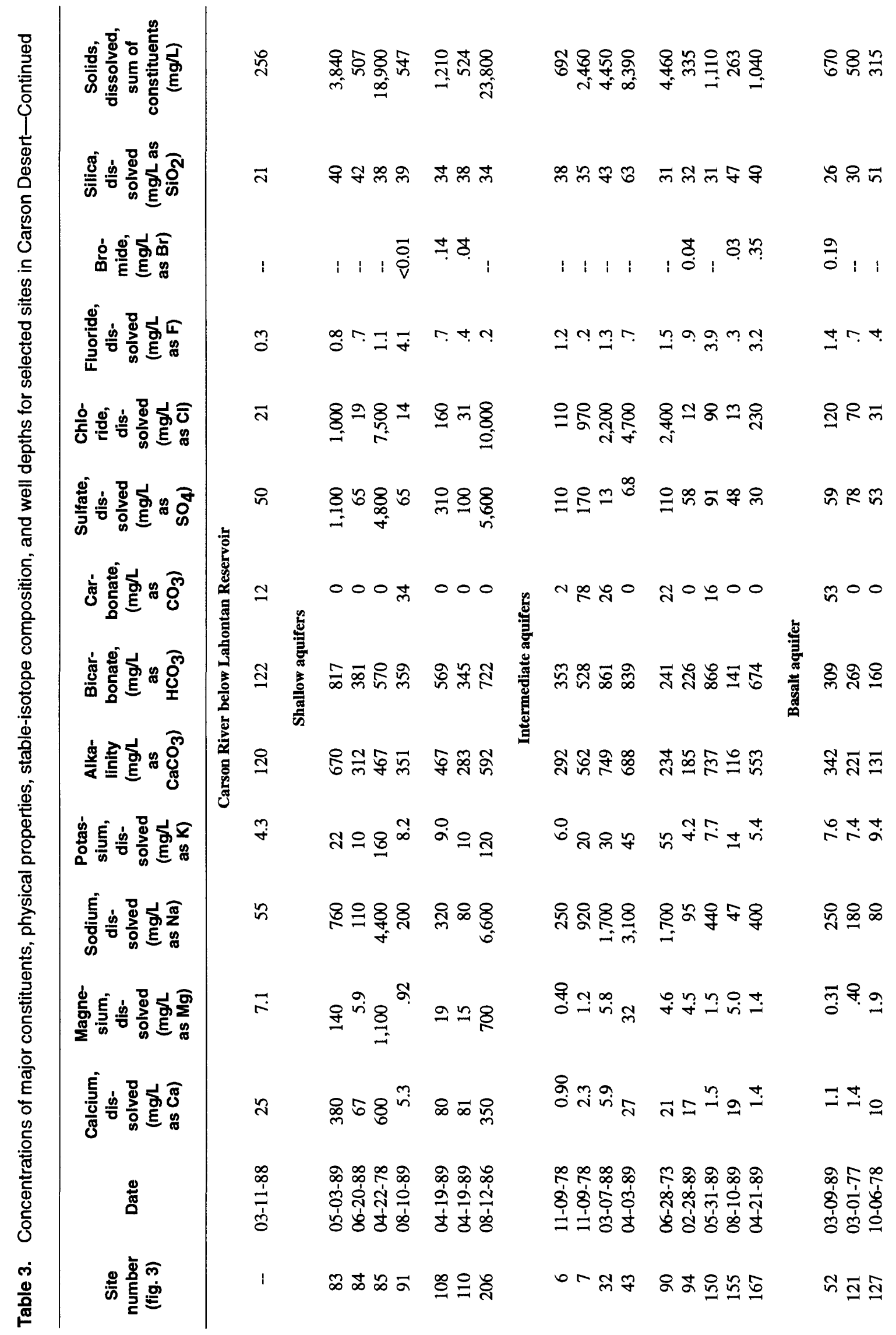




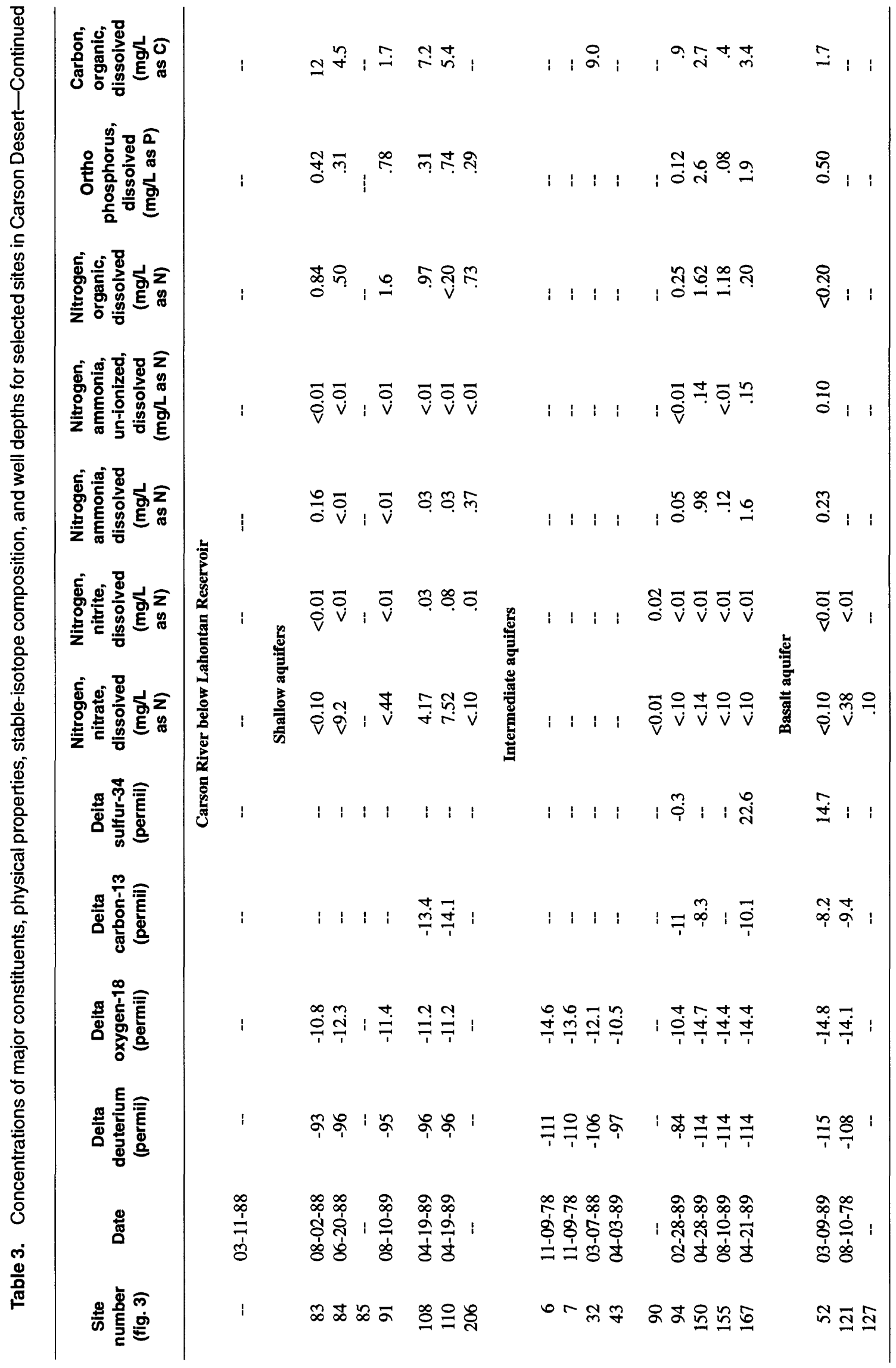




\section{Ground Water}

Most of the data used to describe the quality of ground water in the Carson Desert were collected as part of the NAWQA program (Whitney, 1994). Several other sources of water-quality data also were used to aid in this description, these include: Morgan (1982), Olmsted and others (1984), Olmsted (1985), Glancy (1986), Lico and others (1987), Hoffman and others (1990), Rowe and others (1991), and Lico (1992).

Characterization of the water quality in the Carson Desert is only as good as the data set used in that characterization. In that regard, the available data for the quality of water in the ground-water system in the Carson Desert have some limitations. The number of samples from the shallow aquifers far exceeds those from the other aquifers (intermediate and basalt aquifers). The basalt aquifer, in particular, has only a few tens of wells completed in it, thus it may be underrepresented in the data set. Also, many of the wells in the shallow aquifers are observation wells and are not used for public supply, whereas the wells in the intermediate and basalt aquifers are almost exclusively used for public supply. This fact may not allow for a direct comparison of water quality between the shallow aquifers and the intermediate and basalt aquifers. Another bias may be that wells with unacceptable water quality, especially in the intermediate and basalt aquifers, probably would be abandoned, leaving only the wells with acceptable water quality for sampling. The methods of well completion for wells in the shallow aquifers commonly are different from those used for intermediate and basalt wells. Typically, the public supply wells of the intermediate and basalt aquifers are perforated over large or multiple vertical intervals, whereas the wells in the shallow aquifers are open to relatively short intervals. Also, the open intervals of wells usually are placed in the more productive sands (coarser grained) and may bias samples by not including water from the fine-grained sediment within the aquifer

The following part of the report contains four sections that discuss the major inorganic constituents, minor inorganic constituents, radionuclides, and synthetic organic compounds in ground water of the Carson Desert. For the purposes of this report, major constituents are those that make up most (greater than 98 percent) of the solute content; minor constituents are generally present at concentrations of less than $1 \mathrm{mg} / \mathrm{L}$.
Each subsection describes the general water quality and the relation to Nevada State drinking-water standards and the processes that affect the observed quality.

\section{Major Inorganic Constituents}

\section{Water Quality and its Relation to Nevada State Drinking-Water Standards}

Plots showing the chemical composition of water from the entire ground-water system in the Carson Desert are in figure 12. Ground water varies from a dilute calcium bicarbonate water, similar to that of the Carson River, to a saline sodium chloride type. Typically, as the dissolved solids increase, sodium and chloride become the dominant ions in solution. The more saline water (greater than $10,000 \mathrm{mg} / \mathrm{L}$, dissolved solids) is found in the shallow aquifer in areas that are not irrigated, such as Stillwater Wildlife Management Area, Carson Lake (Carson Pasture), and Soda LakesUpsal Hogback area. These areas are discharging ground water and are highly affected by evaporation, as previously discussed in the section "Movement of ground water and isotope hydrology."

The statistical distribution of major constituents in ground water from the shallow aquifers is shown in figure 13. In general, water in the shallow aquifers is similar to that of the Carson River below Lahontan Reservoir and is dominated by sodium, calcium, sulfate, and bicarbonate. The dissolved-solids concentrations range from 205 to $93,800 \mathrm{mg} / \mathrm{L}$ and have a median of $1,990 \mathrm{mg} / \mathrm{L}$. The $\mathrm{pH}$ generally ranges from 6 to 9 and has a median $\mathrm{pH}$ of 7.4. Representative analyses of ground water in the Carson River Basin are listed in table 3.

In general, concentrations of dissolved solids in the shallow aquifers are lowest in the vicinity of Fallon and are greatest in the surrounding areas near Stillwater Marsh, Carson Lake, and the Soda LakesUpsal Hogback area (fig. 14). Concentrations of dissolved solids are greatly affected by local conditions such as proximity to canals, drains, and irrigated fields, and evaporation. Wells at sites 108 and 110 (fig. 3) are only a few hundred feet apart, but the dissolved-solids concentration at site $110(524 \mathrm{mg} / \mathrm{L})$ is less than onehalf of that at site $108(1,210 \mathrm{mg} / \mathrm{L})$. Glancy (1986) and Lico and others (1987) also described the highly variable ground water in the shallow aquifers. Site 110 is near an unlined irrigation canal and ground water probably is affected by seepage from that canal. 


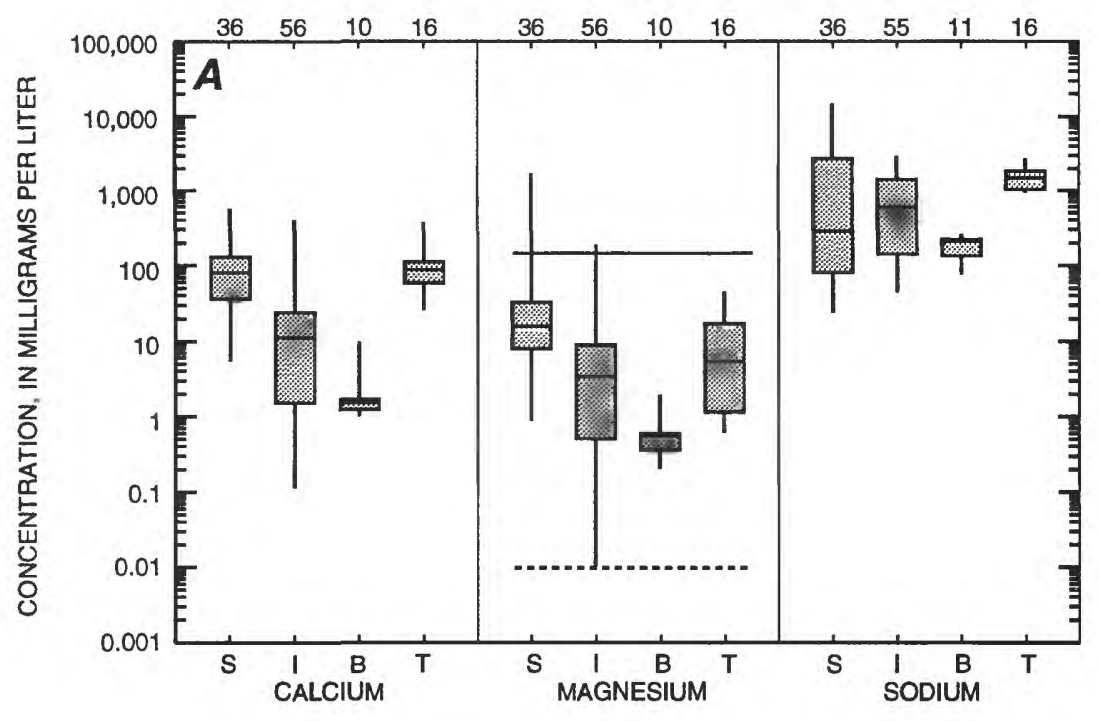

EXPLANATION

11 NUMBER OF ANALYSES
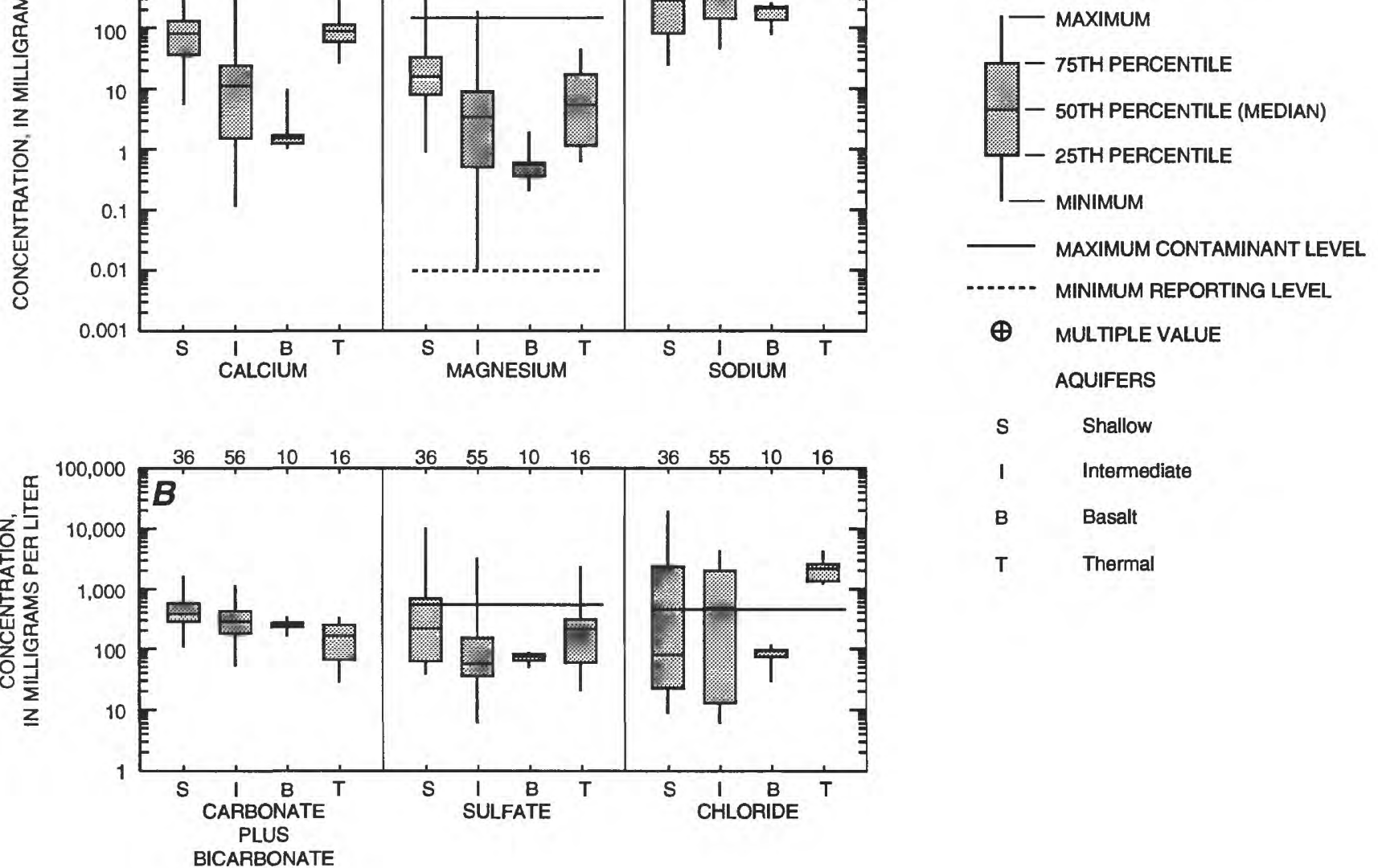

AQUIFERS

S Shallow

I Intermediate

B Basalt

T Thermal
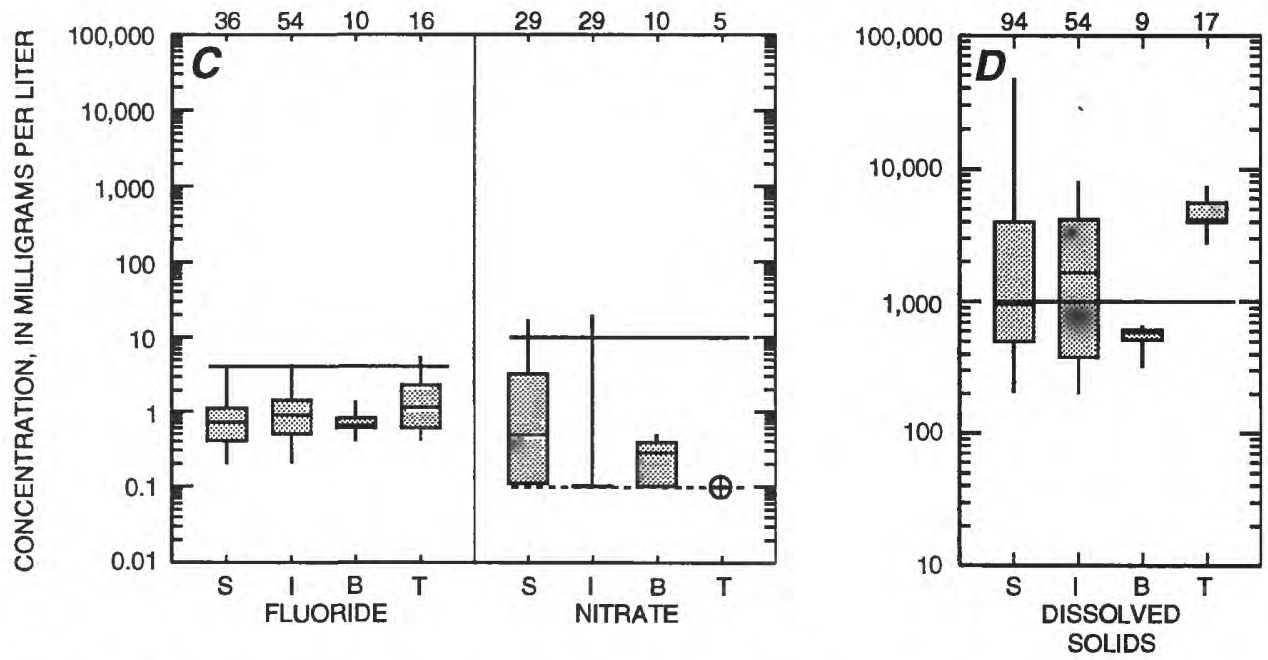

Figure 13. Concentrations of major constituents and dissolved solids in ground water in the Carson Desert. A, calcium, magnesium, and sodium; $B$, inorganic carbon, sulfate, and chloride; $C$, fluoride and nitrate; and $D$, dissolved solids. 


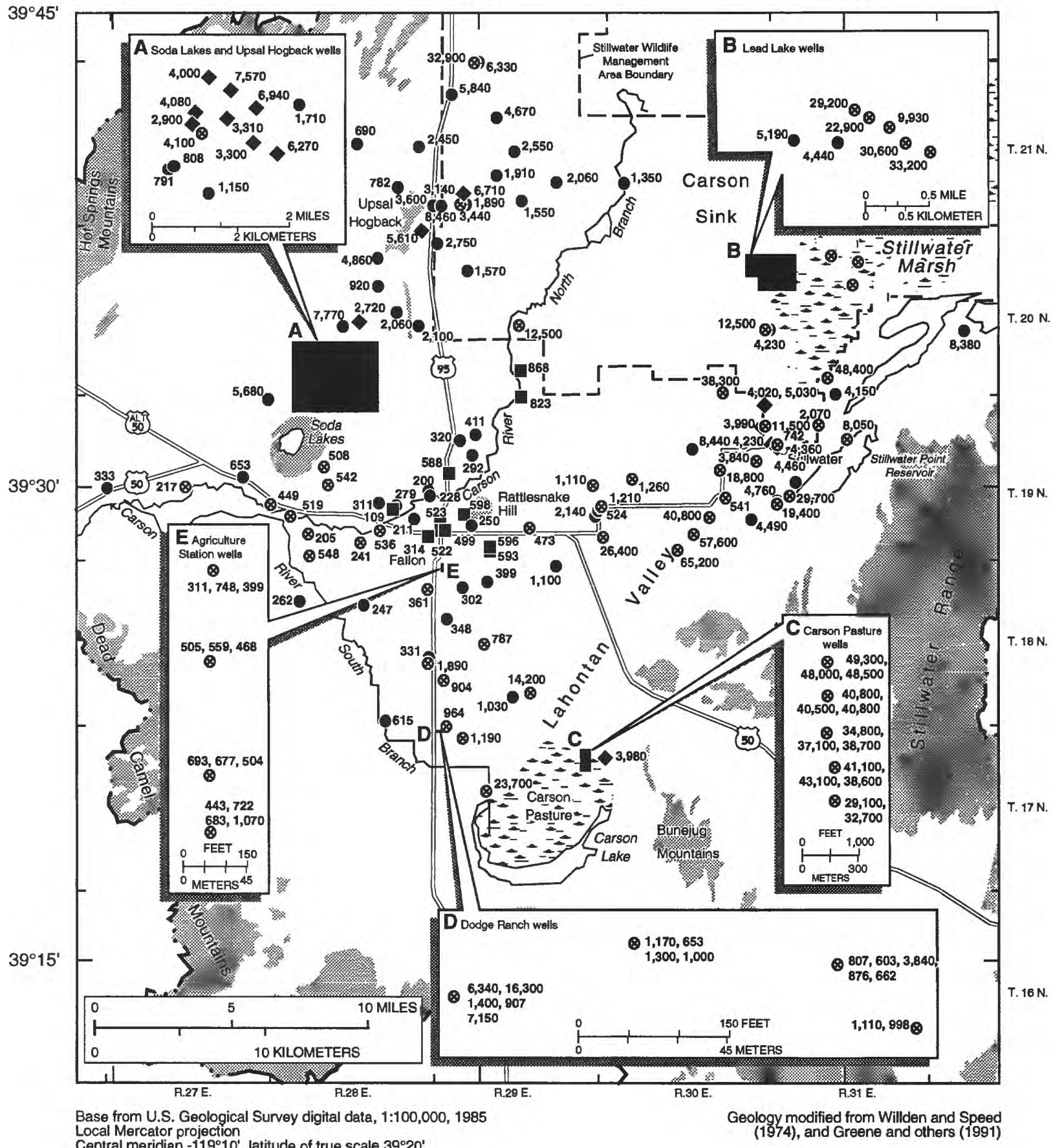

Central meridian $-119^{\circ} 10^{\circ}$, latitude of true scale $39^{\circ} 20^{\prime}$

\section{EXPLANATION}

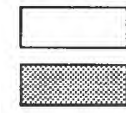

BASIN-FILL DEPOSITS

CONSOLIDATED ROCKS

HYDROGRAPHIC AREA BOUNDARY

1974), ar

SAMPLING SITE - Number is dissolvedsolids concentration, in milligrams per liter

Q 606 Shallow aquifer

2,550 Intermediate aquifer

口596 Basait aquifer

3,980 Thermal aquifer

Figure 14. Dissolved-solids concentrations in ground water. 
Ground water in the shallow aquifers has a highly variable chemistry. One possible explanation for the variable composition of ground water in these aquifers may be their complex hydrologic framework. Flow of water in the aquifers is determined by a very sitespecific combination of location of unlined canals and ditches, amount and timing of irrigation, type of crops grown or other nonirrigated plant types, depths to water table, and the physical characteristics of sediments. The location of unlined canals, which are sources of recharge for the shallow aquifers, and ditches (surface drains that are discharge points for the aquifers in the irrigated areas) commonly determine the direction of ground-water flow in the upper $30 \mathrm{ft}$ or so in areas as small as one-sixteenth of an acre (Lico and others, 1987). The direction of ground-water flow in these small parcels can be totally different from that of the basin-wide flow in the aquifers. Recharge of the shallow aquifers occurs through the application of water, typically by flood irrigation, to the fields in the Fallon area. As previously stated, this and leakage from canals has resulted in a rise in the water table by as much as $60 \mathrm{ft}$, probably much less on the average, since the advent of irrigation in the Carson Desert (early 1900's). Evaporation from open water bodies and evapotranspiration from alfalfa, pasture, bare ground, and native vegetation are major sources of discharge from the aquifers.

The shallow basin-fill aquifers have highly variable hydraulic properties (permeability and storage capacity) both horizontally and vertically. This is a result of deposition by fluvial processes that typically form fine-grained overbank deposits and coarsergrained channel deposits. Fine-grained lake deposits are interbedded with these deposits and tend to be more laterally extensive. The result of this heterogeneous sedimentary section is that ground water does not flow uniformly throughout the Carson Desert. As a result, the quality of ground water in the finer-grained sediment commonly is different from that in the coarsergrained sediment. Some of the hydrologic complexity of the shallow aquifers is depicted in figure 15 .

The composition of water in the intermediate aquifers falls into two types: one a saline, sodium chloride water associated with the Soda Lakes-Upsal Hogback area; the other a dilute sodium bicarbonate water in the central Fallon area. Figure 12 shows the distribution of major ions in water from the intermediate aquifers. In the Fallon area, the dissolved-solids concentrations range from 201 to $2,140 \mathrm{mg} / \mathrm{L}$ and have a median of $335 \mathrm{mg} / \mathrm{L}$. In the Soda Lakes-Upsal Hogback area, the water is distinctly more saline with dissolved-solids concentrations ranging from 690 to $7,770 \mathrm{mg} / \mathrm{L}$ and have a median value of $3,100 \mathrm{mg} / \mathrm{L}$. The $\mathrm{pH}$ ranges from 7.5 to 9.5 and the median $\mathrm{pH}$ is 9.1 in the Fallon Area. In the Soda Lakes-Upsal Hogback area, the $\mathrm{pH}$ ranges from 6.8 to 9.4 with a median $\mathrm{pH}$ of 8.1. Water from the well at site 94 (fig. 3) in the Fallon area is dominantly sodium, calcium, bicarbonate, and sulfate and is similar in composition to water from some of the shallow wells and the Carson River. This well is located close to the Carson River channel and probably is recharged by the river or nearby irrigation canals. The composition of this sample, as an example, illustrates that the composition of recharge water is a major factor in the observed quality of ground water in the intermediate aquifers. The dominant constituents in water from two wells southeast of Fallon (sites 150 and 167, fig. 3) are sodium, bicarbonate, and chloride. In general, the chemical composition is similar to water in the basalt aquifer and indicates that the basalt aquifer may influence the water quality of the surrounding intermediate aquifers.

The distribution of dissolved-solids concentrations in the intermediate and basalt aquifers is shown in figure 14. In the intermediate aquifers, the lowest dissolved-solids concentrations are clustered in the actively irrigated area around Fallon; the higher concentrations are to the north near the Soda Lakes-Upsal Hogback area, to the south near Carson Lake, and to the east near Stillwater Marsh. Dissolved-solids concentrations generally are less than $500 \mathrm{mg} / \mathrm{L}$ in the actively irrigated area near Fallon. Concentrations increase to between 1,000 and greater than $8,000 \mathrm{mg} / \mathrm{L}$ in the areas to the north, south, and east. The highest measured value $(8,390 \mathrm{mg} / \mathrm{L})$ is from a flowing well located in Stillwater Wildlife Management Area (site 43, fig. 3).

Some general conclusions can be made from the above information. Recharge areas for the intermediate aquifers are in the western and central parts of the basin. Isotopic data and general chemical composition of the water both support this conclusion. The composition is that of a dilute water similar to Carson River water. Ground water in the intermediate aquifers flows to the northeast and south-southeast from the recharge area dissolving minerals along the way. It then discharges into the shallow aquifers, and subsequently undergoes evaporative concentration, causing the observed increase in dissolved-solids concentrations downgradient in the ground-water flow systems. 


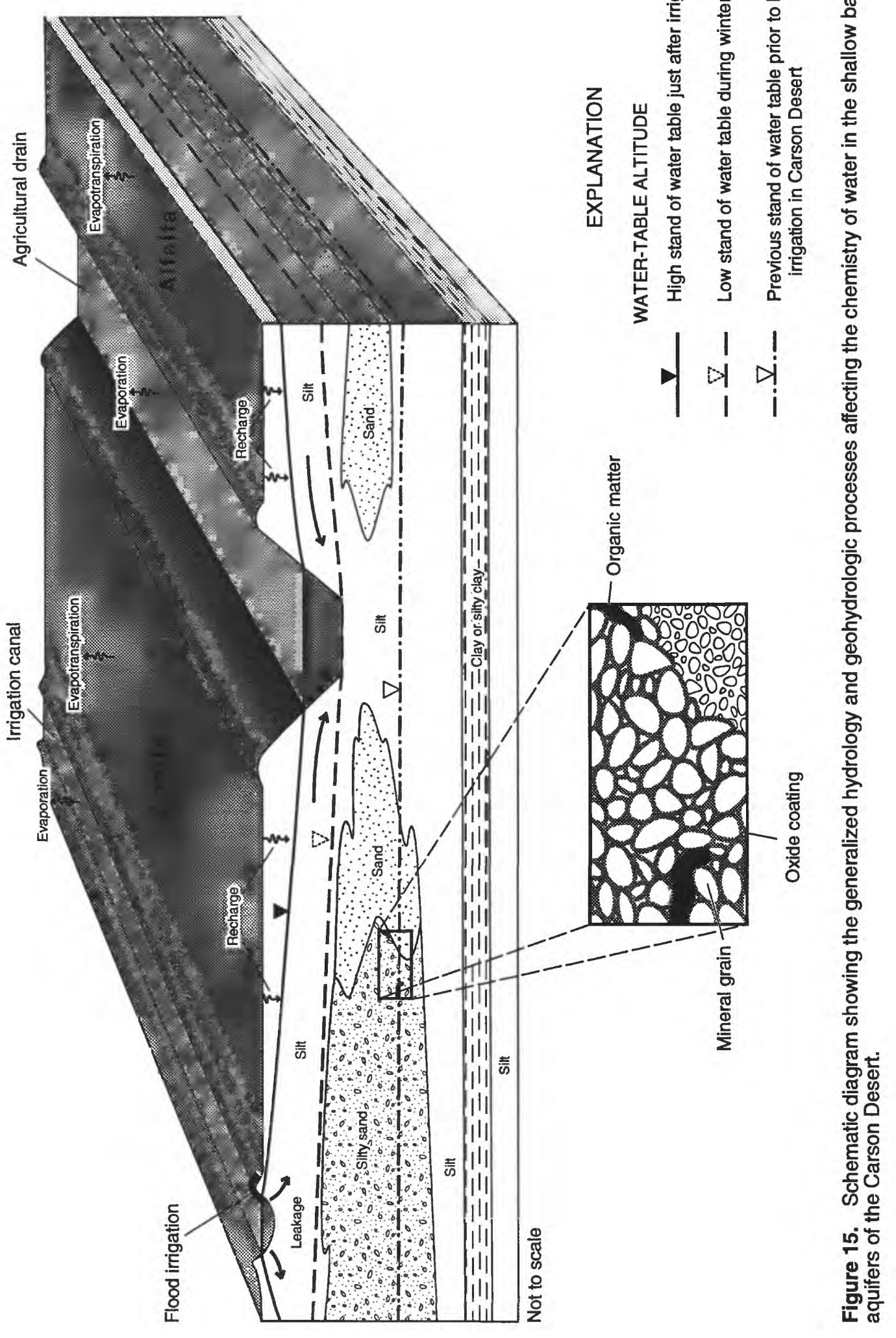


Only one analysis is available for water from the deep aquifers in the Fallon area. This analysis is from a 1,700-ft-deep well southeast of Fallon near the Fallon Naval Air Station. The dominant constituents in the water are sodium, bicarbonate, and chloride; the chemical composition is similar to water from two wells in the intermediate aquifers (sites 150 and 167, fig. 3), both of which are near the well. These data indicate that water compositions in the deep aquifers may be very similar to those of the intermediate aquifers in this part of the basin. Thus, the definition of the deep aquifers may just be an arbitrary one. The deep aquifers are not discussed further in this report.

The dominant ions in water from the basalt aquifer are sodium, bicarbonate, and chloride (fig. 12). The $\mathrm{pH}$ ranges from 9.0 to 9.4 with a median $\mathrm{pH}$ of 9.3 . The dissolved-solids concentration of ground water from the basalt aquifer ranges from 315 to $670 \mathrm{mg} / \mathrm{L}$ and has a median value of $580 \mathrm{mg} / \mathrm{L}$ (fig. 12). The highest dissolved-solids concentration was measured in water samples at site 52 (fig. 3) and the lowest was measured in the Fallon-Mori well (site 127, fig. 3). These values indicate that the ground water may be dissolving minerals in the rock as it flows along a northeasterly path, supporting the evidence from the weak ground-water gradient described earlier. These wells, according to Glancy (1986), can tap water from both the intermediate and basalt aquifers. Other wells completed in the basalt aquifer have water of fairly uniform composition.

Ground-water samples from the thermal aquifers have a sodium chloride composition with a moderate (median dissolved solids of about $4,000 \mathrm{mg} / \mathrm{L}$ ) salinity.
The high concentrations of silica (as high as $290 \mathrm{mg} / \mathrm{L}$ ) and fluoride (as high as $5.5 \mathrm{mg} / \mathrm{L}$ ) are indicative of thermal water. Samples available from the thermal aquifers, which are at the distal end of the flow system in the basin, possibly reflect the end products of reaction between ground water and aquifer material.

More than one-half of the sites sampled (108 of 177) in the Carson Desert have ground water that exceeds the SMCL of $500 \mathrm{mg} / \mathrm{L}$ for dissolved solids. Many of the samples from these same sites also exceed the SMCL of $400 \mathrm{mg} / \mathrm{L}$ for chloride. The areal distribution of the sites that exceed SMCL's is shown in figure 16. Many of the wells that have water exceeding these standards are not used as sources of public supply and are located in the peripheral areas of the basin (Carson Lake, Stillwater, and Upsal Hogback areas). Magnesium (150 mg/L) and sulfate $(500 \mathrm{mg} / \mathrm{L})$ concentrations exceed SMCL's at 36 and 48 sites, respectively (table 4). Again, these sites generally are not used for public supply and are the same sites where dissolved solids and chloride exceed standards. Fluoride exceeded the MCL of $4.0 \mathrm{mg} / \mathrm{L}$ at 6 sites (fig. 17) and the SMCL of $2.0 \mathrm{mg} / \mathrm{L}$ at 32 sites. Three of these well sites tap thermal water and the other 3 sites are in the shallow or intermediate aquifers. Nitrate concentrations in ground water are greater than the $10 \mathrm{mg} / \mathrm{L} \mathrm{MCL}$ at 3 sites. One of the sites that exceeds nitrate standards is located at the Newlands Agricultural Research Station. This concentration may be related to effluents from septic systems located 250 to $300 \mathrm{ft}$ from the wells. 


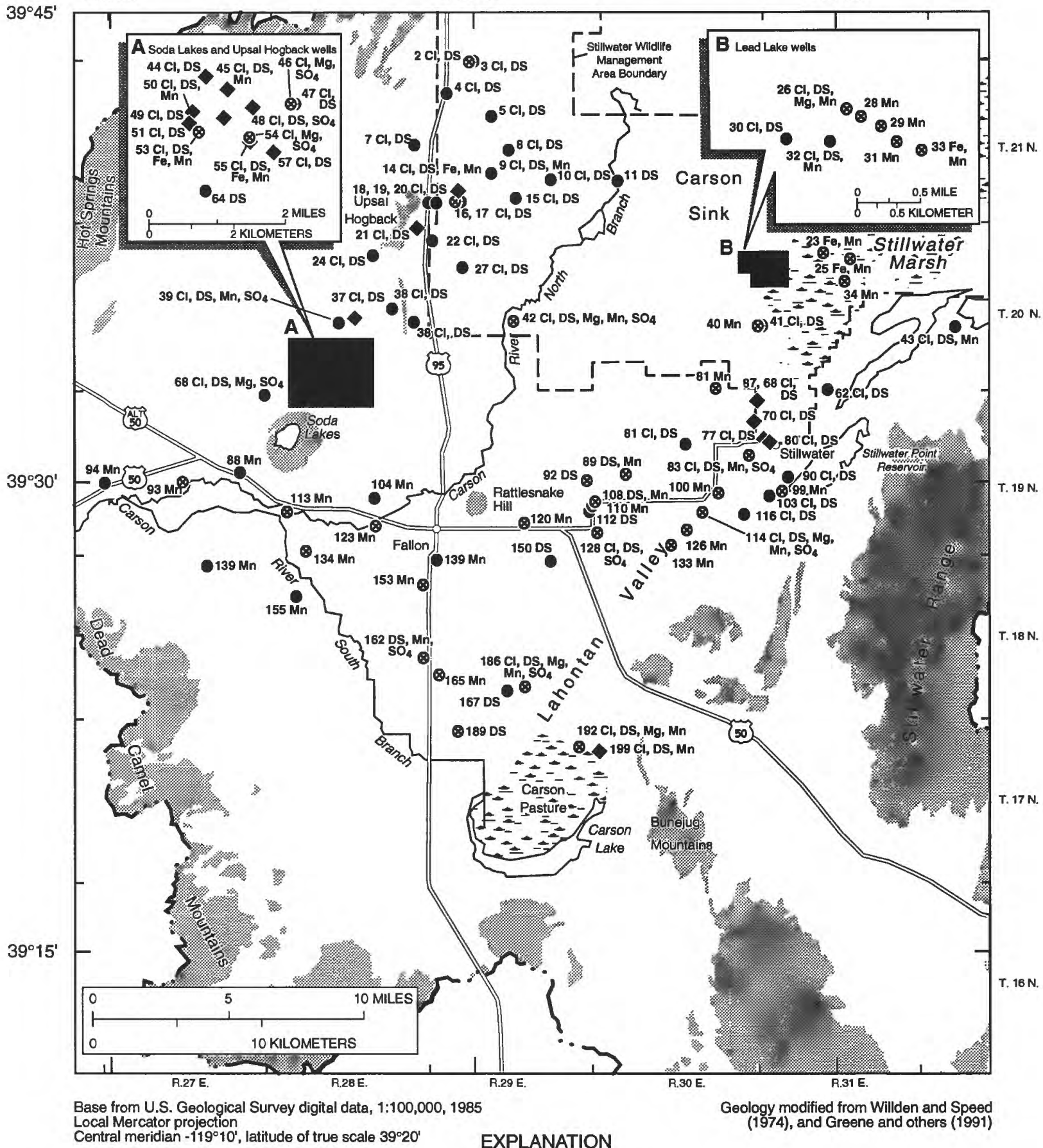

Central meridian $-119^{\circ} 10^{\prime}$, latitude of true scale $39^{\circ} 20^{\prime} \quad$ EXPLANATION

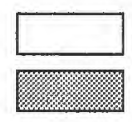

BASIN-FILL DEPOSITS

CONSOLIDATED ROCKS

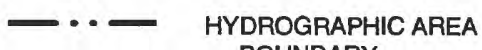
BOUNDARY

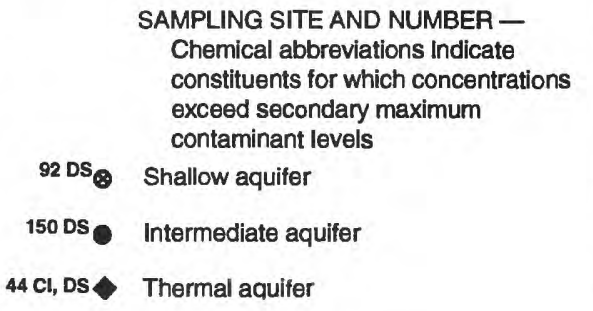

\section{CHEMICAL ABBREVIATIONS AND} MAXIMUM CONTAMINANT LEVEL

CI Chloride (400 milligrams per liter) DS Dissolved sollds (1,000 milligrams per liter)

Fe Iron (0.6 milligram per liter)

Mg Magnesium (150 milligrams per liter)

Mn Manganese (0.1 milligram per liter)

$\mathrm{SO}_{4}$ Sulfate (500 milligrams per liter)

Figure 16. Wells yielding water with concentrations of dissolved constituents that exceed Nevada State drinking-water standards-secondary maximum contaminant levels. 


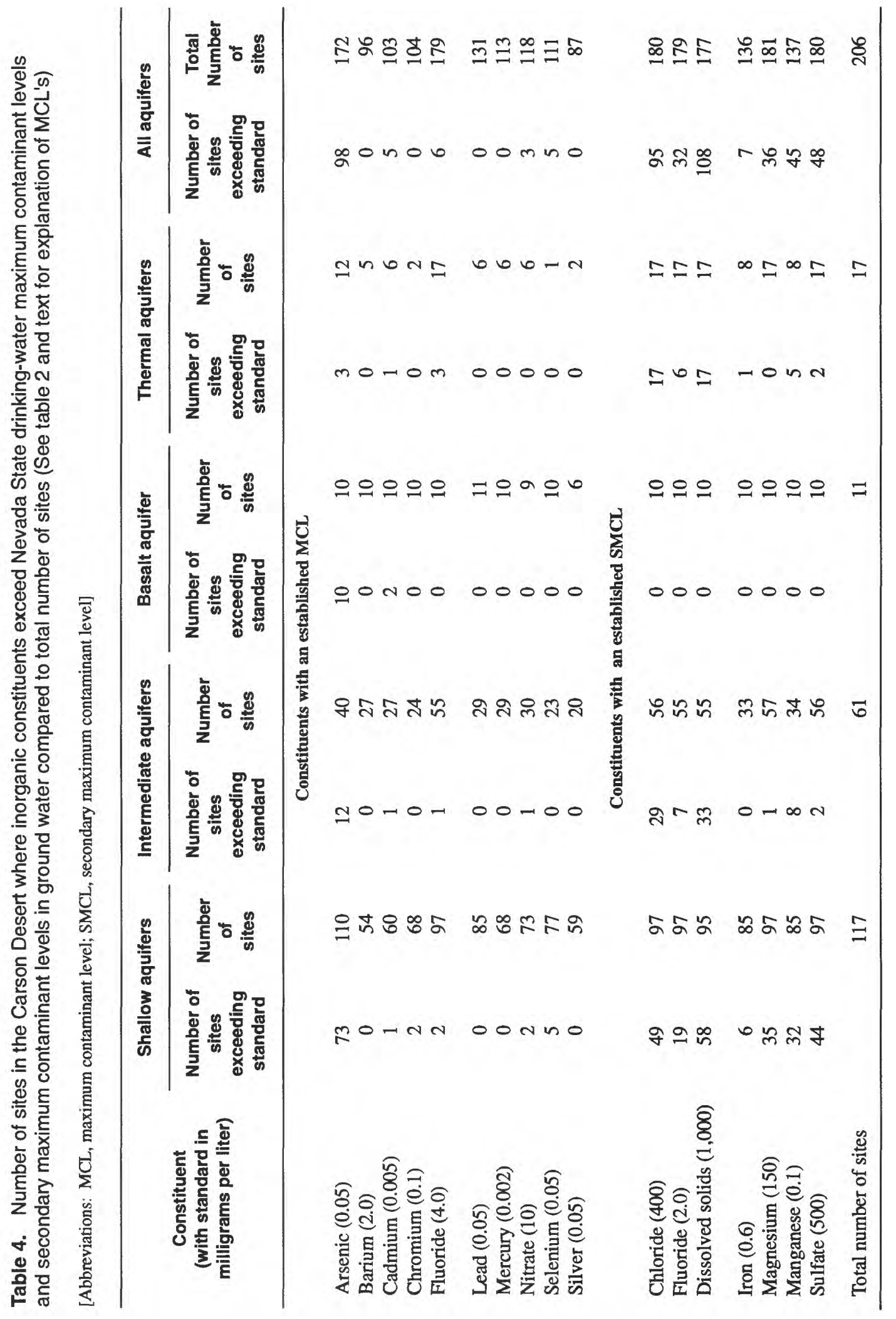




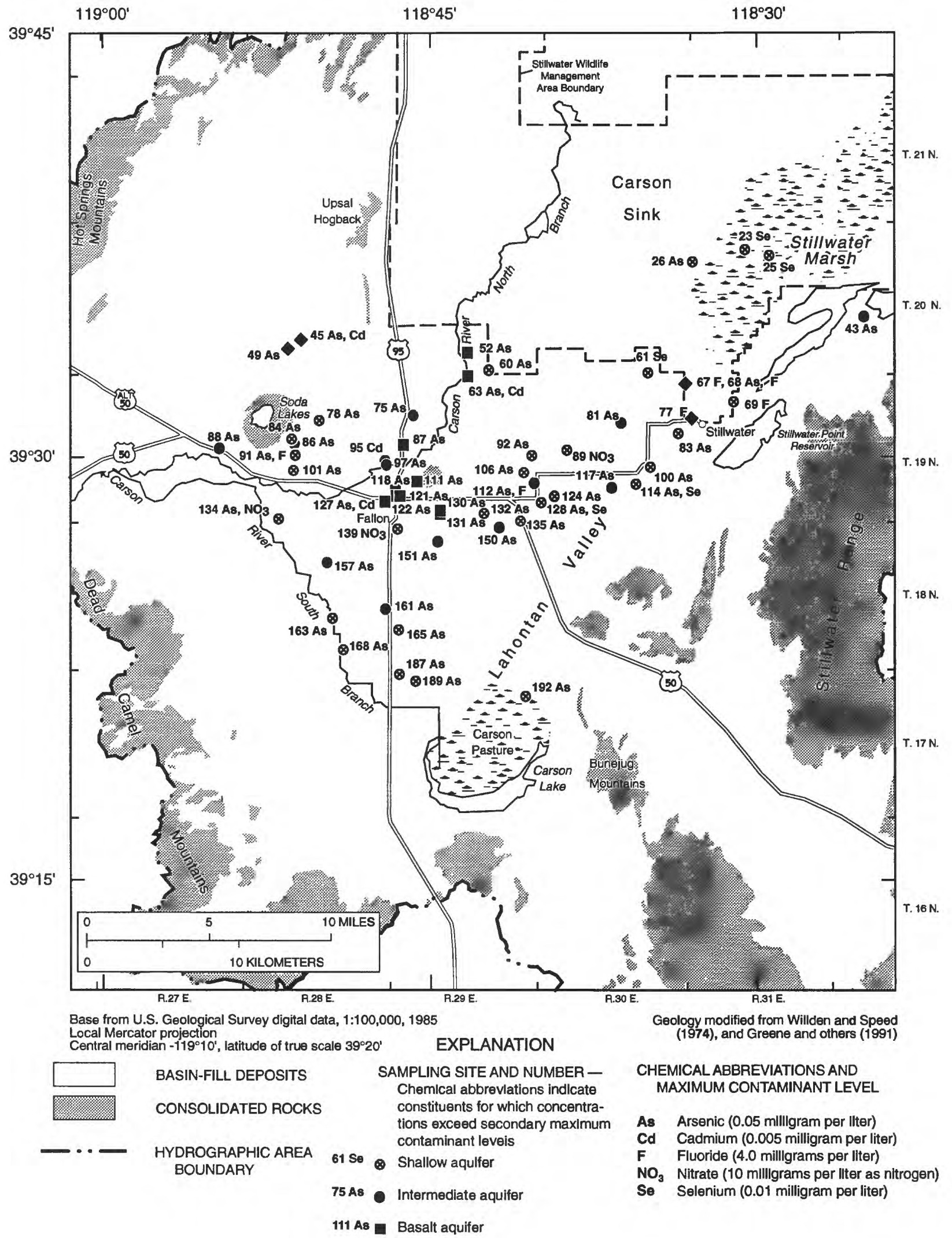

Figure 17. Wells yielding water with concentrations of dissolved constituents that exceed Nevada State drinking-water standards-maximum contaminant levels. 


\section{Processes Affecting Concentrations of Major Constituents}

Ground water in aquifers of the Carson Desert is in contact with sediment derived from intrusive and extrusive igneous, metasedimentary, sedimentary, and metavolcanic rocks in the adjacent mountains and the headwaters of the Carson River in the Sierra Nevada. Concentrations of the major constituents are primarily a result of chemical reactions with the minerals derived from rocks in upland areas and their weathering products. Evapotranspiration also concentrates solutes, particularly for water in the shallow aquifers in the peripheral areas of the basin. Some processes responsible for the observed water quality can be presented as a set of geochemical reactions (referred to as reactions hereafter), commonly termed a geochemical model (referred to as model hereafter). A model for a groundwater system can be evaluated by using a mass-balance approach that generally consists of analyzing chemical and isotopic data for ground water and aquifer matrix, thermodynamic data for phases ${ }^{1}$ of interest (minerals, gases, and amorphous phases), and hydrologic knowledge (Plummer and others, 1983). One common approach is the formulation of a model along a groundwater flow path that yields a different reaction for the various segments of the flow path between the sampling locations. This common approach was used for the Fernley area by Lico (1992), but was not used for ground water in the Carson Desert because sampling locations are generally not along flow paths and the wells do not always draw water from discrete depths because supply wells are open over long vertical intervals. In contrast, the approach used here assumed that the water quality in the basin-fill deposits is a result of a common set of reactions. This approach has led to a model that is consistent with available data. The model described within this report consists of a general set of reactions that result in a water composition that has characteristics similar to those found in the aquifers.

The model is evaluated for consistency with (1) mineralogic data for a limited set of water samples collected in the shallow subsurface in the Carson Desert, (2) the bulk geochemistry of sediments in Carson Desert, (3) the chemical and isotopic composition of the ground water, and (4) thermodynamic calcu-

\footnotetext{
${ }^{1} \mathrm{~A}$ phase is any homogeneous part of water separated from other parts of matter by physical surfaces or boundaries. A phase may be solid, liquid, or gas and may be composed of an element, a compound, or a homogeneous mixture of elements or compounds.
}

lations of mineral equilibrium. Although this approach does not yield a unique model, the model is believed to provide a satisfactory description of the geochemical processes that results in the observed water quality of major constituents.

The mass-balance approach yields unique numerical solutions (if there are any) for a particular set of phases and water-quality data. Formulation of a unique solution requires that the number of phases be equal to the total number of elements and isotopes used in the model. Minerals that have been identified in basin-fill sediments and the basalt of Rattlesnake Hill are included in the models as phases and are listed in table 5. These phases represent a set of probable phases that react with, or precipitate from, the throughflowing ground water. Additional phases included in the model are cation-exchange reactions, carbon dioxide, pyrite, and sodium chloride. Pyrite is an accessory mineral in igneous and metamorphic rocks and is a potential source for sulfate in the ground water. Chloride, with an equivalent amount of sodium, is assumed to enter ground water from fluid inclusions in igneous rock fragments or halite present as evaporite minerals in the sediment.

The mass-balance approach requires that exact mineral compositions be used. For some of the identified minerals an exact chemical composition has not been determined. In general, the chemical formulas used in models for dissolving minerals correspond to compositions for minerals commonly found in the Sierra Nevada - the primary source of sediment for the Carson River. The composition used for plagioclase feldspar corresponds to intermediate andesine with a molar ratio of sodium to calcium of 3:2. Andesine is the mineral most commonly identified in thin sections of sediment from the Carson Desert. A chemical formula for hornblende was used to represent the amphibole mineral group. Biotite, which is common in the sediment of the Carson Desert, is included in the model as an arbitrarily selected composition (table 5). The composition of pyroxene corresponds to the mineral augite-a common mineral in volcanic rocks and the sediment of the Carson Desert. The sodium endmember is used for the clay, beidellite, along with the inclusion of an exchange phase that allows sodium to be released to ground water in exchange for calcium that generally is the divalent cation that has the highest concentrations in the ground water. 
Table 5. Minerals identified and phases included in geochemical models, their composition, and rationale for inclusion in geochemical models of the Carson Desert

\begin{tabular}{|c|c|c|}
\hline $\begin{array}{l}\text { Mineral } \\
\text { or phase }\end{array}$ & Composition & Phase selection rationale \\
\hline Biotite & $\mathrm{KMg}_{0.5} \mathrm{Fe}(\mathrm{II})_{0.5} \mathrm{Al}_{0.5} \mathrm{Fe}(\mathrm{III})_{0.5} \mathrm{Si}_{3} \mathrm{O}_{10}(\mathrm{OH})_{2}$ & Identified in thin section, mostly altered to chlorite. \\
\hline Calcite & $\mathrm{CaCO}_{3}$ & $\begin{array}{l}\text { Ubiquitous; identified in thin section and X-ray diffraction, } \\
\text { present as shell fragments in Lake Lahontan sediments, as } \\
\text { crystal overgrowths, carbonate clastic fragments, and } \\
\text { cavity fillings in basalt. }\end{array}$ \\
\hline Carbon dioxide & $\mathrm{CO}_{2}$ & $\begin{array}{l}\text { Ubiquitous; atmospheric, root-respiration of plants, and } \\
\text { oxidation of sedimentary organic matter. }\end{array}$ \\
\hline Chlorite & $\mathrm{Mg}_{5} \mathrm{Al}_{2} \mathrm{Si}_{3} \mathrm{O}_{10}(\mathrm{OH})_{8}$ & $\begin{array}{l}\text { Common alteration product of feldspars, biotite, pyroxene, } \\
\text { and hornblende as seen in thin section. Presence } \\
\text { confirmed by X-ray diffraction. }\end{array}$ \\
\hline Exchange & $\mathrm{Ca}-\mathrm{Na}$ & $\begin{array}{l}\text { Abundant exchange sites are present in sediment; mainly used } \\
\text { to adjust unknown compositions of beidellite, pyroxene, } \\
\text { hornblende, and biotite. }\end{array}$ \\
\hline Gypsum & $\mathrm{CaSO}_{4} \cdot 2 \mathrm{H}_{2} \mathrm{O}$ & $\begin{array}{l}\text { Present in desert soils; identified by optical petrography near } \\
\text { Stillwater. }\end{array}$ \\
\hline Halite & $\mathrm{NaCl}$ & Common mineral in areas with high evaporation rates \\
\hline Hematite & $\mathrm{Fe}_{2} \mathrm{O}_{3}$ & Present as coatings on iron-bearing minerals. \\
\hline Hornblende & $\mathrm{Ca}_{2} \mathrm{Na}_{0.5} \mathrm{Mg}_{5} \mathrm{Al}_{1.8} \mathrm{Si}_{7} \mathrm{O}_{22}(\mathrm{OH})_{2}$ & Identified in thin section; possible dissolution. \\
\hline Illite & $\mathrm{K}_{0.6} \mathrm{Mg}_{0.25} \mathrm{Al}_{2.3} \mathrm{Si}_{3.5} \mathrm{O}_{10}(\mathrm{OH})_{2}$ & Presence confirmed by X-ray diffraction. \\
\hline $\begin{array}{l}\text { Plagioclase feldspar } \\
\text { intermediate } \\
\text { andesine }\end{array}$ & $\mathrm{Na}_{0.6} \mathrm{Ca}_{0.4} \mathrm{Al}_{1.4} \mathrm{Si}_{2.6} \mathrm{O}_{8}$ & $\begin{array}{l}\text { Present as detrital grains and as components in volcanic and } \\
\text { sedimentary lithic fragments. Compositions range from } \\
\text { albite to labradorite. }\end{array}$ \\
\hline Potassium feldspar & $\mathrm{KAlSi}_{3} \mathrm{O}_{8}$ & $\begin{array}{l}\text { Identified in thin section and by X-ray diffraction. Slightly } \\
\text { altered to chlorite and sericite. }\end{array}$ \\
\hline Pyrite & $\mathrm{FeS}_{2}$ & Present in volcanic rock fragments. \\
\hline Pyroxene augite & $\mathrm{Ca}_{0.5} \mathrm{Mg}_{0.5} \mathrm{Fe}_{0.5} \mathrm{Al}_{0.5} \mathrm{Si}_{2} \mathrm{O}_{6}$ & Identified in thin section; possible dissolution (ragged edges). \\
\hline Sericite & $\mathrm{KAl}_{2}\left(\mathrm{AlSi}_{3} \mathrm{O}_{10}\right)(\mathrm{OH})_{2}$ & $\begin{array}{l}\text { Identified in thin section, common alteration product of } \\
\text { plagioclase. }\end{array}$ \\
\hline Silica & $\mathrm{SiO}_{2}$ & $\begin{array}{l}\text { Quartz, chalcedony, and glass shards are present in thin } \\
\text { section. }\end{array}$ \\
\hline $\begin{array}{l}\text { Smectite sodium } \\
\text { beidellite }\end{array}$ & $\mathrm{Na}_{0.33} \mathrm{Al}_{2.33} \mathrm{Si}_{3.67} \mathrm{O}_{10}(\mathrm{OH})_{2}$ & $\begin{array}{l}\text { Presence confirmed by X-ray diffraction, exact composition } \\
\text { unknown, some mixed-layer clays (smectite-illite) also } \\
\text { present. }\end{array}$ \\
\hline
\end{tabular}


In general, water in aquifers beneath the Carson Desert contains little or no measurable dissolved oxygen. Concentrations of dissolved oxygen are less than $1.0 \mathrm{mg} / \mathrm{L}$ in 71,95 , and 83 percent of samples collected from the shallow, intermediate, and basalt aquifers, respectively. This indicates that oxidation-reduction (redox) reactions may be important in the ground water. Oxygen-consuming reactions are most likely occurring in the upper parts of the shallow aquifers that have not been evaluated here. Lico and others (1987) have described the important redox reactions taking place in the shallow aquifers. The general absence of measurable nitrite and sulfide odor (except for a few samples) indicate that chemical reduction of nitrogen and sulfur is not an important process in the ground water, although microbially mediated redox reactions (such as sulfate reduction) may be occurring, most likely with the sulfide being precipitated as iron sulphide on the solid-phase aquifer material. Massbalance reactions in this report do not include redox reactions.

The stable-isotope composition of dissolved inorganic sulfur and carbon can be used to evaluate the feasibility of specific proposed reactions. The differences in the stable-isotope composition of dissolved inorganic carbon and sulfur in the Carson Desert can be a result of several factors including (1) variation in the amount or isotopic composition of minerals containing sulfur and carbon that are dissolved by the ground water; (2) mineral precipitation; (3) microbial processes, such as sulfate reduction; and (4) differences in the isotopic composition of recharge water.

The sulfur-isotope composition of water with sulfate concentrations less than about $50 \mathrm{mg} / \mathrm{L}$ is generally heavier (more positive) in Carson Desert than the composition in samples with higher concentrations of sulfate (fig. 18). The variation of the low sulfate water probably is caused by microbial sulfate reduction and compositional differences in the rocks that compose the basin-fill sediments. Microbial reduction of sulfate leaves the isotopically heavier sulfate in solution and reduces the isotopically lighter sulfate to sulfide. Abiotic (without the aid of microbes) reduction of sulfate, which probably does not occur at the conditions present in the aquifers, would not fractionate sulfur at temperatures below about $50^{\circ} \mathrm{C}$ (Ohmoto and Rye, 1979, p. 539). The sulfur-isotope composition of water with sulfate concentrations less than $50 \mathrm{mg} / \mathrm{L}$ is heavier than the range found in granitic rocks in the circum-Pacific by Ishihara and Sasaki (1989) and that found in Carson and Eagle Valleys farther upstream in the Carson River Basin (Welch, 1994). The isotopic composition of dissolved sulfate in the aquifers probably is not affected by mineral precipitation because sulfate concentrations are well below concentrations that could form common sulfur-bearing minerals such as gypsum except in the shallow basin-fill aquifer near Stillwater Marsh.

As the chloride concentration increases, the sulfate concentration increases linearly for groundwater samples from the shallow aquifer (fig. 18). The isotopic composition of sulfate in water from the shallow aquifers remains relatively constant (from 4 to 10 permil) as sulfate concentrations increase indicating either evaporative concentration or dissolution of a sulfate-containing phase that has an isotopic composition between 4 and 10 permil. Sulfate in water samples from wells in the intermediate aquifer has a much larger range of isotopic compositions (from -5 to 33 permil). There are possible explanations for this observation, (1) evaporative concentration of ground water is enriching chloride and sulfate, but the sulfate concentrations are being lowered by microbial sulfate reduction, (2) evaporative concentration of ground water enriches chloride and sulfate, but the sulfate is being removed from solution by precipitation of gypsum, and (3) a chloride-containing salt is being dissolved. Precipitation of gypsum can be ruled out because most water samples in the intermediate aquifers are undersaturated with gypsum and it could not be precipitated. It is unlikely that a chloride-containing salt is dissolving in high enough quantities to produce the observed concentrations. The sulfur-isotope composition of dissolved sulfate in water from the intermediate and basalt aquifers indicates that the two aquifers have the same source of sulfur and that sulfate reduction is occurring in the intermediate aquifers. Abundant dissolved organic carbon (table 3 ) in the intermediate aquifers provides ample amounts of carbon for the reaction:

$$
2 \mathrm{CH}_{2} \mathrm{O}+\mathrm{SO}_{4}^{2-} \Rightarrow \mathrm{H}_{2} \mathrm{~S}+2 \mathrm{HCO}_{3}^{-}
$$



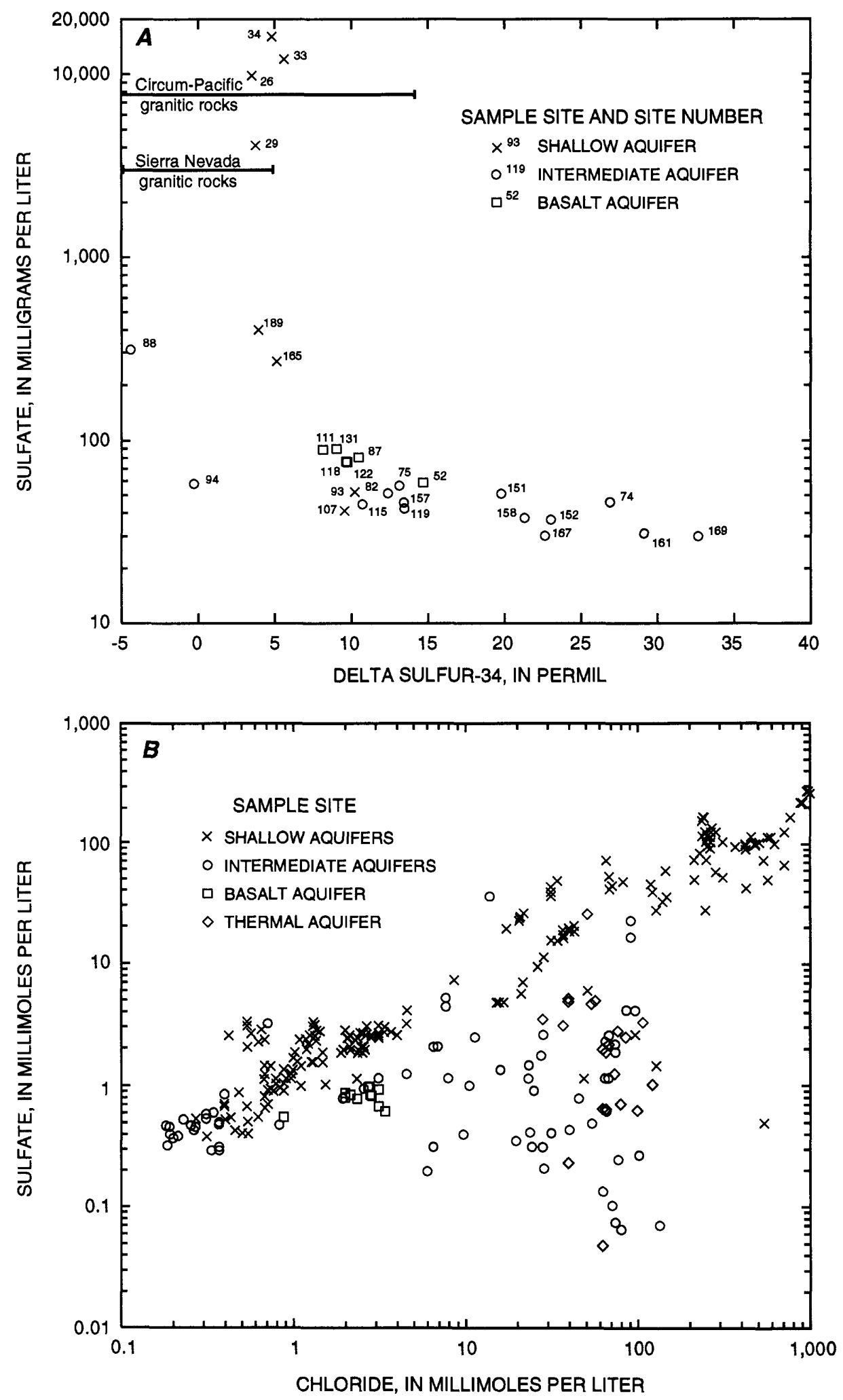

Figure 18. Relation between the concentration of sulfate and $A$, the stable-isotope composition of sulfur in sulfate; and $B$, chloride in ground water in the Carson Desert. 
The stable-isotope composition of carbon in ground water is affected by the composition of the different sources of carbon. Much of the carbon enters ground water as dissolved bicarbonate in the recharge water or in the form of dissolved $\mathrm{CO}_{2}$ as the water passes though the root zone. The carbon-isotope composition of the Carson River (recharge water) has not been measured, but water samples from the Walker and Truckee Rivers have been. Average ${ }^{13} \mathrm{C}$ values for these two rivers are -10.1 permil (range from -11.7 to -9.3 for 15 samples) and -10.5 permil (range of -11.1 to -9.6 for 9 samples) (L.V. Benson, U.S. Geological Survey, written commun., 1992). One water sample from an irrigation ditch near Fallon, reported by Lico and others (1987), has a ${ }^{13} \mathrm{C}$ value of -4.3 permil. Rowe and others (1991) reported a water sample having a ${ }^{13} \mathrm{C}$ value of -9.6 permil from the Truckee Canal near Fernley. The carbon-isotope composition of $\mathrm{CO}_{2}$ in the root zone has not been determined in the study area, but may be estimated based on the composition in ground water and studies of carbon in the unsaturated zone elsewhere in the Great Basin (see below). The carbon-isotope composition of ground water in the unsaturated zone can be controlled by equilibrium with atmospheric and plant-respired $\mathrm{CO}_{2}$. The isotopic composition of plant-respired $\mathrm{CO}_{2}$ is primarily dependent upon metabolic pathways of plant biomass on the land surface. Most plants in the Great Basin follow one of two photosynthetic pathways (Calvin cycle, $\mathrm{C}_{3}$ pathway or Hatch-Slack cycle, $\mathrm{C}_{4}$ pathway), each of which results in a distinct carbonisotope composition of the biomass (Cerling, 1984). The carbon-isotope composition of $\mathrm{CO}_{2}$ respired by plants is similar to the composition of the plant biomass (Deines, 1980). In the Headwaters Area of the Carson River Basin, most native vegetation, including pines and firs, follow the $\mathrm{C}_{3}$ pathway (Quade and others, 1989, table 2). The carbon-isotope composition of $\mathrm{CO}_{2}$ generated by $\mathrm{C}_{3}$ pathway plants averages about -27 permil (Deines, 1980; Cerling, 1984). Plants following the $\mathrm{C}_{4}$ pathway, such as Atriplex (saltbrush), are present in the Carson Desert and yield a carbonisotope composition of about -13 permil (Deines, 1980 and Cerling, 1984). As a result of areal differences in the types of vegetation, the $\mathrm{CO}_{2}$ in soils has a variable isotopic composition that has been shown to range from about -20 to -12 permil for an area with $C_{3}$ and $\mathrm{C}_{4}$ vegetation in southern Nevada (Quade and others, 1989).
Dissolution of carbonate minerals is a second possible source of inorganic carbon. Calcite (and possibly other carbonate minerals) is present as shell fragments in the Pleistocene Lake Lahontan sediment (shallow aquifers). These shell fragments generally do not show evidence of dissolution, instead they commonly are coated with overgrowths of calcite precipitated from the ground water (Lico, 1992). Other calcite sources are present as caliche in the soil zone, ancient caliche layers buried in the shallow aquifers, and secondary fracture and vug fillings in the basalt aquifer. The carbon-isotope composition of calcite sources is not well known. Eight sediment samples from the shallow aquifers were analyzed for their carbonisotope composition. The samples range from -6.8 to 0.9 permil and have an average value of -1.37 permil. Secondary calcite (caliche) from unsaturated zones in southern Nevada has a carbon-isotope composition of -8 to 0 permil (Quade and others, 1989). Sedimentary and dissolved organic matter can supply carbon to the total dissolved inorganic carbon by microbial sulfate reduction (eq. 2). The carbon-isotope composition of organic material in 11 sediment samples from the shallow aquifers ranges from -25.2 to -22.4 permil and has an average value of -23.7 permil.

The trend in carbon-isotope composition of dissolved bicarbonate in the intermediate aquifers indicates dissolution of a few millimoles of calcite that has a composition somewhat heavier than -6 permil (fig. 19). The most dilute water samples have carbonisotope compositions similar to those found in water that is in equilibrium with $\mathrm{CO}_{2}$ in the soil zone where $\mathrm{C}_{4}$ plants are present. This dilute water may represent the composition of recharge for the intermediate aquifers. Most of the shallow aquifer water samples from the irrigated area near Fallon have carbon-isotope compositions that range from -15 to -11 permil, indicative of a $\mathrm{CO}_{2}$ source from $\mathrm{C}_{4}$ plants. Ground-water samples from the shallow aquifers in the discharge areas (Carson Pasture and Stillwater Marsh) have carbonisotope compositions that range from -8 to -5 permil. This water evolved from the intermediate aquifers and has a carbon-isotopic composition that remains relatively constant; the dissolved inorganic carbon concentration changed more than four-fold. Evaporative concentration of the ground water is the most likely explanation for this observed relation. 


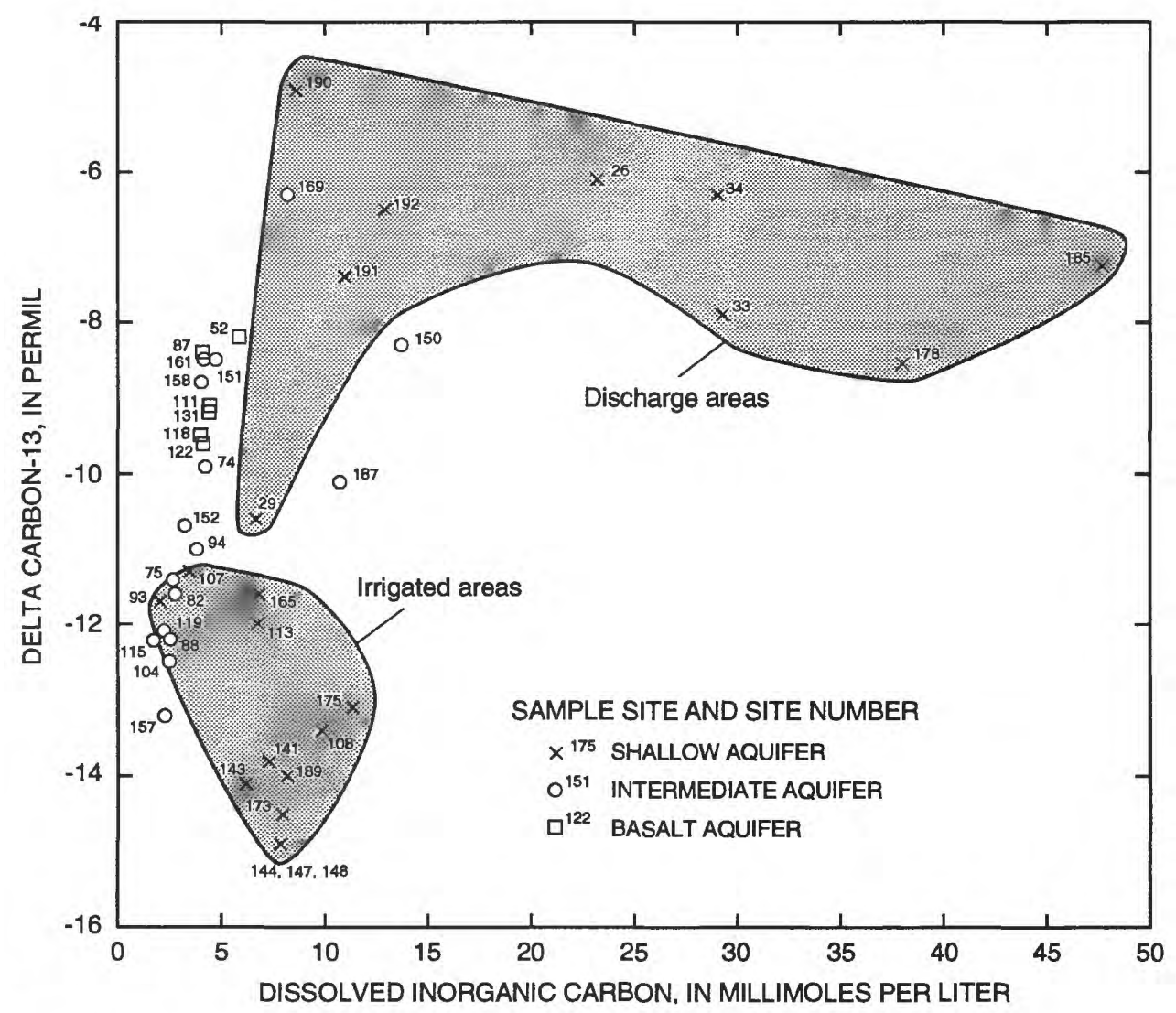

Figure 19. Relation between the stable-isotope composition of carbon and the concentration of dissolved inorganic carbon in ground water in the Carson Desert.

The inclusion, in the reactions, of the exchange of sodium for calcium is consistent with the use of the sodium beidellite clay mineral in the reactions. Although the cation composition of beidellite is not known, calcium and sodium are both expected to be present in beidellite. The inclusion in the reactions of a phase simulating exchange represents, at least in part, a correction for the uncertainty in the cation composition of beidellite. Additionally, the exchange is consistent with the release of sodium for calcium from phases that exchange cations, such as most clay minerals, and phases such as sedimentary organic matter and oxide coatings which are commonly found in sediments (Jenne, 1968). A divalent cation, such as calcium, can exchange with a monovalent cation, such as sodium, when a phase is formed in a dilute water and then subsequently comes in contact with more concentrated water with the same major cation ratios (Drever, 1982, p. 82-85). Exchange will proceed even if the ratio of the cations in the dilute and more concentrated water is the same (assuming the equilibrium constant for exchange on the solid phase remains constant). Therefore, a clay mineral formed in equilibrium with water in the upland part of the Carson River Basin (in equilibrium with dilute ground or surface water), transported downstream by the Carson River, and becoming part of the basin-fill aquifer will release sodium if the ground water has greater concentrations of sodium and calcium than the surface water. This will occur even if the ratio of these two cations in water is the same in the two parts of the Carson River Basin. Because of lower concentrations of potassium and magnesium, the effect on the reactions caused by excluding the other exchange reactions is probably minor compared to other uncertainties in the overall reaction.

General mass-balance reactions were constructed for five ground-water segments that include the different aquifers in the Carson Desert. These "reaction segments" are:

1. Shallow basin-fill aquifers near Fallon to intermediate basin-fill aquifers near Fallon; 
2. Shallow basin-fill aquifers near Fallon to basalt aquifer;

3. Intermediate basin-fill aquifers near Fallon to basalt aquifer;

4. Intermediate basin-fill aquifers near Fallon to intermediate basin-fill aquifers near Soda Lakes-Upsal Hogback; and,

5. Intermediate basin-fill aquifers near Fallon to shallow basin-fill aquifers near Carson Lake (Carson Pasture).

Eleven phases may be included in each individual reaction because eleven constituents (sodium, calcium, magnesium, potassium, dissolved inorganic carbon, chloride, sulfate, silica, iron, aluminum, and the stableisotope composition of carbon) are included in the reactions. The mineralogic phases considered for the reactions, their chemical compositions, and rationale for their selection are listed in table 5. The massbalance approach does not yield a unique solution in a system like that found in Carson Desert because the number of possible reacting phases is greater than the number of "elements." Each reaction starts with the chemistry of a representative water from the aquifer where the water originates. This composition was chosen by evaluating chemical, isotopic, and hydrologic data for the aquifers. Reactions were designed for changes in composition from these initial waters to all samples available of the final water. Four mineral phases were "forced" to be in each model on the basis of visual observations of thin sections made from the sediment or basalt. These minerals are plagioclase (intermediate andesine composition), augite, calcite, and sodium beidellite (table 5).

All possible combinations of the phases indicated in table 5 were evaluated for each reaction segment using the computer program BALANCE (Parkhurst and others, 1982). The program solves a set of simultaneous equations and yields the stoichiometric coeffcients for chemical mass-balance reactions. For each of the general reactions, the average amounts of mass input and output for each unique combination of phases was calculated. Specific combinations of minerals, termed "specific reactions," that can form the observed water quality were retained for further consideration if total mass transfer was less than twice (five times for reaction segment 2 ) the average dissolved-solids con- tent in ground water. The limitation on the total mass transfer is imposed in order to demonstrate that reactions with relatively modest amounts of dissolution and precipitation can explain the observed water quality. Linear combinations of the specific reactions represent additional numerically valid reactions as well. For instance, the sum of one-half the mass transfer of each of the phases from two other specific reactions represents a valid reaction that meets the second criterion. A reaction consisting of a combination of mostly an "accepted" reaction combined with a small amount of a "rejected" reaction is therefore a satisfactory solution to a general reaction. Two of the reaction segments did not fit the constraints of the reactions as defined. One of these reaction segments (segment 4 above), had only 1 sample out of 20 that fit the 9 identified reactions for that segment. The other reaction segment (segment 5 above), had one reaction that fit 5 of 15 samples. The absence of acceptable reactions for this step indicates that other processes, most likely mixing of ground water with irrigation water, are occurring. These two reaction segments (4 and 5) were deleted from evaluation in the subsequent discussion of possible geochemical reactions occurring in the ground-water system of the Carson Desert.

Criteria were selected in order to retain specific reactions that are numerically possible and compatible with both the observed mineralogy and general groundwater quality. An evaluation of the resulting set of specific reactions indicates whether or not a general model describing the major reactions is a satisfactory representation of the processes that lead to the observed ground-water quality. This overall approach generally cannot be used to accept or reject minerals in a proposed general model, but may give information about the relative amounts of input from the various phases and provide a basis for accepting or rejecting a general model.

The BALANCE initial-water concentrations for the three reaction segments are the observed concentrations in ground water, except for aluminum. Aluminum concentrations are generally low $(10 \mu \mathrm{g} / \mathrm{L}$ or less $)$ in ground water with $\mathrm{pH}$ values in the range found for Carson Desert, so that the aluminum concentrations were set to zero. The compositions of the initial waters are listed in table 6. 


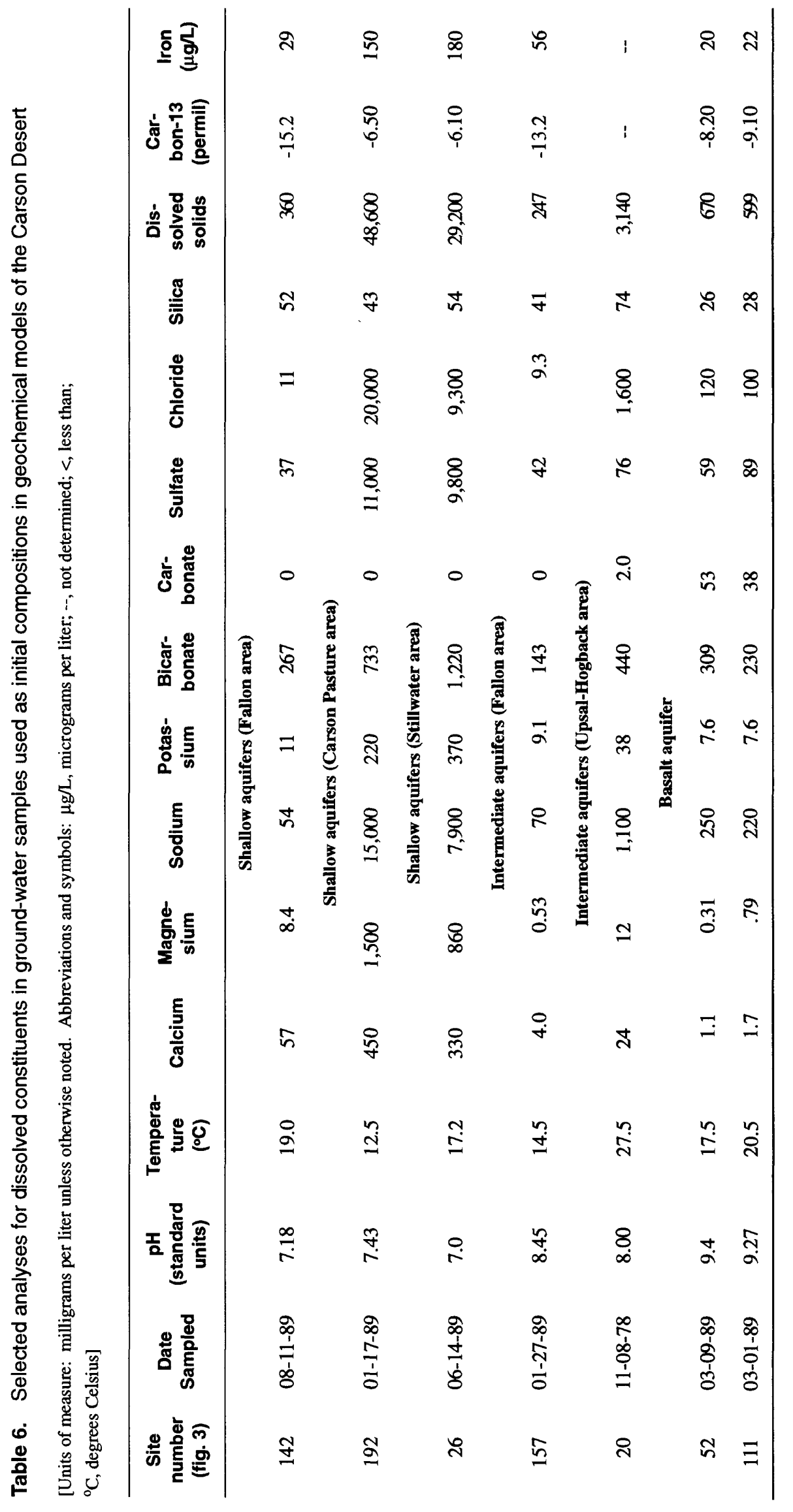


Median values for mass transfer of minerals for the three reaction segments are indicated in figures $20 \mathrm{~A}-F$. The amounts of mass transfer shown in the figures is the molar (atomic) mass contributed by the phases and not the mole fraction for each phase that allows comparison with the molar concentrations in ground water. Positive values indicate dissolution and negative values indicate precipitation. For each of the reaction segments, the reactions have some broad similarities in that (1) plagioclase feldspar represents a major source of dissolved solids, (2) release of sodium to solution by cation exchange for calcium is a common factor in all reactions, (3) sodium beidellite is formed in all reactions, and (4) mass transfer of $\mathrm{CO}_{2}$ is relatively small-in all cases no more than 1 millimole per liter (mmol/L).

Three reactions were developed for the segment representing changes in water quality between the shallow basin-fill aquifers and the intermediate basin-fill aquifers near Fallon (reaction segment 1; fig. $20 A$ and $B$ ). As in all reaction segments in the Carson Desert, plagioclase, cation exchange, and sodium beidellite are the major reactants and products of reactions between sediments and water. Calcite is included in the reactions and represents a small fraction of the total mass transferred in any one reaction (less than $0.5 \mathrm{mmol} / \mathrm{L}$ ). One reaction in segment 1 allows for precipitation of a small amount of calcite $(0.23 \mathrm{mmol} / \mathrm{L})$, another reaction allows for dissolution of about $0.5 \mathrm{mmol} / \mathrm{L}$, and the third allows for precipitation of a minute amount $(0.006 \mathrm{mmol} / \mathrm{L})$. Sodium chloride has median values that comprise a large part of the total amount of mass transfer, with values that range from 15 to $19 \mathrm{mmol} / \mathrm{L}$. Although evaporation was not included in the reaction, sodium chloride probably represents concentration of the ground water by either evaporation or dissolution of salts precipitated in the unsaturated zone as the soils desiccate and is common in all reactions, especially those involving the shallow aquifers. Silica is precipitated in small amounts in two of the reactions (less than $0.7 \mathrm{mmol} / \mathrm{L}$ ). Because any linear combination of the reactions also represents valid reaction of this segment, the data displayed in figure 20 indicate that an overall reaction, which includes all of the indicated phases, is consistent with the observed concentrations of major constituents.

The mass transfers for the reactions occurring along reaction segment 2 (shallow basin-fill aquifers near Fallon to the basalt aquifer) are indicated in figure $20 C$ and $D$. The amounts of precipitation and dissolution indicated by the seven reactions are broadly similar to the amounts estimated by the set of reactions for segment 1. Plagioclase is the major mineral that dissolves in all reactions between 3 and $4 \mathrm{mmol} / \mathrm{L}$. Sodium beidellite is formed in all reactions as a direct product of incongruent dissolution of plagioclase. Amounts of sodium beidellite formed are between about 1 and $3.3 \mathrm{mmol} / \mathrm{L}$. Cation exchange, involving about $4 \mathrm{mmol} / \mathrm{L}$ of mass transfer, is present in all reactions for this reaction segment. The amounts of $\mathrm{CO}_{2}$ indicated by all the reactions are relatively small (about $0.25 \mathrm{mmol} / \mathrm{L}$ ). All reactions indicate that calcite precipitates (about $0.5 \mathrm{mmol} / \mathrm{L}$ ). Silica precipitates in three of seven reactions (less than $0.9 \mathrm{mmol} / \mathrm{L}$ ) and dissolves in one reaction $(0.35 \mathrm{mmol} / \mathrm{L})$. Small amounts of gypsum and sericite also are dissolving. Illite is forming in the aquifer as indicated in six of seven reactions.

Reaction segment 3 is characterized by the six possible reactions shown in figure $20 E$ and $F$. Only one-half of the samples are explained by four of the six reactions. Plagioclase, calcite, and carbon dioxide are common to all reactions and are the major components dissolving in these reactions. Cation exchange mass transfer involves between 3 to $3.5 \mathrm{mmol} / \mathrm{L}$. Sodium beidellite is the major reaction product forming in all reactions (between 0.25 and $3.3 \mathrm{mmol} / \mathrm{L}$ ). Silica precipitates in four of six reactions in small amounts ( 0.44 to $0.74 \mathrm{mmol} / \mathrm{L})$. Small amounts of pyrite, sericite, hematite, and illite also are involved in the reactions controlling the major-element chemistry of these waters. Between 4.6 and $5.0 \mathrm{mmol} / \mathrm{L}$ of sodium chloride dissolved in these reactions indicates evaporation is occurring along this reaction segment or possibly sodium chloride-rich fluid inclusions are being mixed with the water as minerals in the basalt dissolves.

The mass-balance reactions indicated by the data shown in figures $20 A-F$ are consistent with the thermodynamic state of the ground water. Thermodynamic data used for the phases in the model are from the computer program WATEQ4F (Ball and others, 1987). Thermodynamic data, and hence calculations involving them, are not available for some of the mineral phases included in the model described above. Saturation indices for those minerals that have thermodynamic data are listed in table 7 . Chemical activity diagrams, shown in figure 21 , indicate the following conditions: 

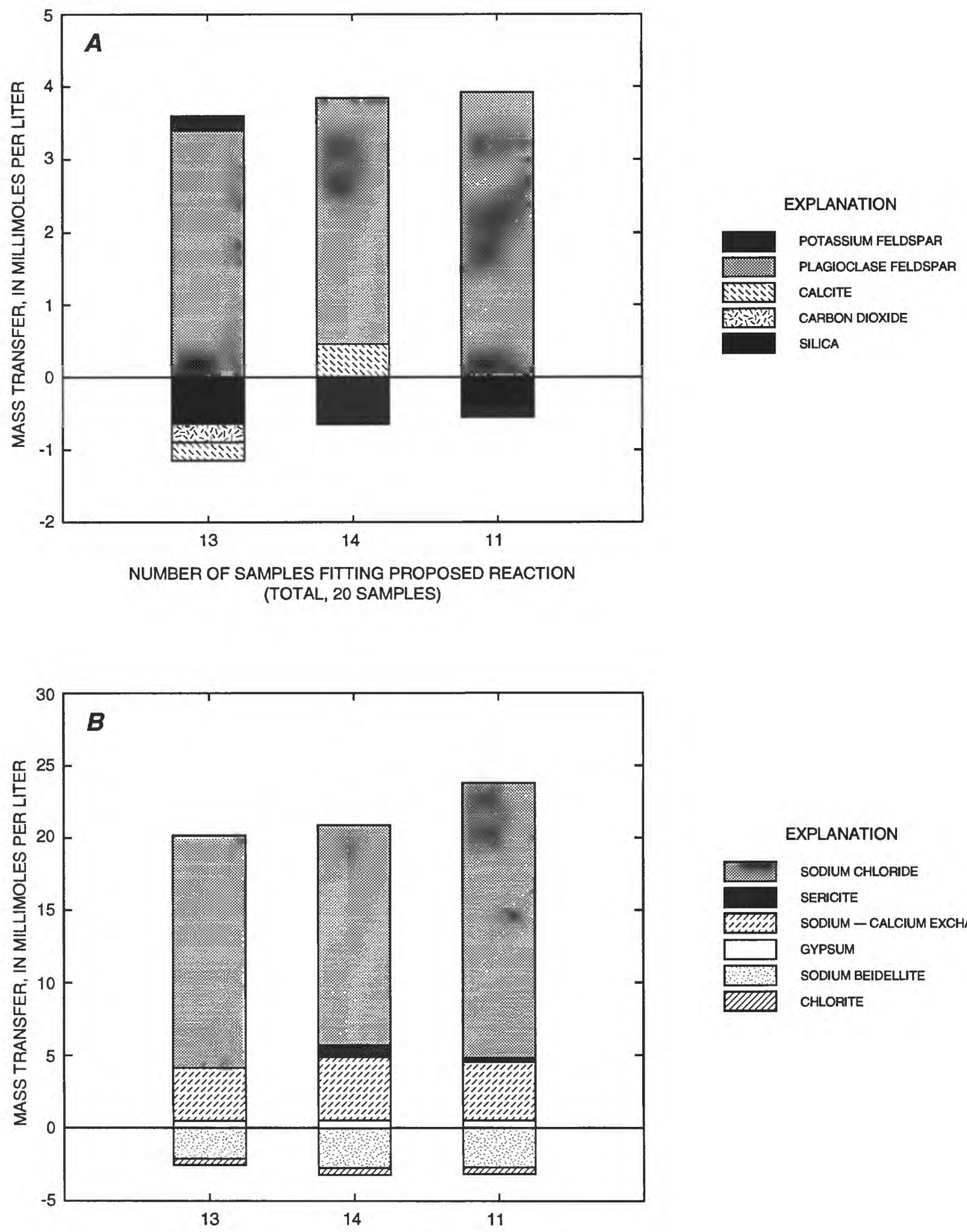

\section{EXPLANATION}

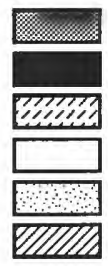

SODIUM CHLORIDE SERICITE

SODIUM - CALCIUM EXCHANGE GYPSUM

SODIUM BEIDELLITE

CHLORITE

NUMBER OF SAMPLES FITTING PROPOSED REACTION

(TOTAL, 20 SAMPLES)

Figure 20. Median amounts of mass transfer for geochemical reactions. $A$ and $B$, shallow basin-fill aquifers near Fallon to intermediate basin-fill aquifers near Fallon; $C$ and $D$, shallow basin-fill aquifers near Fallon to basalt aquifer; $E$ and $F$, intermediate basin-fill aquifers near Fallon to basalt aquifer. 

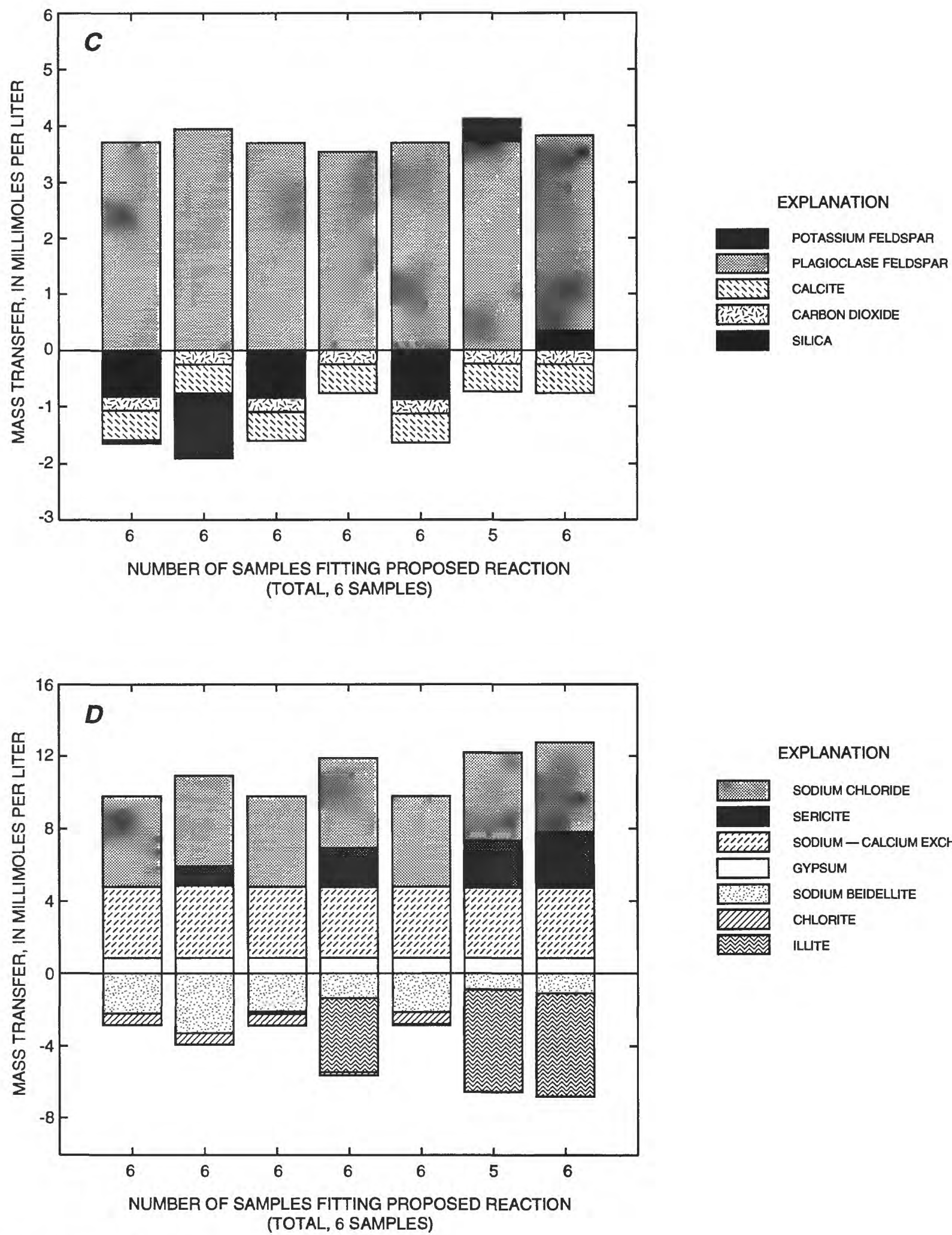

EXPLANATION

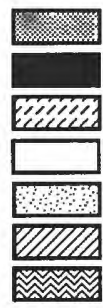

SODIUM CHLORIDE SERICITE

SODIUM - CALCIUM EXCHANGE GYPSUM

SODIUM BEIDELLITE CHLORITE ILLITE

Figure 20. Continued. 


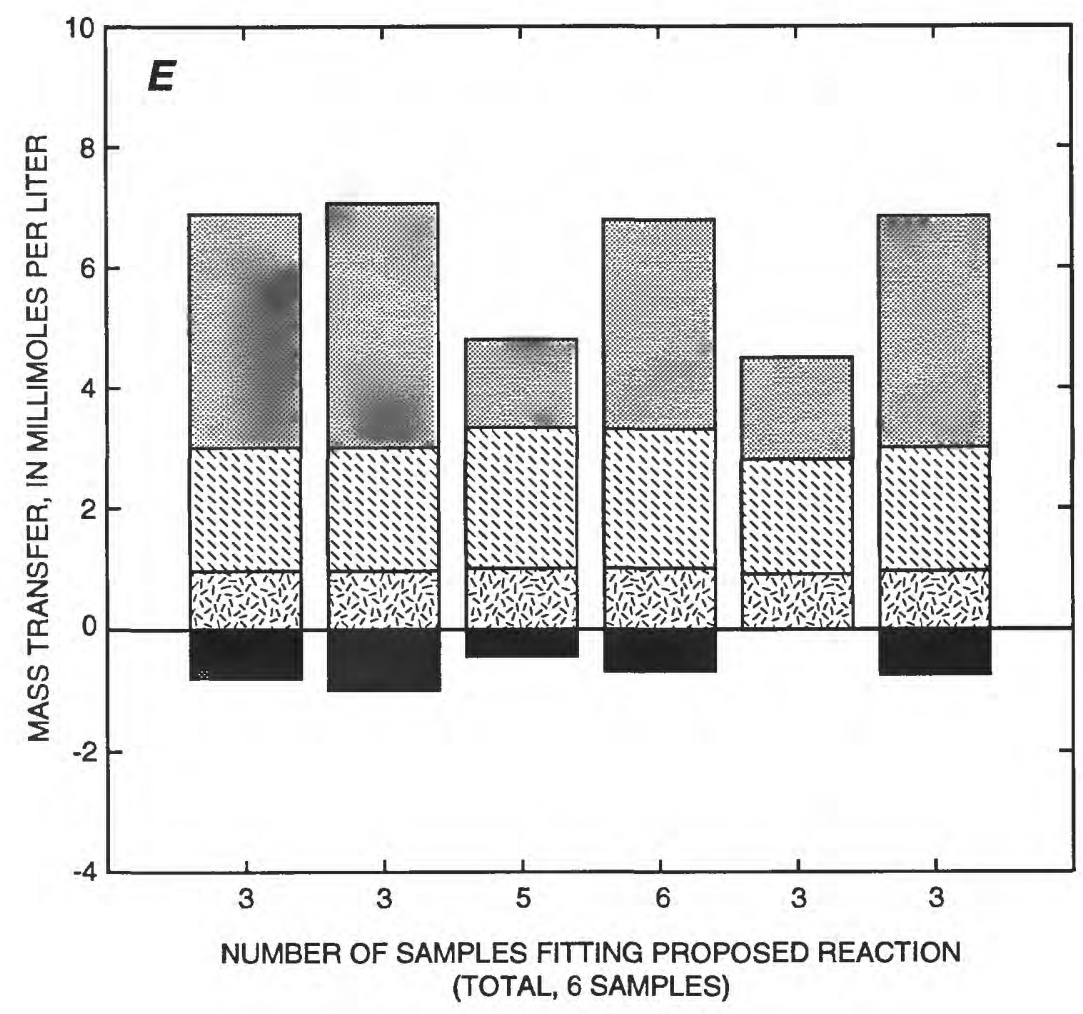

EXPLANATION

POTASSIUM FELDSPAR PLAGIOCLASE FELDSPAR CALCITE CARBON DIOXIDE SILICA

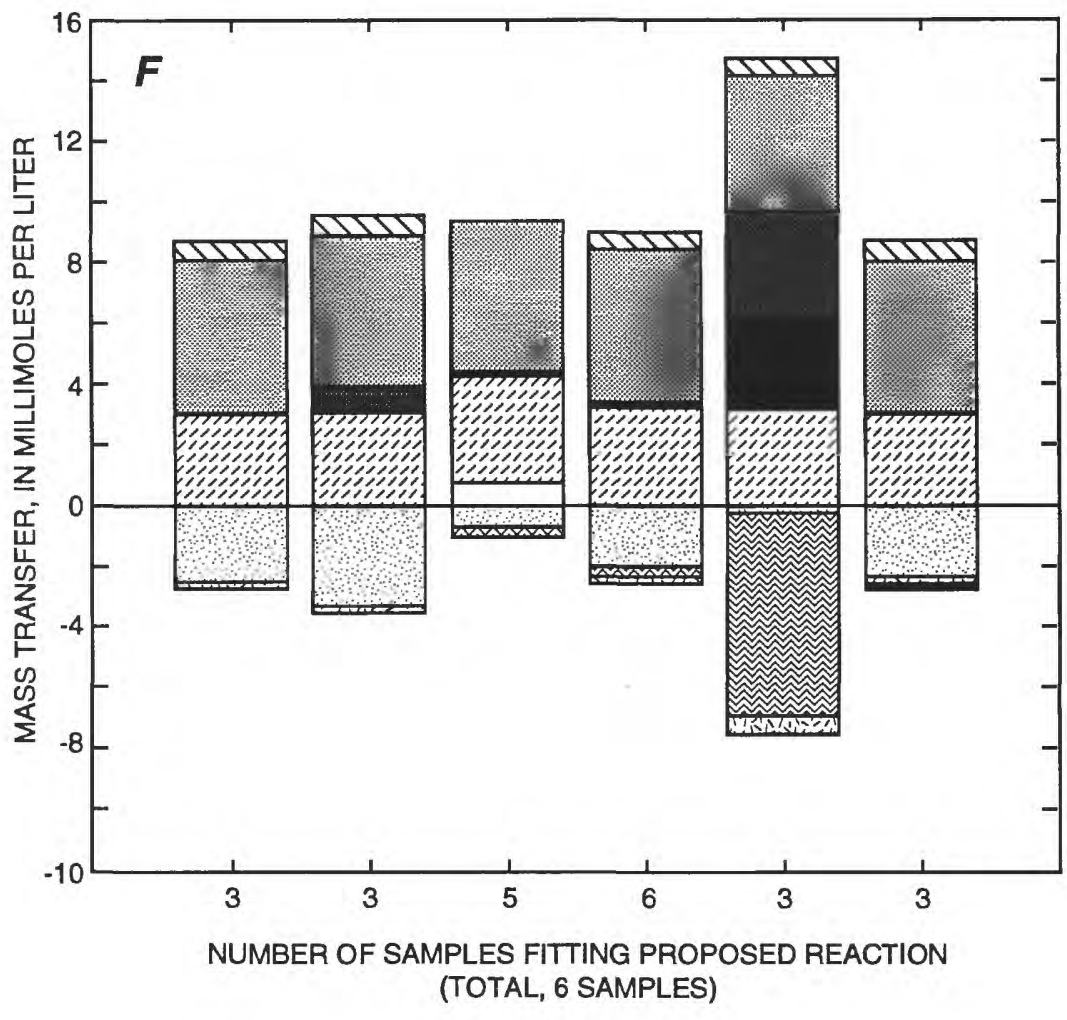

\section{EXPLANATION}

SODIUM CHLORIDE SERICITE SODIUM - CALCIUM EXCHANGE GYPSUM SODIUM BEIDELLITE PYRITE ILUTE AUGITE HEMATITE

Figure 20. Continued. 
Table 7. Saturation indices for selected minerals in ground-water sample as calculated by the computer program WATEQ4F (Ball and others, 1986)

[Symbol: --, data not calculated because aluminum concentration was not measured]

\begin{tabular}{|c|c|c|c|c|}
\hline \multirow[b]{2}{*}{$\begin{array}{c}\text { Phase } \\
\text { (composition) }\end{array}$} & \multicolumn{4}{|c|}{ Saturation Index ${ }^{1}$} \\
\hline & $\begin{array}{c}\text { Shallow } \\
\text { aquifers } \\
\text { near Falion } \\
\text { (site 142) }\end{array}$ & $\begin{array}{c}\text { Shallow } \\
\text { aqulfers } \\
\text { near } \\
\text { Stiliwater } \\
\text { (site 26) }\end{array}$ & $\begin{array}{c}\text { Intermediate } \\
\text { aquifers } \\
\text { near Fallon } \\
\text { (site 157) }\end{array}$ & $\begin{array}{c}\text { Basalt } \\
\text { aquifer } \\
\text { (site 111) }\end{array}$ \\
\hline Albite $\left(\mathrm{NaAlSi}_{3} \mathrm{O}_{8}\right)$ & -0.55 & 2.2 & -- & -- \\
\hline Anorthite $\left(\mathrm{CaAlSi}_{3} \mathrm{O}_{8}\right)$ & -3.4 & -2.4 & -. & -- \\
\hline Sodium beidellite $\left(\mathrm{Na}_{033} \mathrm{Al}_{233} \mathrm{Si}_{367} \mathrm{O}_{10}(\mathrm{OH})_{2}\right)$ & 3.5 & 5.5 & -- & -- \\
\hline Calcite $\left(\mathrm{CaCO}_{3}\right)$ & -.19 & .29 & -0.38 & 0.21 \\
\hline Chlorite $\left(\mathrm{Mg}_{5} \mathrm{Al}_{2} \mathrm{Si}_{3} \mathrm{O}_{10}(\mathrm{OH})_{8}\right)$ & -7.4 & -.76 & -- & -- \\
\hline Gypsum $\left(\mathrm{CaSO}_{4} \cdot 2 \mathrm{H}_{2} \mathrm{O}\right)$ & -2.1 & -.14 & -3.0 & -3.3 \\
\hline Halite $(\mathrm{NaCl})$ & -7.8 & -3.0 & -7.7 & -6.2 \\
\hline Hematite $\left(\mathrm{Fe}_{2} \mathrm{O}_{3}\right)$ & 14 & 14 & 17 & 15 \\
\hline Illite $\left(\mathrm{K}_{0.6} \mathrm{Mg}_{0.25} \mathrm{Al}_{2.3} \mathrm{Si}_{3.5} \mathrm{O}_{10}(\mathrm{OH})_{2}\right)$ & 2.3 & 5.0 & -- & -- \\
\hline Kaolinite $\left(\mathrm{Al}_{2} \mathrm{Si}_{2} \mathrm{O}_{5}(\mathrm{OH})_{2}\right)$ & 3.0 & 4.3 & -- & -- \\
\hline $\mathrm{K}$-mica (sericite) $\left(\mathrm{KAl}_{2}\left(\mathrm{AlSi}_{3} \mathrm{O}_{10}\right)(\mathrm{OH})_{2}\right)$ & 8.9 & 12 & -- & .- \\
\hline Rhodochrosite $\left(\mathrm{MnCO}_{3}\right)$ & -2.7 & -.085 & -.47 & -1.2 \\
\hline Siderite $\left(\mathrm{FeCO}_{3}\right)$ & -4.7 & -2.0 & -.90 & -8.2 \\
\hline Silica (amorphous) $\left(\mathrm{SiO}_{2}\right)$ & .023 & .14 & -.037 & -.34 \\
\hline
\end{tabular}

$$
{ }^{1} \text { Saturation Index (SI) is defined as: } \quad S I=\log \frac{I A P}{K e q} ;
$$

where

$I A P$ is the ion-activity product,

$K_{e q}$ is the equilibrium constant, and

$\log$ is the logarithm (base 10).

Saturation indices of near zero indicate the solution is in equilibrium with the mineral phase. Saturation indices less than zero indicate the solution is undersaturated and that the mineral, if present, may dissolve. Saturation indices greater than zero indicate the solution is supersaturated and the mineral can precipitate from the solution.

(1) The chemical activity ratios for Carson Desert ground water in the intermediate aquifers generally plot along slopes consistent with cation exchange reactions (figs. $21 A-C$ ). Specifically, a ratio of 2 will result where the aqueous geochemistry is controlled by the exchange of a divalent cation for a monovalent cation (Drever, 1982, p. 181-183) and corresponds to a slope of 2 on figures $21 A$ and $C$. Similarly, plots of two cations with the same valence will result in a slope of 1 on a diagram like figure $21 B$ if exchange controls the cation ratio. Most data for the intermediate aquifers have trends consistent with cation exchange being the geochemical control on the ratios of the major cations. In the shallow aquifers, calcium is being removed from solution at a rate greater than that attributed to simple cation exchange. Most likely, precipitation of calcite is limiting calcium concentrations in ground water within the shallow aquifers. 

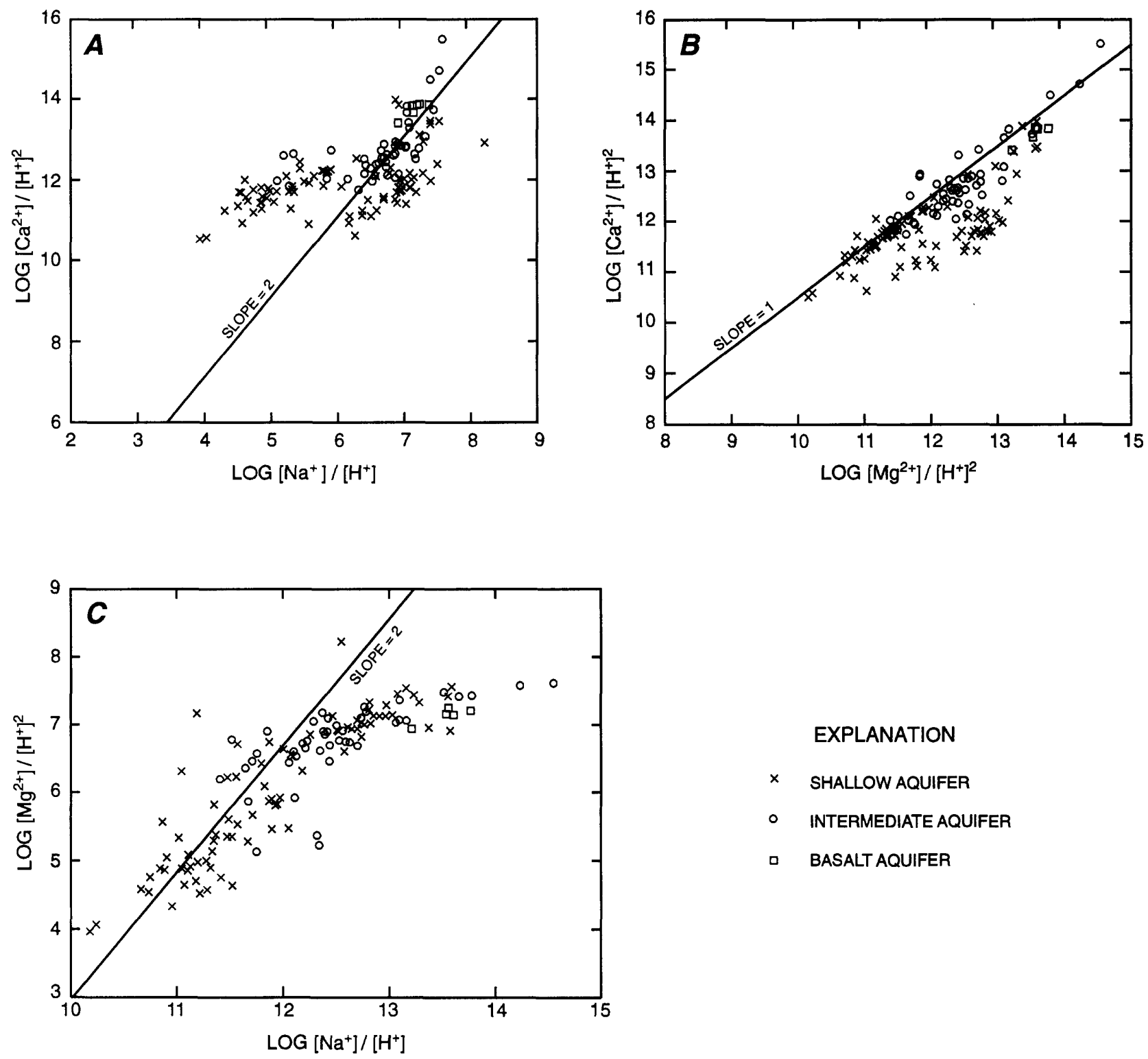

Figure 21. Relation between chemical activities of major constituents in ground water in the Carson Desert: $A$, calcium and sodium; $B$, calcium and magnesium; $C$, magnesium and sodium; $D$, sodium and silica; $E$, calcium and silica; $F$, magnesium and silica. All phase boundaries were calculated for a temperature of $25^{\circ}$ Celsius.

(2) The clay minerals kaolinite, beidellite (smectite), and chlorite are stable weathering products in most water samples from the basin-fill and basalt aquifers. Activity diagrams (figs. $21 D-F$ ) show the activities for ground-water samples on stability fields for minerals that commonly form in ground-water systems. Thermodynamic data for beidellite may not be valid in a strict thermodynamic sense (May and others, 1986). In contrast, studies of ground-water systems where beidellite is forming have shown that water appears to have stable ionic compositions that correspond to those indicated by solubility constants determined for beidellite (Drever, 1982, p. 177-190) and may be a result of a steady-state condition rather than true equilibrium. Although commonly adopted thermodynamic data for beidellite may not represent true equilibrium, the data are useful for the purpose of comparison with other systems where beidellite has been observed to be forming. 

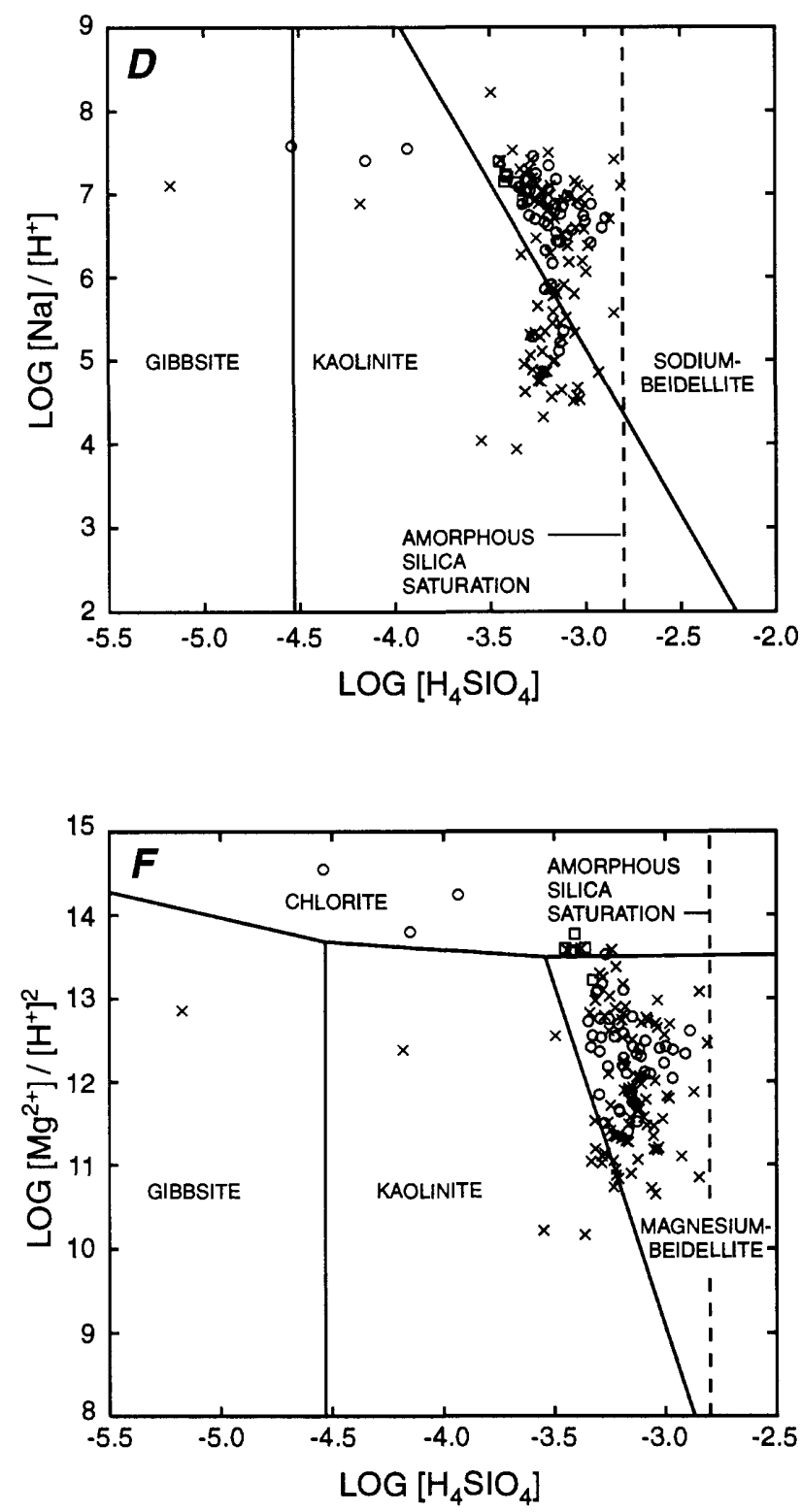

Figure 21. Continued.

Saturation indices, which are a measure of the thermodynamic state of a solution, have been calculated for calcite and amorphous silica. For the purposes of discussion, saturation indices of less than -0.5 are considered undersaturated, values ranging from -0.5 to 0.5 are considered to be saturated (at equilibrium), and values greater than 0.5 are oversaturated. Ground water in the aquifers of the Carson Desert is generally

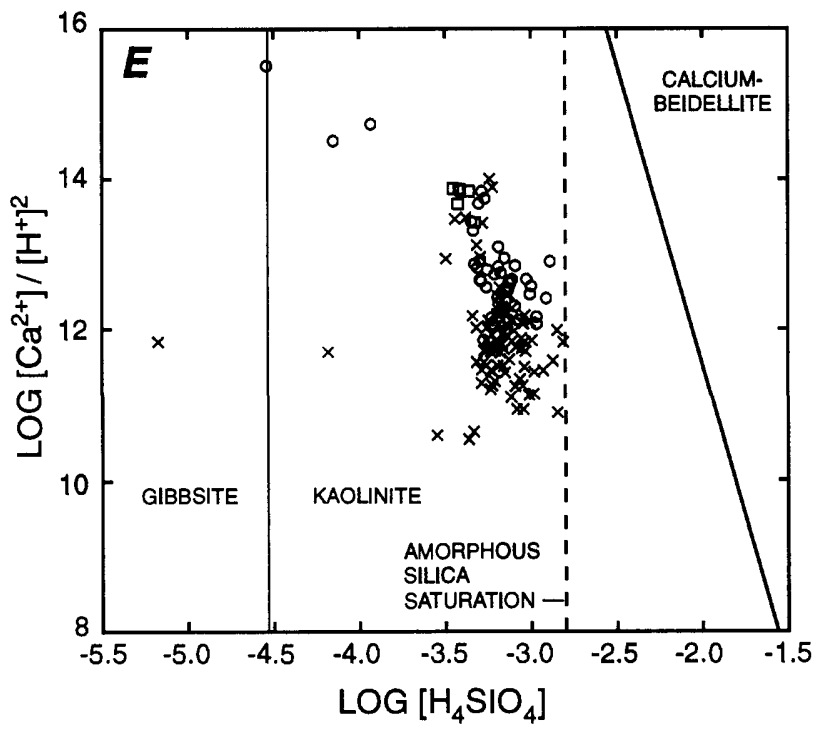

EXPLANATION

$\times \quad$ SHALLOW AQUIFER

- INTERMEDIATE AQUIFER

- BASALT AQUIFER at saturation with calcite (fig. 22A), which is consistent with dissolution or precipitation in the mass-balance models. The ground water is generally saturated (at equilibrium) with amorphous silica (fig. 22B), which also is consistent with the reactions that indicate precipitation or dissolution of small amounts of amorphous silica. 

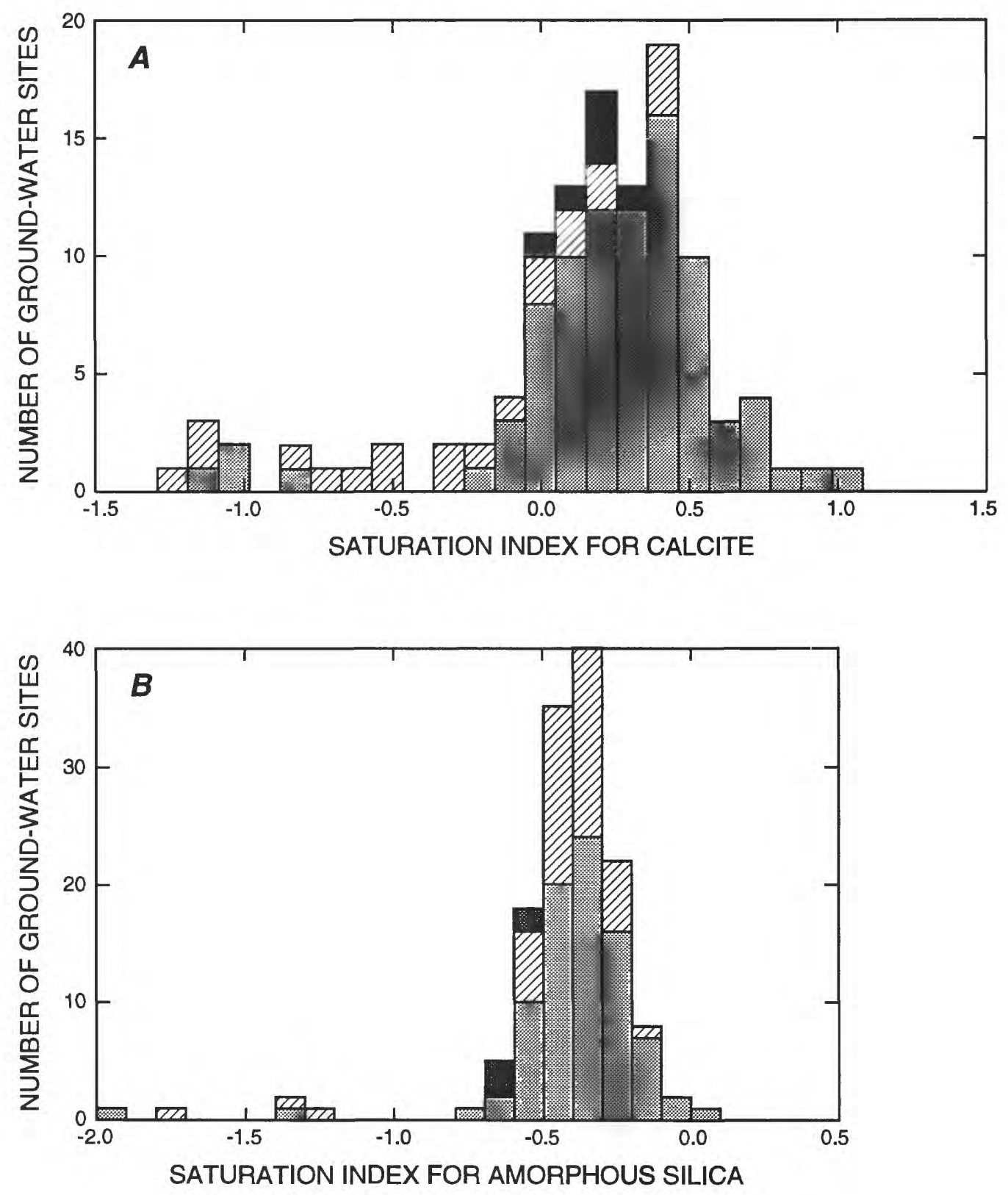

$B$, amorphous silica. 
The mass-balance model described above is consistent with (1) phases identified in the basin-fill and basalt deposits of Carson Desert; (2) chemical activity of major cations and silica; (3) saturation indices for calcite and amorphous silica; (4) phase relations for silicate minerals indicated by activity diagrams; and (5) mineralogic relations in shallow sediments, based on examination of thin sections. Although this approach does not yield a unique solution, it does yield a set of reactions that, taken together, provides a general reaction model for the major inorganic constituents.

\section{Minor Inorganic Constituents}

\section{Water Quality and Its Relation to Nevada State Drinking-Water Standards}

Minor constituents in ground water from the aquifers beneath the Carson Desert are of particular concern. Ground water used for drinking can have arsenic concentrations that exceed the MCL of $50 \mu \mathrm{g} / \mathrm{L}$ (fig. 23A). Boron concentrations commonly are greater than the recommended maximum value for long-term irrigation of sensitive crops $(750 \mu \mathrm{g} / \mathrm{L})$, which would not directly affect public health, but could reduce crop yields. Manganese concentrations commonly exceed the SMCL of $100 \mu \mathrm{g} / \mathrm{L}$ (fig. $23 B$ ), especially in the shallow aquifers. Representative analyses of concentrations of minor constituents of ground water from the Carson Desert are given in table 8.

Welch and others (1988) described the processes that control arsenic concentrations in ground water. The Carson Desert is similar to other areas in the western United States that contain high concentrations of arsenic in that (1) it contains basin-fill deposits of alluvial and lacustrine origins and is in a semiarid area region, (2) it contains volcanic deposits, and (3) it has thermal systems.

Concentrations of arsenic in the shallow, intermediate, and basalt aquifers are shown in figure 24. In general, median concentrations of arsenic are higher in the basalt aquifer than in the other aquifers. The greatest measured concentration of arsenic in the shallow aquifers is $1,100 \mu \mathrm{g} / \mathrm{L}$, the lowest measured concentration is less than $1 \mu \mathrm{g} / \mathrm{L}$, and the median concentration is $35 \mu \mathrm{g} / \mathrm{L}$. The greatest measured concentration in the intermediate aquifers was $1,400 \mu \mathrm{g} / \mathrm{L}$ and the lowest measured concentration was less than $1 \mu \mathrm{g} / \mathrm{L}$. The median arsenic concentration in the intermediate aquifers is $16 \mu \mathrm{g} / \mathrm{L}$. In the basalt aquifer, arsenic has a concentration range of 51 to $120 \mu \mathrm{g} / \mathrm{L}$ and a median concentration of $96 \mu \mathrm{g} / \mathrm{L}$ (fig. 23A). The areal distribution of arsenic is variable and concentrations can vary by an order of magnitude over short distances (fig. 24).

Concentrations of arsenic commonly exceed the MCL in all aquifers in the Carson Desert. The city of Fallon derives its public water supply from wells tapping the basalt aquifer that has arsenic concentrations in exceedance of the $50 \mu \mathrm{g} / \mathrm{L} \mathrm{MCL}$. Ground-water sites that have concentrations greater than the MCL for arsenic are shown in figure 17.

Boron is a component of igneous rocks and water in volcanic areas and many thermal springs typically contain high concentrations of boron (Hem, 1985). Boron is harmful to plants, and at very high concentrations is toxic to humans and wildlife. Concentrations of boron in the shallow aquifers range from 190 to $75,000 \mu \mathrm{g} / \mathrm{L}$ and have a median concentration of $1,600 \mu \mathrm{g} / \mathrm{L}$. In the shallow aquifers, boron concentrations are lowest in actively irrigated areas such as the Agricultural Research Station (inset $E$, fig. 25A) and highest in the unirrigated Soda Lakes-Upsal Hogback, Carson Pasture, and Stillwater Marsh areas (fig. 24A). Concentrations of boron in the intermediate aquifers range from 190 to $24,000 \mu \mathrm{g} / \mathrm{L}$ and the median concentration is $4,200 \mu \mathrm{g} / \mathrm{L}$. Concentrations of boron are lowest in the area nearest the city of Fallon and highest in the Soda Lakes-Upsal Hogback area. The median concentration of boron in the intermediate aquifers in the Fallon area $(920 \mu \mathrm{g} / \mathrm{L})$ is similar to the median concentration of boron in the Carson River and much less than the median concentration in the intermediate aquifers in the Soda Lakes-Upsal Hogback area. In both the shallow and intermediate aquifers, boron is a conservative element, meaning that as the dissolved-solids concentrations increase because of evaporative concentration, the boron concentrations increase concordantly. Boron and chloride (assumed to be a conservative element) are strongly correlated (Spearman's rho $=0.89$ ) with a linear relation indicating that boron also is acting conservatively during evaporative concentration (fig. 26). The same relation for boron and dissolved solids in surface water from the Stillwater area is described by Hoffman and others (1990) and Lico (1992). Water from the basalt aquifer has concentrations of boron that range from 490 to $2,200 \mu \mathrm{g} / \mathrm{L}$ and a has median concentration of $1,150 \mu \mathrm{g} / \mathrm{L}$. 


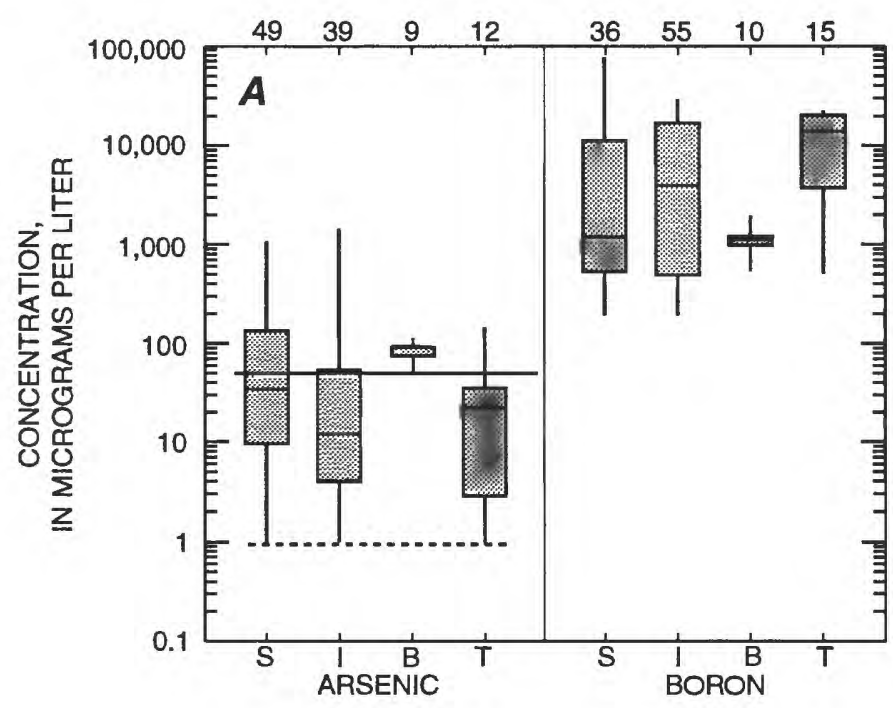

\section{EXPLANATION}

55 NUMBER OF ANALYSES

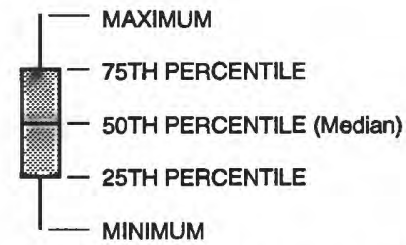

ANALYTICAL REPORTING LEVEL

PRIMARY OR SECONDARY MAXIMUM CONTAMINANT LEVEL

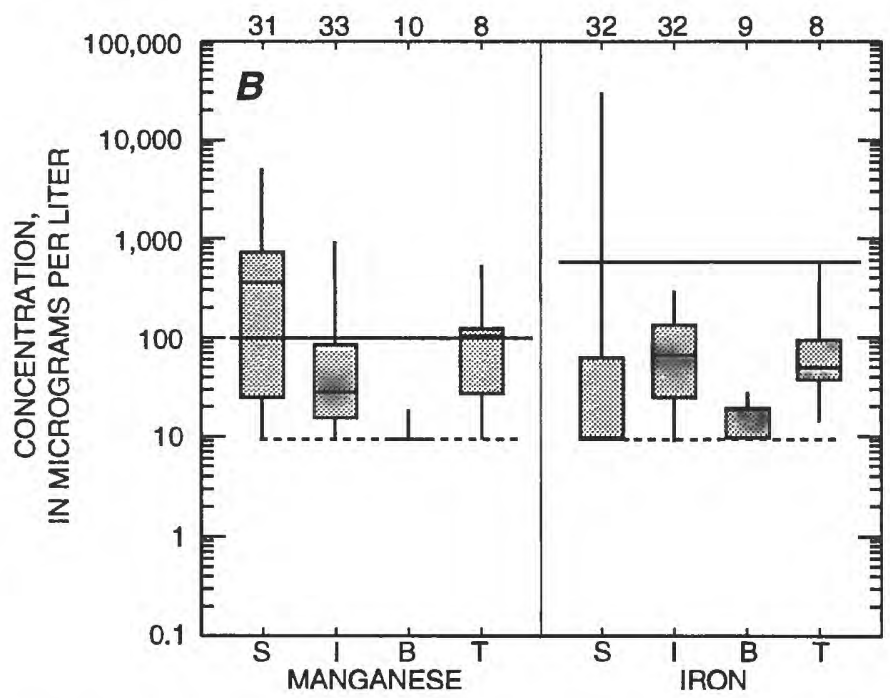

S SHALLOW AQUIFER

I INTERMEDIATE AQUIFER

B BASALT AQUIFER

T THERMAL AQUIFER

Figure 23. Concentrations of minor constituents in ground water in Carson Desert. A, arsenic and boron; $B$, manganese and iron.

Most other minor elements in the ground water of the Carson Desert are present at concentrations below federal and state standards. The shallow and thermal aquifers have the highest median and maximum concentrations of many of these elements, some of which do not have drinking-water MCL's (cobalt, lithium, molybdenum, nickel, rubidium, and vanadium). The highest median concentrations for barium, cadmium, chromium, cobalt, copper, lead, lithium, mercury, nickel, rubidium, and zinc are from wells in the thermal aquifers. The water from these aquifers is not used for human consumption, so the presence of these elements is not a indication of the quality of public supply in the Carson Desert. The shallow aquifers have the highest maximum concentrations for many minor elements, including manganese, iron, arsenic, boron, chromium, cobalt, copper, lead, lithium, molybdenum, nickel, selenium, and vanadium. Many of the shallow wells that have water with high concentrations of these elements are observation wells and are not used as sources of public supply. Iron concentrations in the shallow aquifers are highly variable and range from 1.4 to $31,000 \mu \mathrm{g} / \mathrm{L}$. Likewise, manganese concentrations have a large range of values, from less than 1 to $5,400 \mu \mathrm{g} / \mathrm{L}$. The distribution of highly variable concentrations is similar to that found for arsenic in this study and reported by Glancy (1986) and Lico and others (1987). 


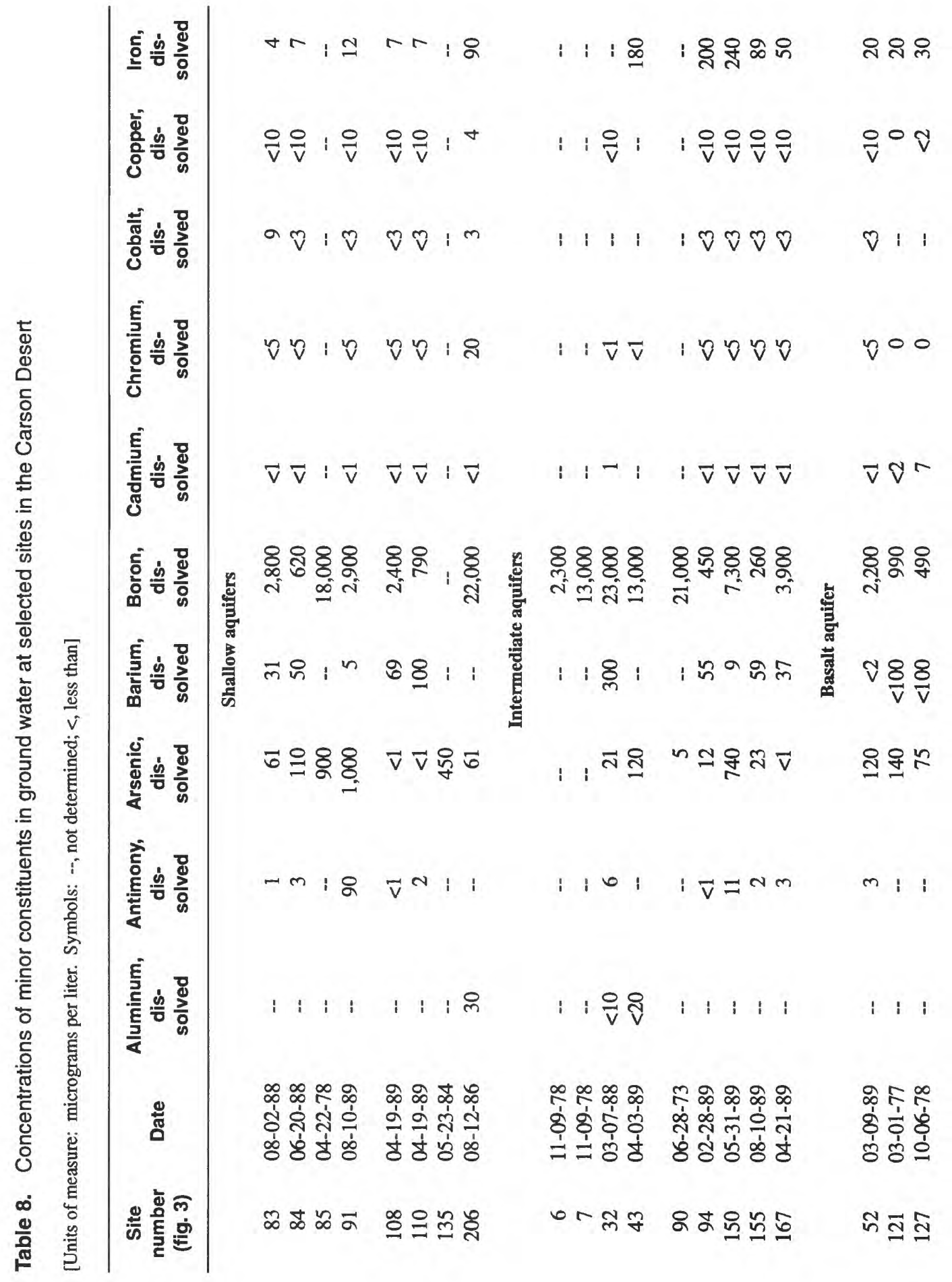




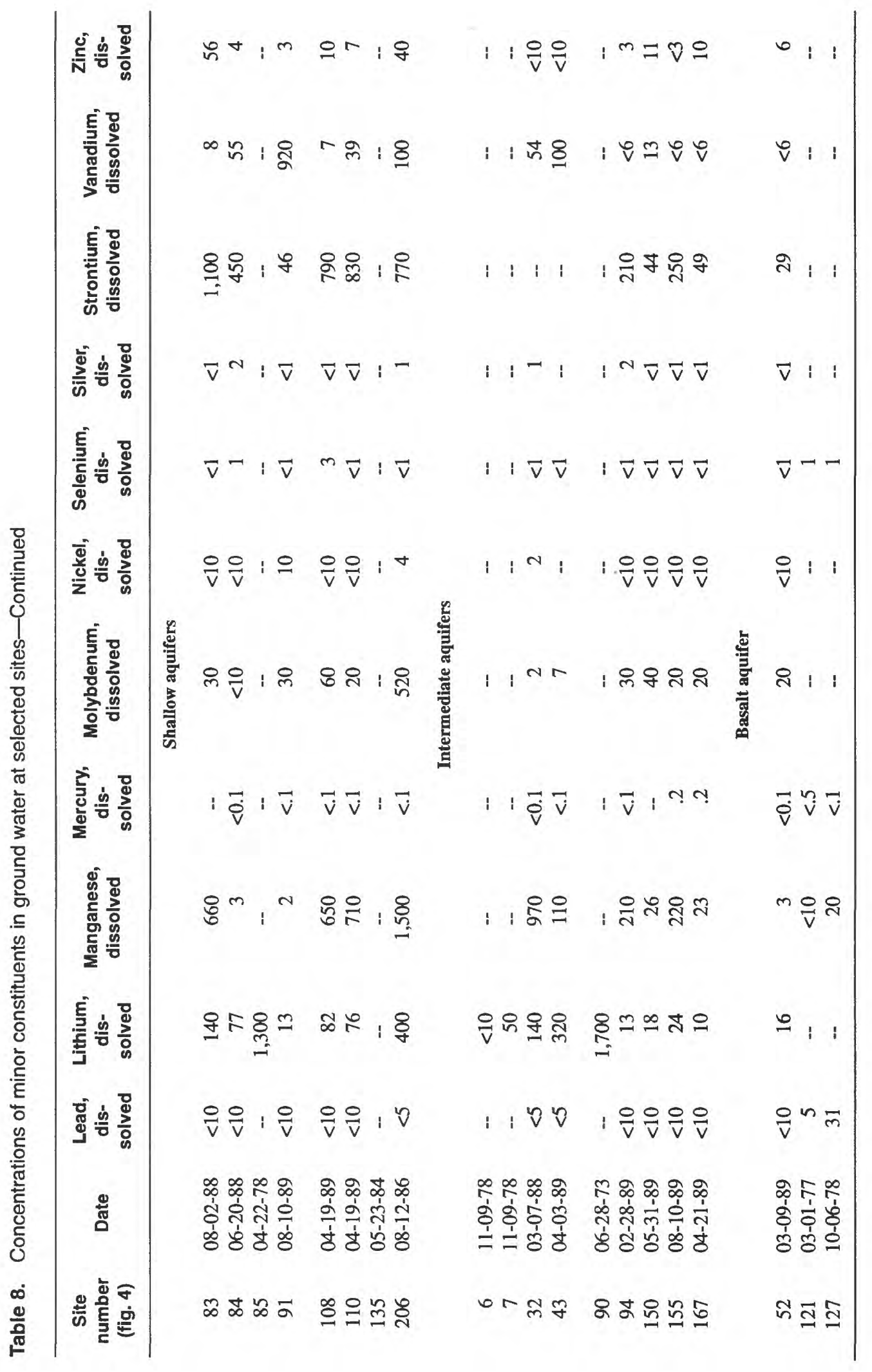




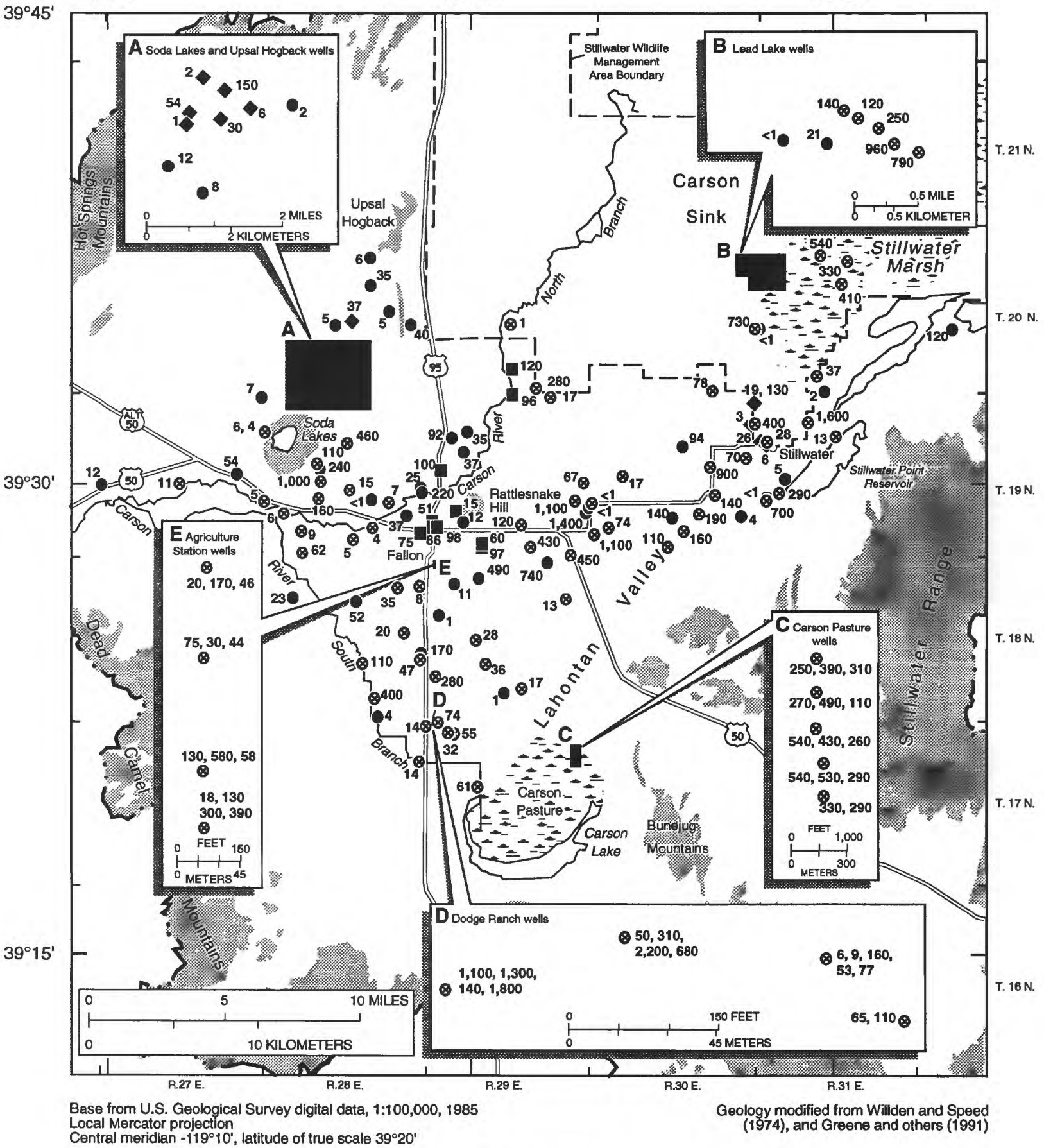

EXPLANATION
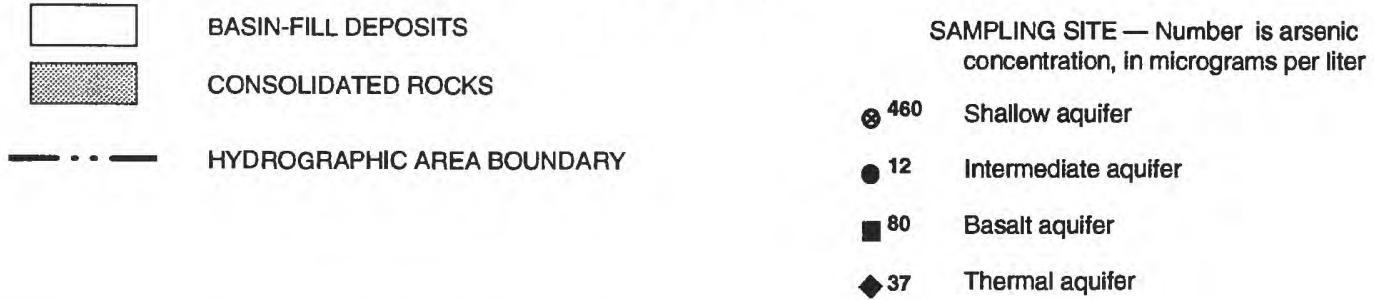

Figure 24. Concentrations of dissolved arsenic in ground water. 


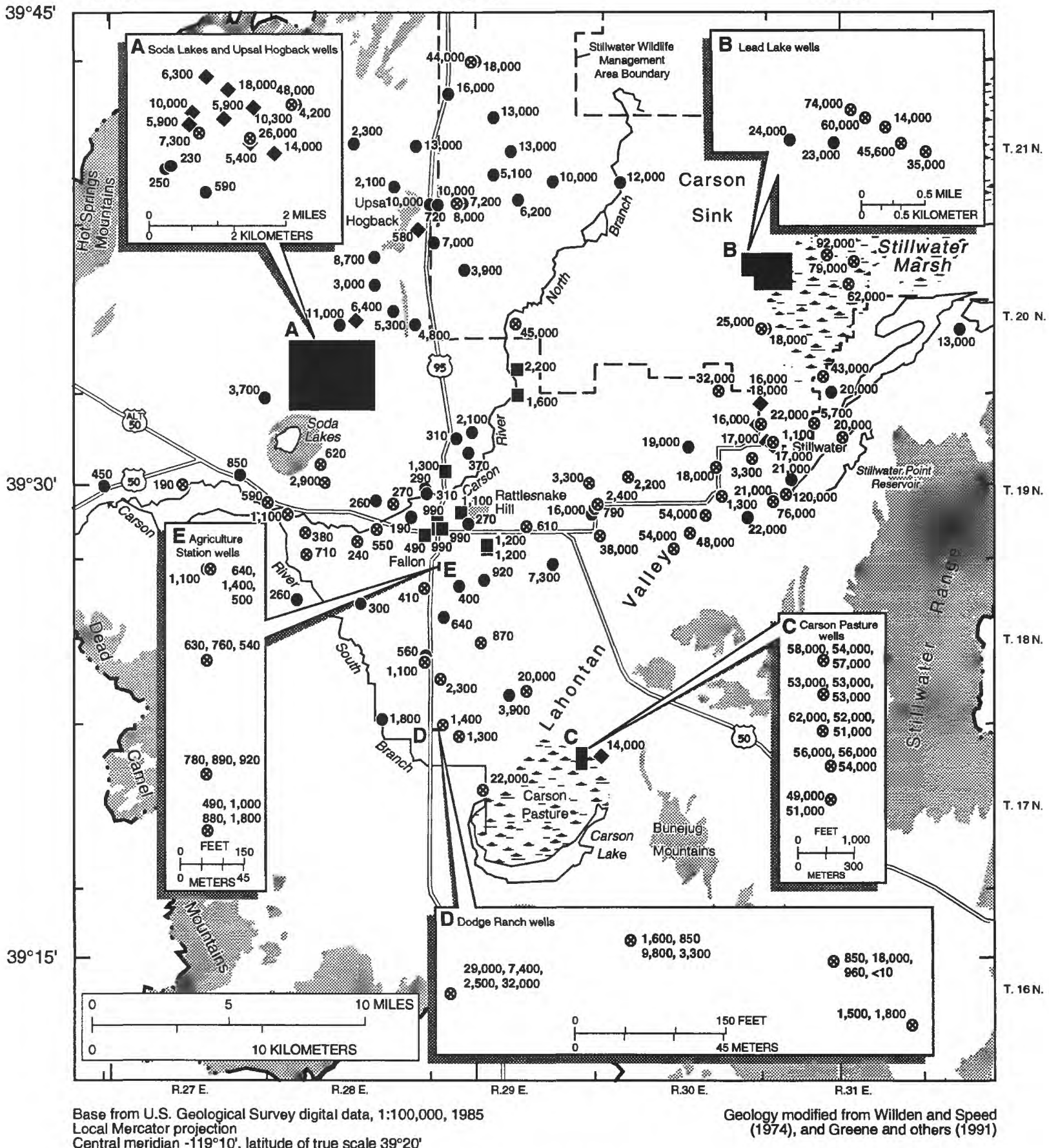

Central meridian $-119^{\circ} 10^{\prime}$, latitude of true scale $39^{\circ} 20^{\prime}$

\section{EXPLANATION}
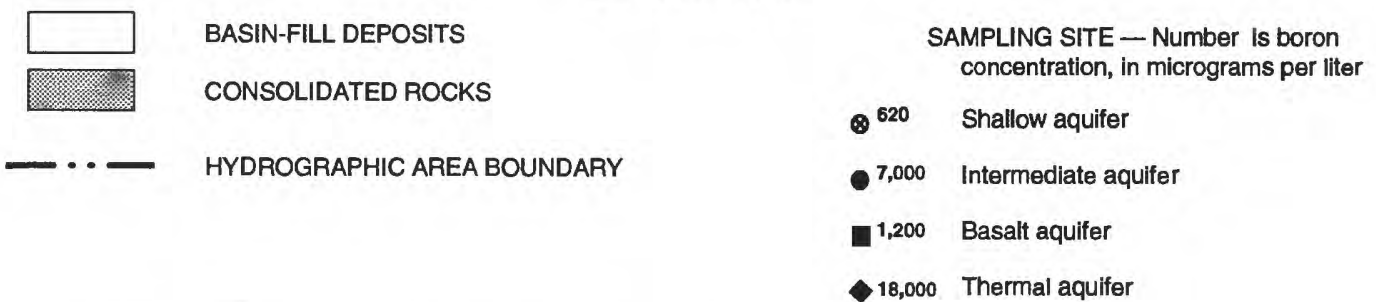

Figure 25. Concentrations of dissolved boron in ground water. 


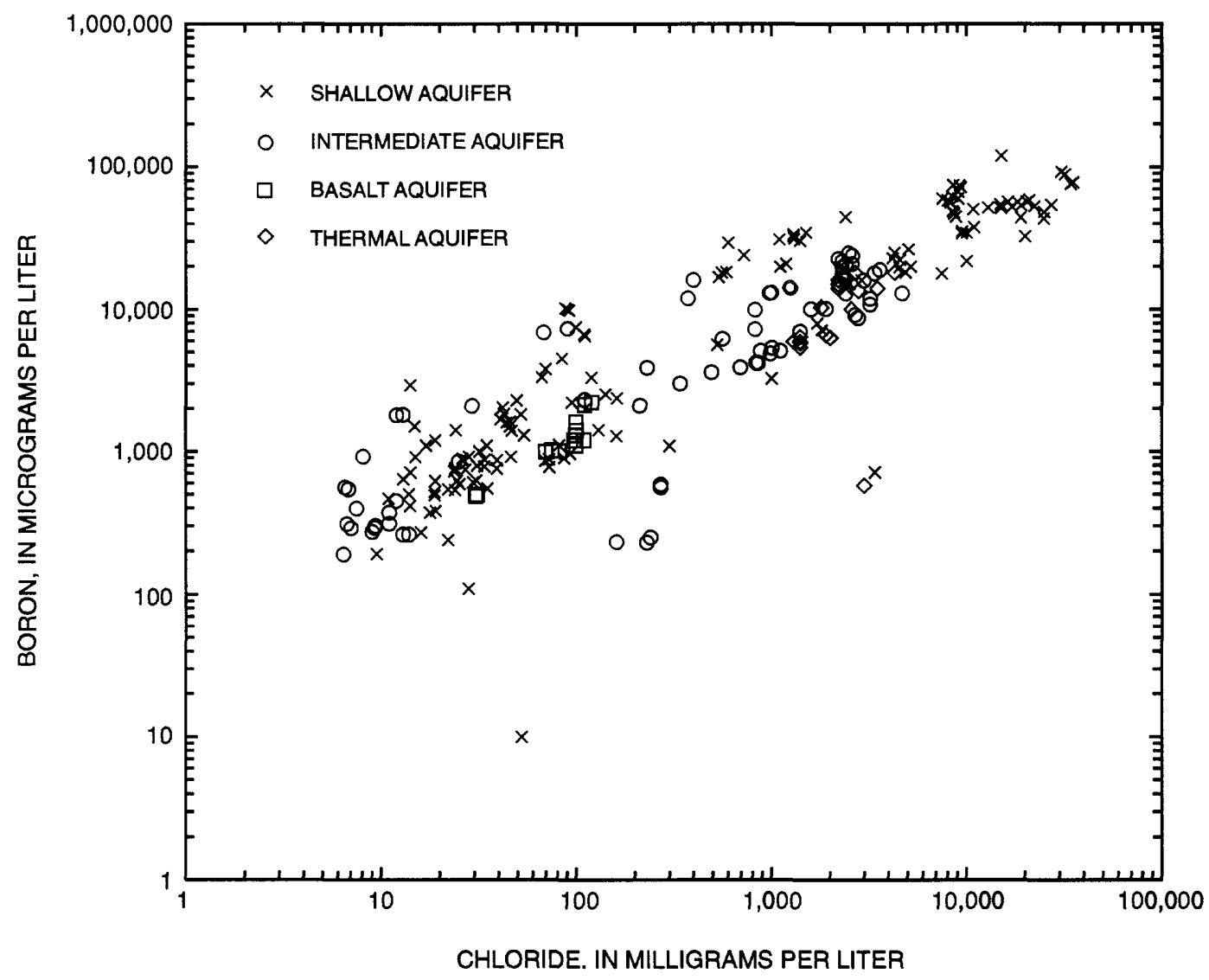

Figure 26. Relation between boron and chloride concentrations in ground water in the Carson Desert.

Only a few ground-water sites sampled in the Carson Desert have water that exceeds MCL's for minor elements other than arsenic (fig. 17). Cadmium is greater than or equal to $5 \mu \mathrm{g} / \mathrm{L}$ in five samples. Selenium exceeds the MCL of $50 \mu \mathrm{g} / \mathrm{L}$ in five wells.

The only minor elements that exceed SMCL's are manganese and iron. A total of 40 sites from the shallow and intermediate aquifers have ground water with manganese concentrations greater than $0.1 \mathrm{mg} / \mathrm{L}$. Seven samples have concentrations of iron that are greater than the SMCL. The sites that have ground water in exceedance of the SMCL for iron and manganese are shown in figure 15.

\section{Processes Affecting Concentrations of Minor Constituents}

Arsenic concentrations are highly variable and probably controlled by local redox conditions in the aquifers. Lico (1992) has described the processes responsible for the mobilization of arsenic in the shallow aquifers near Stillwater Wildlife Management
Area. Dissolution of volcanic-rock fragments and iron oxyhydroxides possibly releases arsenic to the ground water. Lico and others (1986) noted that concentrations of arsenic in volcanic rock fragments and iron oxyhydroxide-coated grains are substantially greater than those in other grain types (quartz and feldspar). Discrete arsenic-bearing mineral phases have not been identified in the basin-fill aquifers of the Carson Desert; however, the methods used to identify the mineralogic composition of the sediments probably are not sensitive enough to detect small amounts of a specific mineral. Processes that control the concentrations of arsenic in the Carson Desert are discussed in more detail by Welch and others (1988), Welch and Lico (1988), and A.H. Welch (U.S. Geological Survey, written commun.,1991).

Concentrations of iron and manganese are weakly correlated (Spearman's rho $=0.36$ ) with the higher manganese concentrations tending to have higher iron concentrations (fig. 27). Iron and manganese concentrations in water samples from the intermediate basin-fill and basalt aquifers are slightly 
better correlated with a Spearman's rho of 0.45 . Iron and manganese concentrations tend to have no relation (Spearman's rho $=0.008$ and -0.014 , respectively) to dissolved oxygen concentrations (figs. $26 B$ and $C$ ). The sampling procedures used for ground-water samples may introduce air into the sample prior to the measurement of dissolved oxygen, thus the actual concentrations of dissolved oxygen may be less than those reported here. Iron concentrations are weakly correlated (Spearman's rho $=0.38$ ) and manganese concentrations are moderately correlated (Spearman's rho $=0.54$ ) with dissolved organic carbon concentrations (figs. $27 D$ and $E$ ). Only some samples with dissolved organic carbon greater than $20 \mathrm{mg} / \mathrm{L}$ have iron and manganese concentrations greater than $10 \mu \mathrm{g} / \mathrm{L}$.

These relations suggest that dissolved oxygen is being depleted by reaction with organic carbon. An abundant source of sedimentary organic matter must be present in parts of the shallow aquifers because all of the samples with high dissolved organic carbon (greater than $10 \mathrm{mg} / \mathrm{L}$ ), except one, are from the shallow aquifers. Therefore, organic carbon is not a limiting factor in the removal of dissolved oxygen from the shallow ground water. For water within the intermediate basin-fill aquifers where all dissolved oxygen has been depleted, organic-carbon concentrations are less than or equal to $1 \mathrm{mg} / \mathrm{L}$ in all but one sample. Once the dissolved oxygen is gone, dissolved organic carbon can react with iron and manganese oxides, if they are present on the aquifer material, producing relatively high concentrations of these two metals in ground water.

The reaction of dissolved organic carbon with iron and manganese oxides is consistent with the hydrogeologic regimes in the shallow aquifers of the Carson Desert, that contain most of the water with high concentrations of iron and manganese. The sediment in the shallow aquifers primarily consists of alluvial and lacustrine deposits, which, in general, have oxide coatings (Jenne, 1968). Prior to the construction of the Newlands Project, which brought large-scale irrigation to the Carson Desert, the water table was below present levels, by as much as $60 \mathrm{ft}$ in places (Rush, 1972). This rise in the water table has saturated sediment that was previously unsaturated, thus changing the geochemical environment of the sediment. This has resulted in the dissolution of sedimentary organic matter that reacted with the dissolved oxygen and oxide coatings on the aquifer material. Thus, the changes brought on by large-scale irrigation in the Carson Desert may be directly responsible for water with high concentrations of iron and manganese (arsenic and uranium) in parts of the area.

Ground water with high concentrations of iron and manganese in the Carson Desert generally approaches equilibrium with respect to the carbonate minerals siderite and rhodochrosite at high concentrations of iron and manganese (fig. 28A and $B$ ). These minerals have not been identified in the basin-fill aquifers in the Carson Desert, but are known to form in anoxic nonmarine water. Siderite has been identified as a secondary mineral precipitating from oxygendepleted ground water in Oregon (Magaritz and Luzier, 1985) and rhodochrosite has been reported from several localities (Jones and Bowser, 1978, p. 215-219). These carbonate minerals possibly are one of the limiting factors controlling the concentrations of iron and manganese in the ground water.

\section{Radionuclides}

\section{Water Quailty and its Reiation to Nevada State Drinking-Water Standards}

Radionuclides of concern in ground water of the Carson Desert include uranium and radon. Gross measurements of ground-water radioactivity, such as gross-alpha and gross-beta activities, commonly are used as screening methods for the presence of radionuclides in public-water supplies (U.S. Environmental Protection Agency, 1986a and b). These gross measurements provide an estimate of the total contribution of alpha or beta emitters in the sample, except for gases, such as radon. Maximum contaminant levels (MCL's) have been proposed for most commonly occurring radionuclides (U.S. Environmental Protection Agency, 1991). The MCL's are uranium, $20 \mu \mathrm{g} / \mathrm{L}$; adjusted gross-alpha activity, $15 \mathrm{pCi} / \mathrm{L}$; radium- 226 , $20 \mathrm{pCi} / \mathrm{L}$; radium-228, $20 \mathrm{pCi} / \mathrm{L}$; and radon-222, $300 \mathrm{pCi} / \mathrm{L}$. Concentrations of radio-nuclides in representative ground-water samples from the Carson Desert are shown in table 9.

The minimum uranium concentration in the shallow aquifers is $1.1 \mathrm{pCi} / \mathrm{L}$, the greatest is $305 \mathrm{pCi} / \mathrm{L}$, and the median is $29 \mathrm{pCi} / \mathrm{L}$ (fig. 29). The highest concentrations are found in shallow ground water from the Carson Pasture area. Ground water from the Stillwater Marsh area also has high uranium concentrations (Lico, 1992). Both Carson Pasture and Stillwater Marsh are discharge areas where solutes are highly concentrated by evaporation. Most of the wells sampled in these areas are observation wells and are not used as sources of drinking water. The highest concentration measured 
in a well used as a drinking-water source was $54 \mathrm{pCi} / \mathrm{L}$. The intermediate aquifers had a range of uranium concentrations from less than 0.2 to $31 \mathrm{pCi} / \mathrm{L}$ and a median of $0.5 \mathrm{pCi} / \mathrm{L}$. In the basalt aquifer, uranium concentrations range from less than $0.3 \mathrm{pCi} / \mathrm{L}$ to $2.2 \mathrm{pCi} / \mathrm{L}$ and have a median of $1.5 \mathrm{pCi} / \mathrm{L}$. The only sample analysis from the thermal aquifer has a uranium concentration of less than $0.4 \mu \mathrm{g} / \mathrm{L}$.

Gross-alpha activities in samples from the shallow aquifers range from 0.27 to $290 \mathrm{pCi} / \mathrm{L}$ and have a median activity of $24 \mathrm{pCi} / \mathrm{L}$. In the intermediate aquifers, the minimum, maximum, and median grossalpha concentrations are $0.27,52$, and $3.7 \mathrm{pCi} / \mathrm{L}$ as natural uranium, respectively. Gross-alpha activity in water from the basalt aquifer ranges from a minimum of $1.6 \mathrm{pCi} / \mathrm{L}$ to a maximum value of $4.2 \mathrm{pCi} / \mathrm{L}$ and the median is $2.0 \mathrm{pCi} / \mathrm{L}$. One sample was analyzed from the thermal aquifers and it has a gross-alpha radioactivity of less than $0.27 \mathrm{pCi} / \mathrm{L}$.

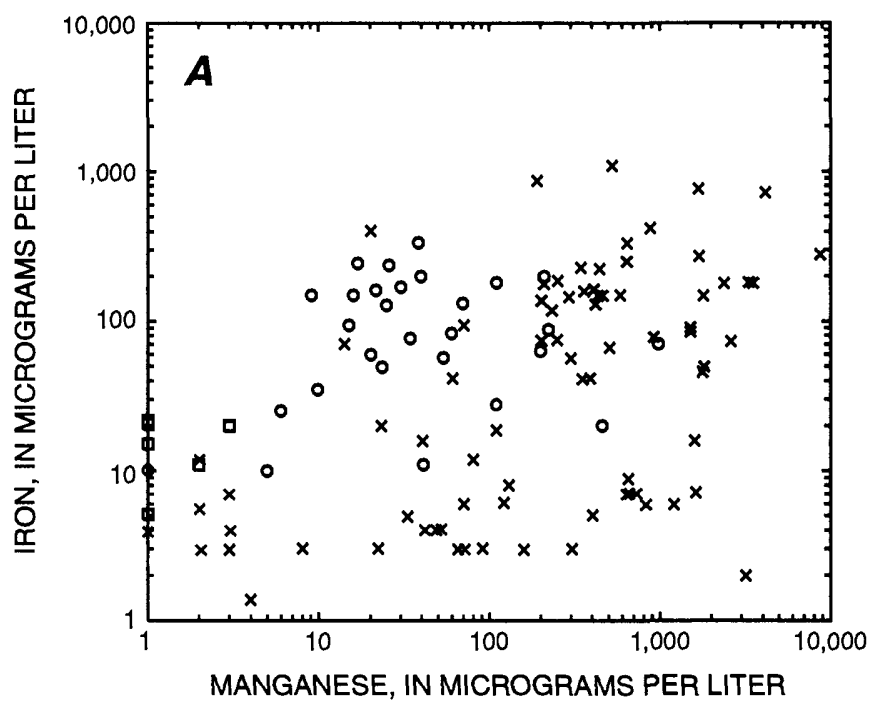

EXPLANATION

$\times$ SHALLOW AQUIFER

- INTERMEDIATE AQUIFER

- BASALTAQUIFER
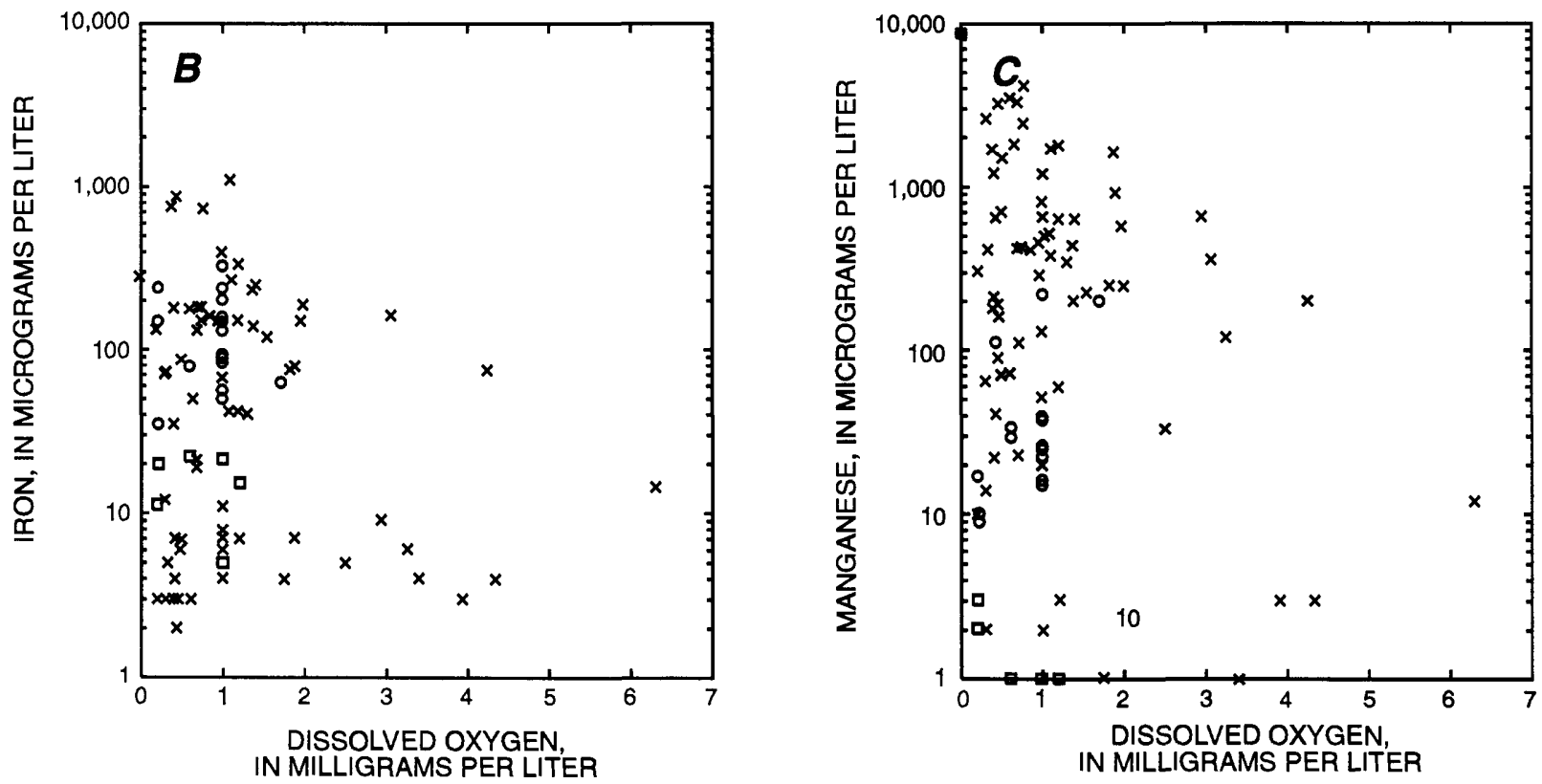

Figure 27. Relations between dissolved constituents in ground water in the Carson Desert. $A$, iron and manganese; $B$, iron and oxygen; $C$, manganese and oxygen; $D$, organic carbon and iron; $E$, organic carbon and manganese. 
Essentially all of the observed gross-alpha activity in ground water from the Carson Desert can be explained as that contributed by dissolved uranium. Uranium concentration compared with gross-alpha concentration is plotted in figure 30 and shows the relation between these two parameters. The data plot along lines that correspond to uranium activity ratios from 1.0 to 1.4 , common values for ground water in the Carson River Basin (Thomas and others, 1993). At lower uranium concentrations, the data points tend to deviate from the activity ratio lines (mostly higher gross-alpha activity) than that at higher uranium concentrations indicating another source of gross-alpha radioactivity. The analytical uncertainty also is greater at low uranium concentrations. A possible source for this excess gross-alpha activity is polonium-210 (Thomas and others, 1993).

In the shallow aquifers, the lowest concentration of radium-226 is $0.04 \mathrm{pCi} / \mathrm{L}$, the highest is $0.77 \mathrm{pCi} / \mathrm{L}$, and the median is $0.14 \mathrm{pCi} / \mathrm{L}$ (fig. 29). The highest concentration of radium-226 in the intermediate aquifers $0.16 \mathrm{pCi} / \mathrm{L}$, the lowest is less than $0.02 \mathrm{pCi} / \mathrm{L}$, and the median is $0.05 \mathrm{pCi} / \mathrm{L}$. One sample was collected from the thermal aquifers and it has a radium-226 concentration of $1.5 \mathrm{pCi} / \mathrm{L}$. No samples were analyzed for radium-226 from the basalt aquifer.

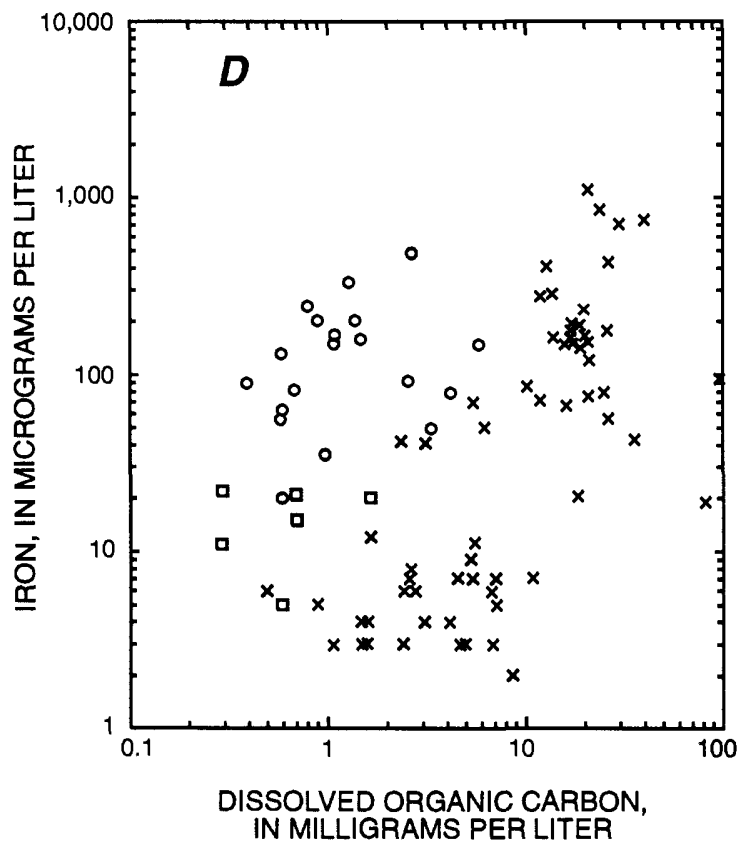

Figure 27. Continued.
Gross-beta activities in the shallow aquifers range from 5.8 to $1,200 \mathrm{pCi} / \mathrm{L}$ and have a median of $35 \mathrm{pCi} / \mathrm{L}$ (fig. 29). Ground water from the intermediate aquifers has a minimum gross-beta activity of $2.7 \mathrm{pCi} / \mathrm{L}$, a maximum of $64 \mathrm{pCi} / \mathrm{L}$, and a median of $12 \mathrm{pCi} / \mathrm{L}$. The minimum gross-beta activity in the basalt aquifer is $11 \mathrm{pCi} / \mathrm{L}$, the maximum is $24 \mathrm{pCi} / \mathrm{L}$, and the median is $12 \mathrm{pCi} / \mathrm{L}$. There is one analysis from the thermal aquifers for gross-beta activity and it has a value of $180 \mathrm{pCi} / \mathrm{L}$. The two main sources of grossbeta activity are potassium- 40 and uranium. Figure 31 shows the relation between gross-beta (corrected for the contribution from potassium-40) and uranium activities. As with the gross-alpha activity, gross-beta activity is closely related to uranium concentration. At lower uranium concentrations, the relation becomes rather poor and indicates another source of gross-beta activity as well as greater analytical uncertainty. Two possible sources are identified by Thomas and others (1993) that may cause the deviation from this relation at low gross-beta activities. Ingrowth of thorium-234 has been found to occur in samples between collection and analysis and lead-210 may be a significant grossbeta contributor in samples with low gross-beta activities.

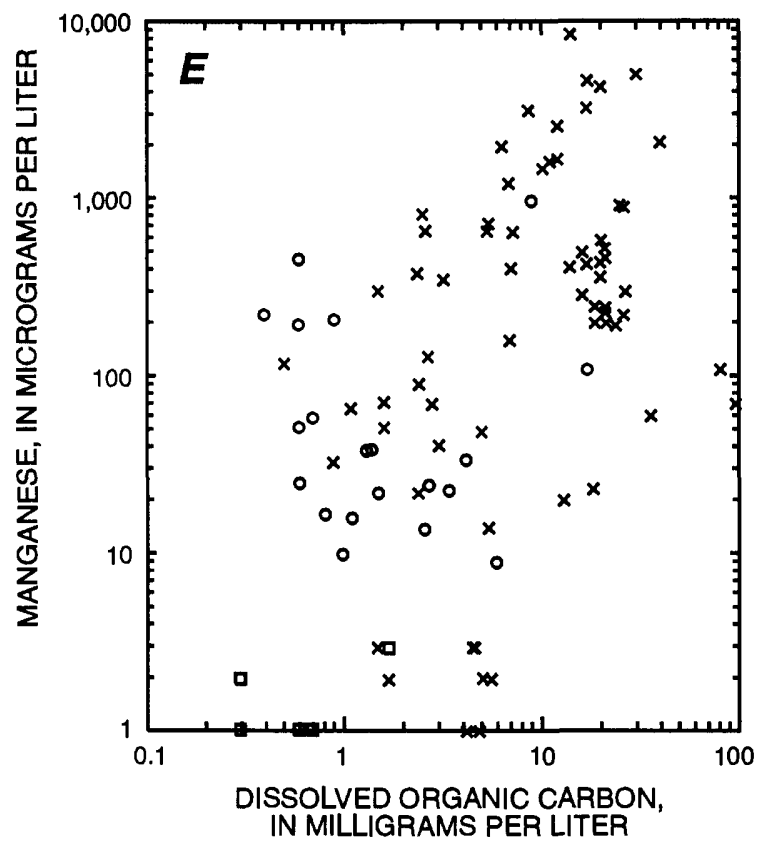




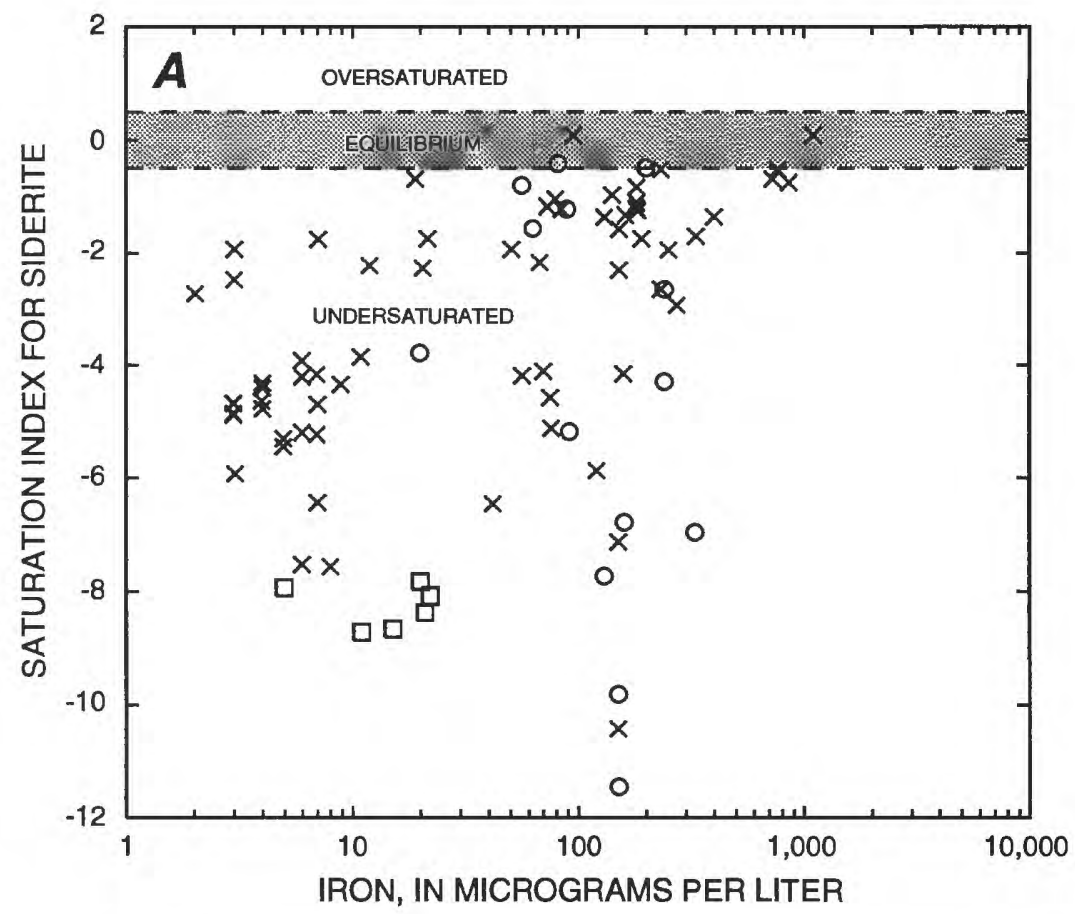

\section{EXPLANATION \\ $\times$ SHALLOW AQUiFER \\ - INTERMEDIATE AQUIFER \\ 口 BASALT AQUIFER}

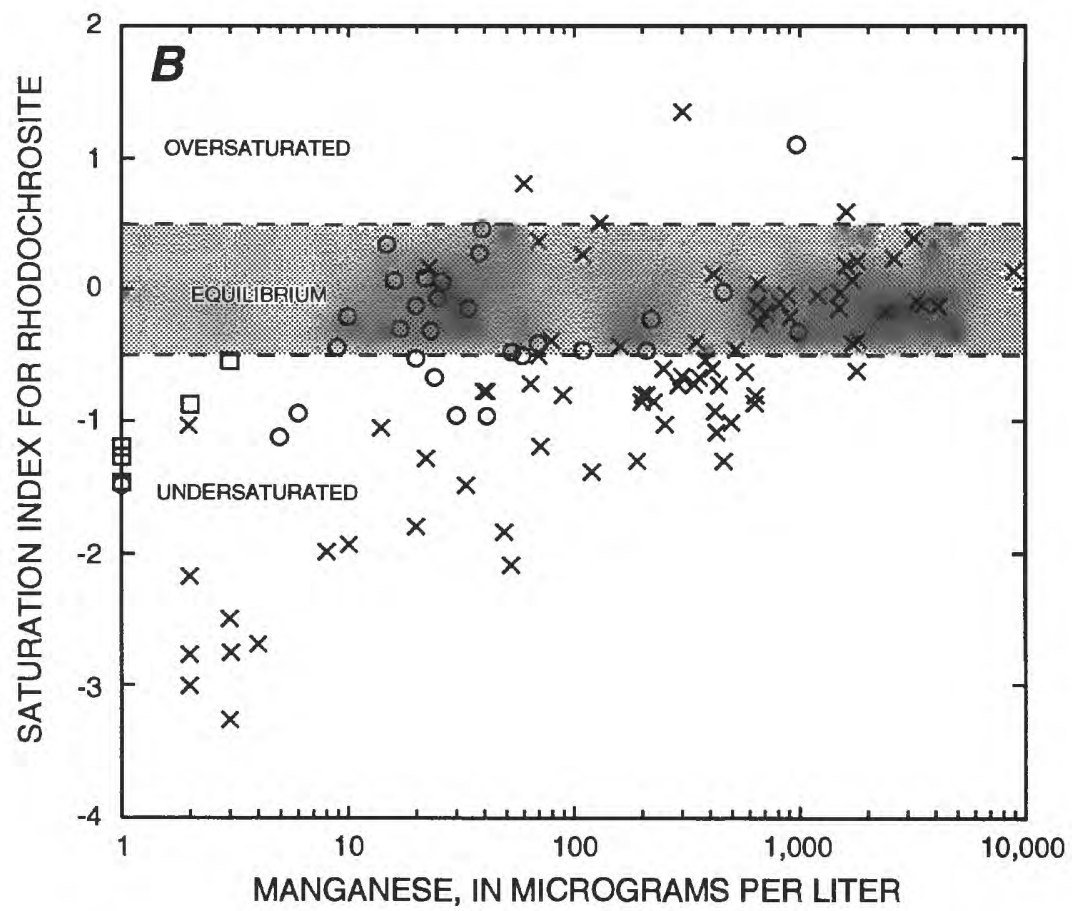

Figure 28. Relation between $A$, dissolved iron and saturation index for siderite; and $B$, dissolved manganese and saturation index for rhodochrosite in ground water in the Carson Desert. 


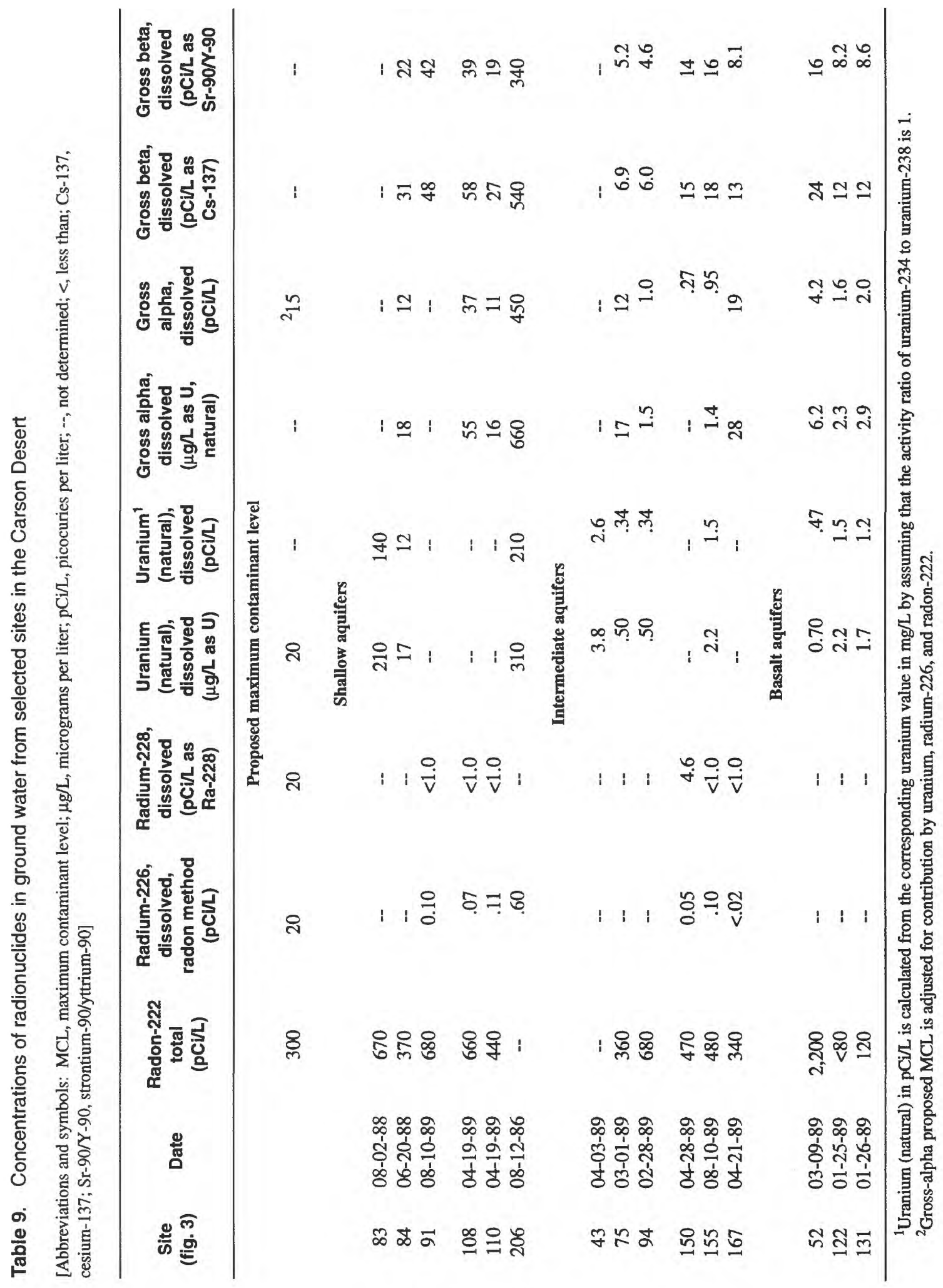


Water samples from the shallow aquifers have radium-228 concentrations that range from the detection limit (less than 1.0) to $2.8 \mathrm{pCi} / \mathrm{L}$ and have a median concentration of less than $1.0 \mathrm{pCi} / \mathrm{L}$ (fig. 29). Radium228 concentrations in the intermediate aquifers range from less than 1.0 to $4.6 \mathrm{pCi} / \mathrm{L}$ and have a median concentration of less than $1.0 \mathrm{pCi} / \mathrm{L}$. No samples were analyzed from the basalt and thermal aquifers for radium-228.
The statistical distribution of radon concentrations in the Carson Desert ground-water system is shown in figure $29 B$. The radon- 222 concentration in the shallow aquifers ranges from 180 to $1,300 \mathrm{pCi} / \mathrm{L}$ and the median concentration is $650 \mathrm{pCi} / \mathrm{L}$. The radon222 concentration in the intermediate aquifers in the Fallon area ranges from less than 80 to $760 \mathrm{pCi} / \mathrm{L}$ and the median concentration is $470 \mathrm{pCi} / \mathrm{L}$. Radon data are not available for the Soda Lakes-Upsal Hogback area.

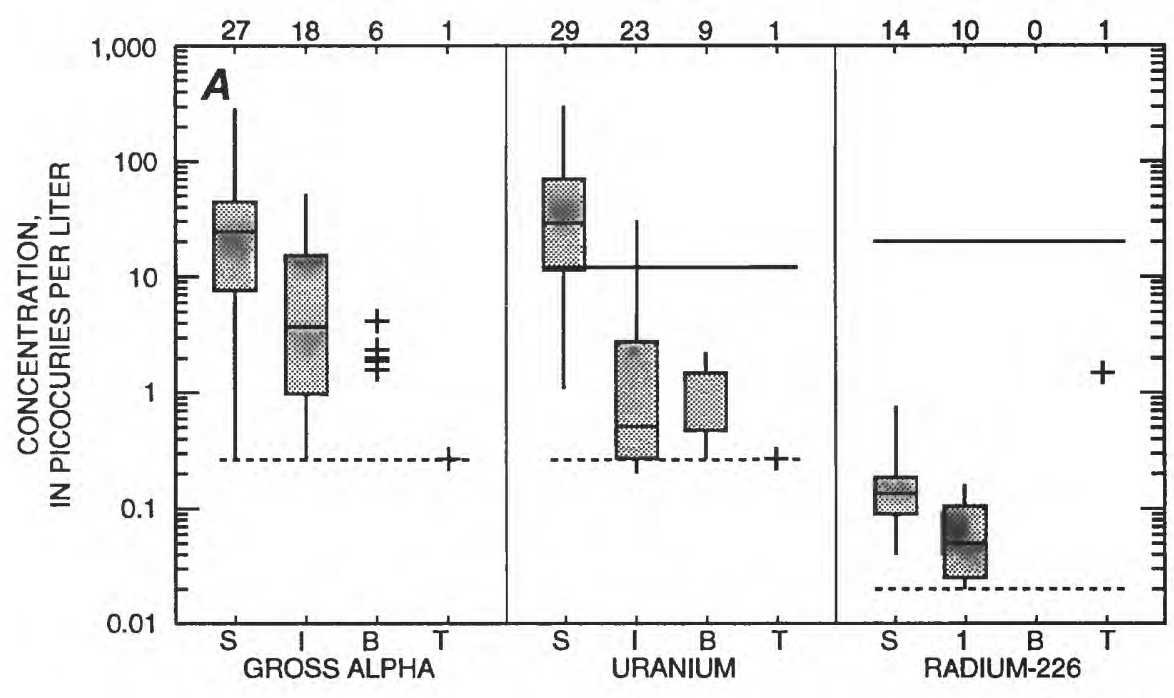

EXPLANATION

NUMBER OF ANALYSES
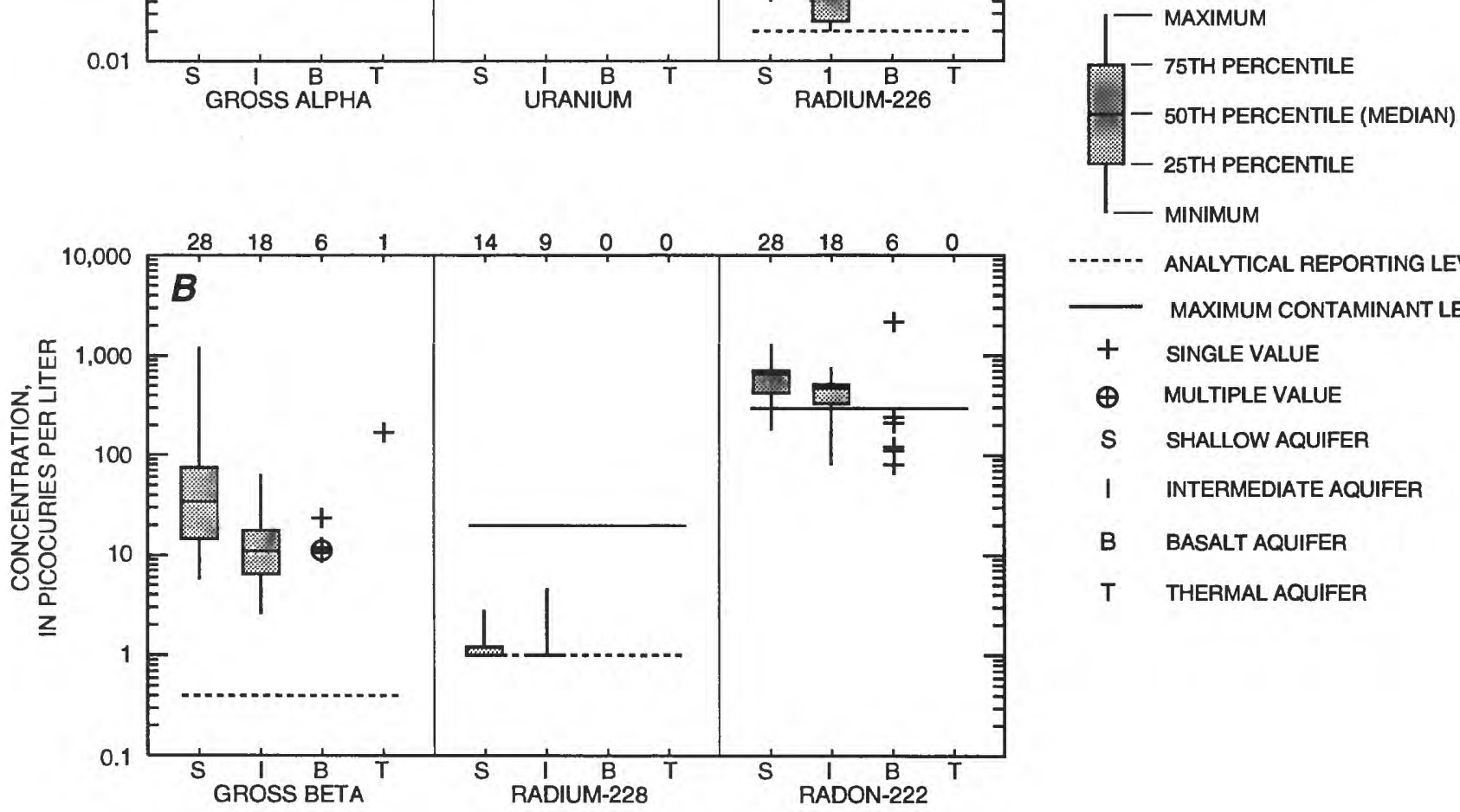

ANALYTICAL REPORTING LEVEL

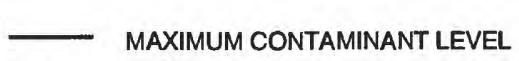

+ single value

$\oplus$ Multiple Value

S SHALLOW AQUIFER

I INTERMEDIATE AQUIFER

B BASALT AQUIFER

T THERMAL AQUIFER

Figure 29. Radioactivity caused by $A$, gross alpha, uranium, and radium-226, and $B$, gross beta, radium-228, and radon-222 in ground water in the Carson Desert. 
The greatest concentrations are in wells at sites 88 and 94 (fig. 3) in the western part of the Carson Desert (fig. 32). The radon-222 concentration in the basalt aquifer ranges from less than 80 to $2,200 \mathrm{pCi} / \mathrm{L}$. The highest concentration is at site 52 (fig. 3 ), which as mentioned previously, draws water from the intermediate and the basalt aquifers. The maximum radon concentration found in water samples from wells that tap only the basalt aquifer was $240 \mathrm{pCi} / \mathrm{L}$.
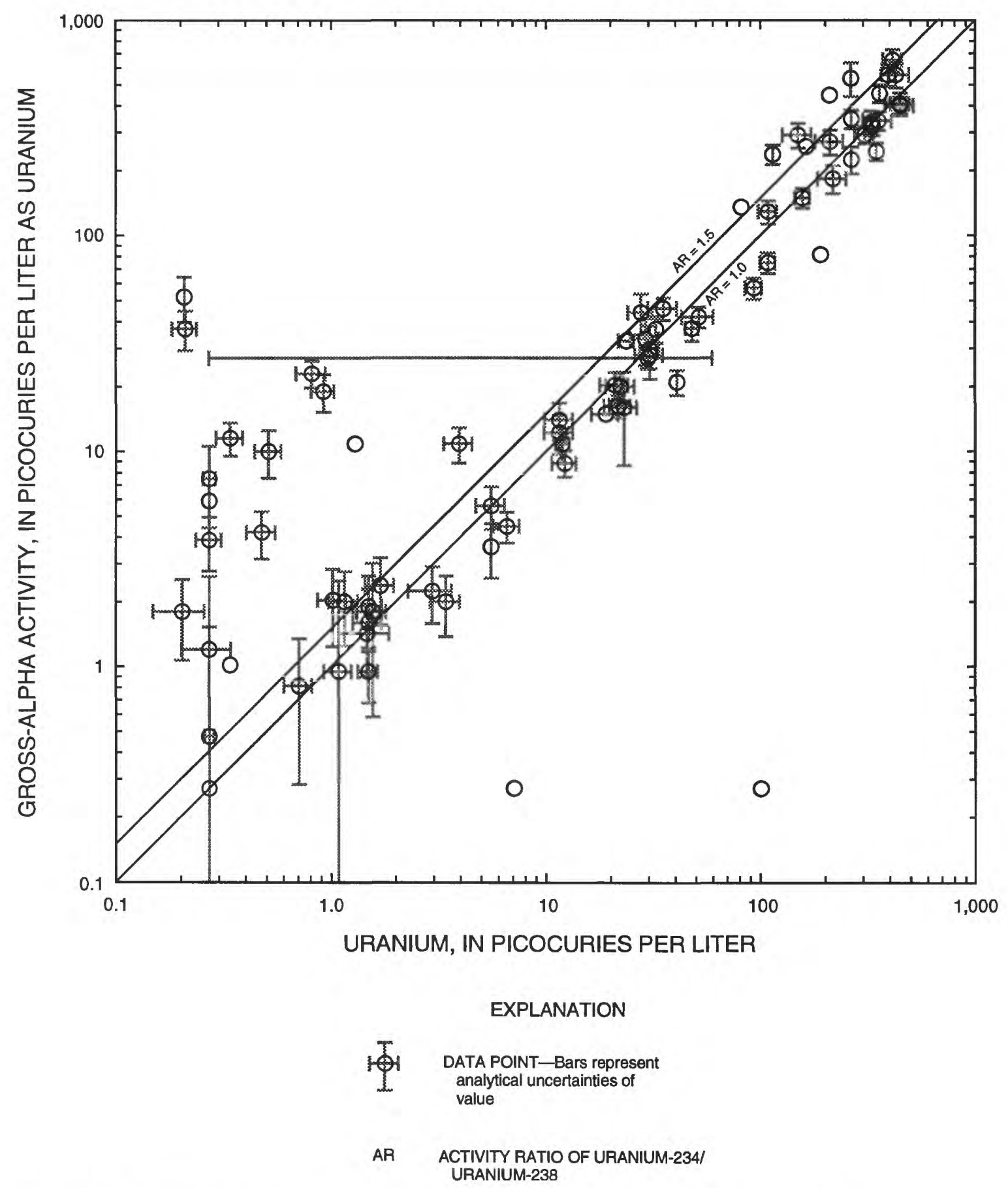

Figure 30. Relation between uranium concentrations and gross-alpha activity in ground water in Carson Desert. 


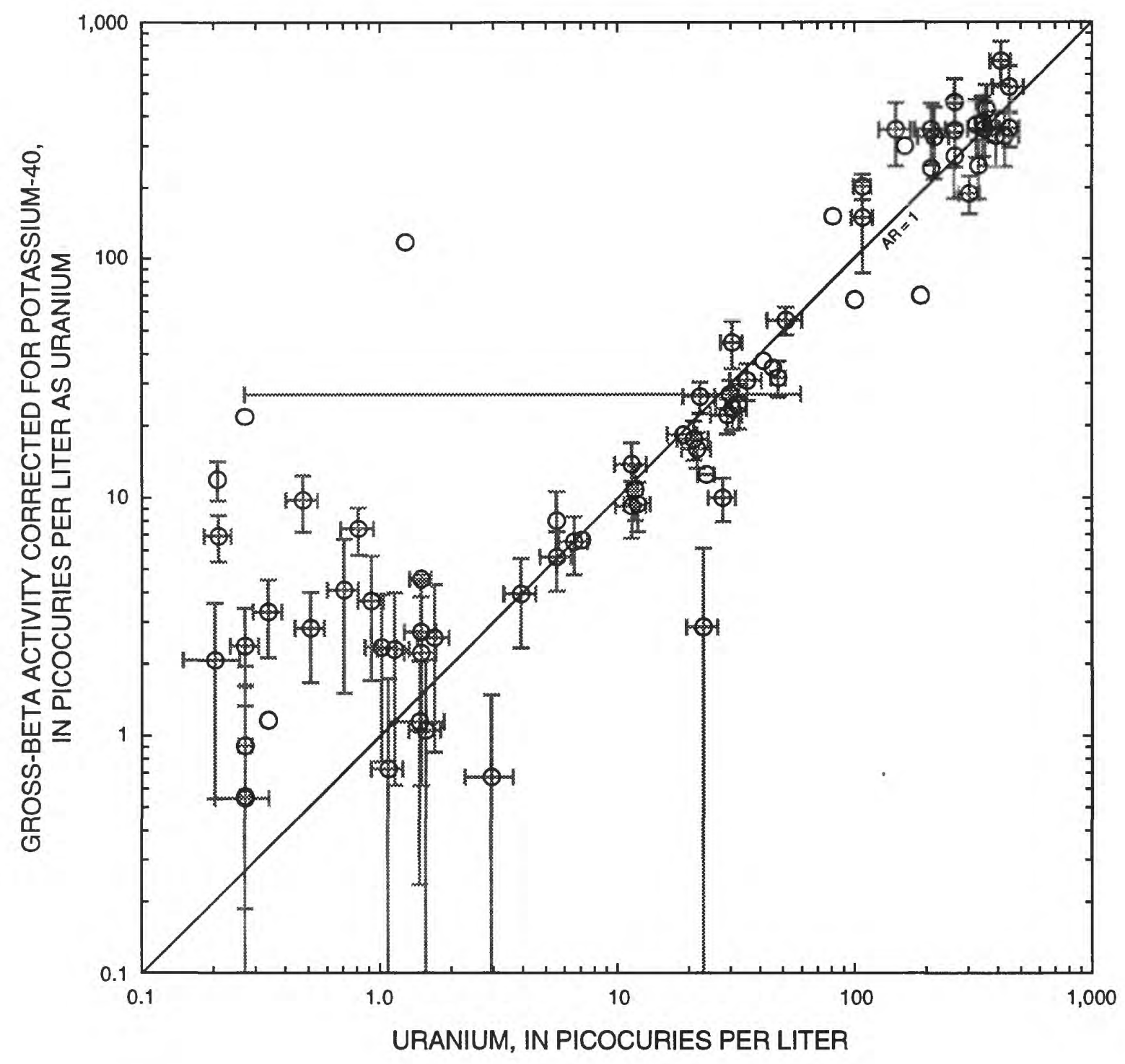

EXPLANATION

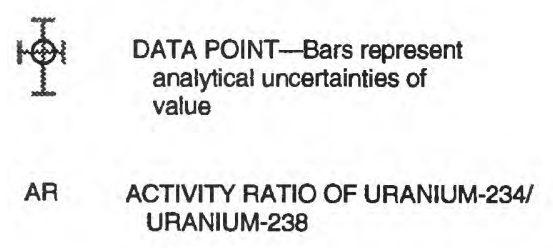

Figure 31. Relation between uranium concentrations and gross-beta activity minus estimated contribution from potassium- 40 in ground water in the Carson Desert. 


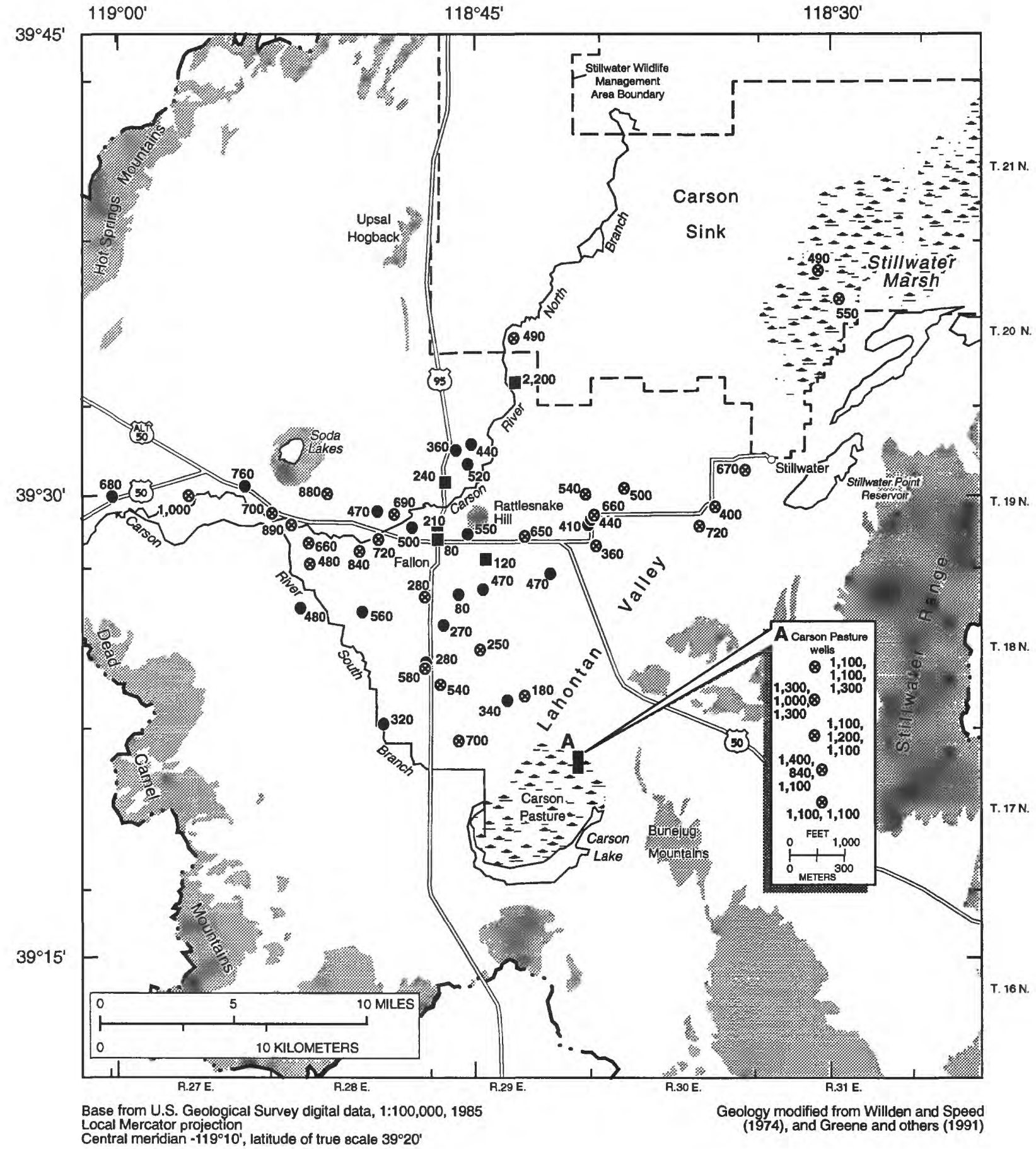

EXPLANATION
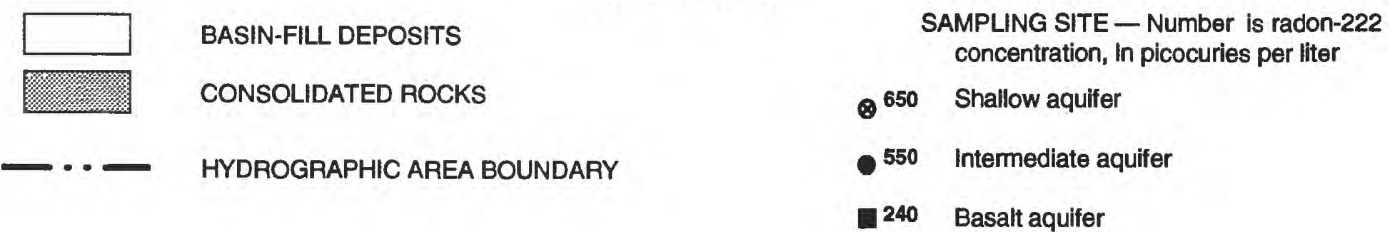

Figure 32. Radon-222 concentrations in ground water at selected sites. 
Uranium and radon-222 concentrations and gross-alpha activity commonly exceed the proposed MCL's (table 10). Thirty-one sites have uranium concentrations that are in excess of the proposed USEPA standard of $20 \mu \mathrm{g} / \mathrm{L}$ (fig. 33). Many of these sites are located in the peripheral parts of the area where samples were collected, such as the Stillwater Wildlife Management Area and Carson Pasture, and are not used as public supply sources. Gross-alpha activity exceeds proposed USEPA standards $(15 \mathrm{pCi} / \mathrm{L})$ at 9 of 56 sites. Radon- 222 is the only other radionuclide that exceeds its proposed MCL. Radon- 222 concentrations are greater than the proposed standard of $300 \mathrm{pCi} / \mathrm{L}$ at 41 of 52 sites sampled. Most of the sites that exceed the radon-222 MCL are wells completed in the shallow and intermediate aquifers (table 10).

\section{Processes Affecting Concentrations of Radionuclides}

A conceptual model explaining the observed uranium and radon-222 concentrations in ground water of the Carson River Basin has been proposed by Thomas and others (1993). Much of the uranium in ground water originates in the granitic and silicic volcanic rocks of the Carson River Basin. In oxygenated water, some of the uranium is concentrated in iron and manganese-oxide coatings on the sediment. Sediment, with uranium-rich oxide coatings, is transported by the Carson River and deposited in the Carson Desert. In oxygen-poor environments, such as where sedimentary organic matter is present, uranium is reduced and adsorbed onto the organic matter. These processes have, most likely, been taking place since the Late Tertiary in western Nevada providing a large source of uranium in the basin-fill deposits of Carson Desert. These shallow sediments have been mostly unsaturated since the last desiccation of Lake Lahontan (about 4,000 years ago), except for the discharge areas near Stillwater and Carson Lake. With the rise in the water table as a consequence of large-scale irrigation in the Fallon area, and inundation of these previously unsaturated sediments, dissolution of iron and manganese-oxide coatings is releasing uranium to the ground water. Uranium also is released by the reaction of uranium-rich organic matter with the oxide coatings. There also may be an increase in uranium concentrations in the shallow aquifers by evaporative concentration of the ground water.

Although radon-222 commonly exceeds the proposed MCL, concentrations are much less than those in upstream basins of the Carson River Basin (Carson and Eagle Valleys). Radon-222 is produced by the radioactive decay of radium-226; however, radium-226 concentrations dissolved in water are not high enough to produce the radon- 222 concentrations observed in the ground water of the Carson Desert. The low mobility of radium-226, under conditions present in the aquifers of the Carson Desert, indicates that most radium-226 is located in the aquifer matrix adsorbed by oxide coatings on grains, clays, and organic matter. Thus, most of the radon-222 in the ground water is produced from radium-226 in the sediment.

Table 10. Total number of sites and radionuclide analyses that exceed Nevada State primary maximum contaminant levels and the maximum contaminant levels proposed by the U.S. Environmental Protection Agency in ground water

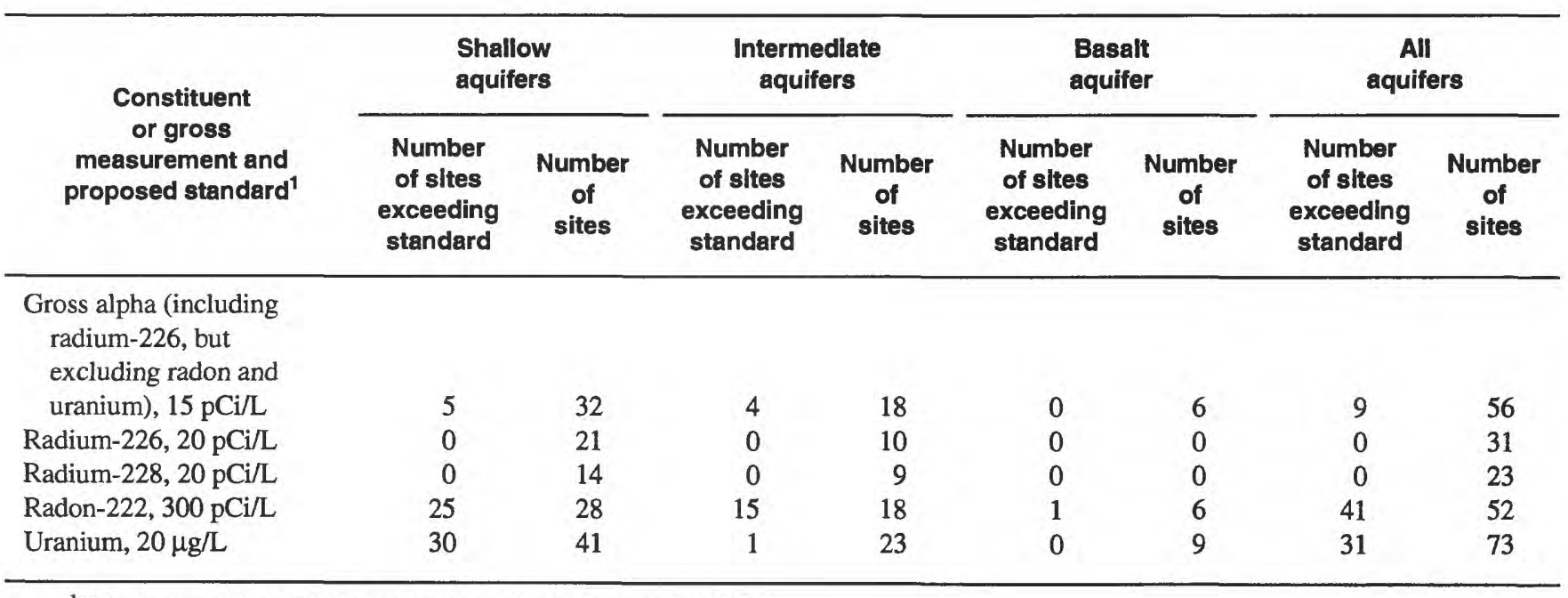

\footnotetext{
${ }^{1}$ Value proposed by the U.S. Environmental Protection Agency (1991).
} 


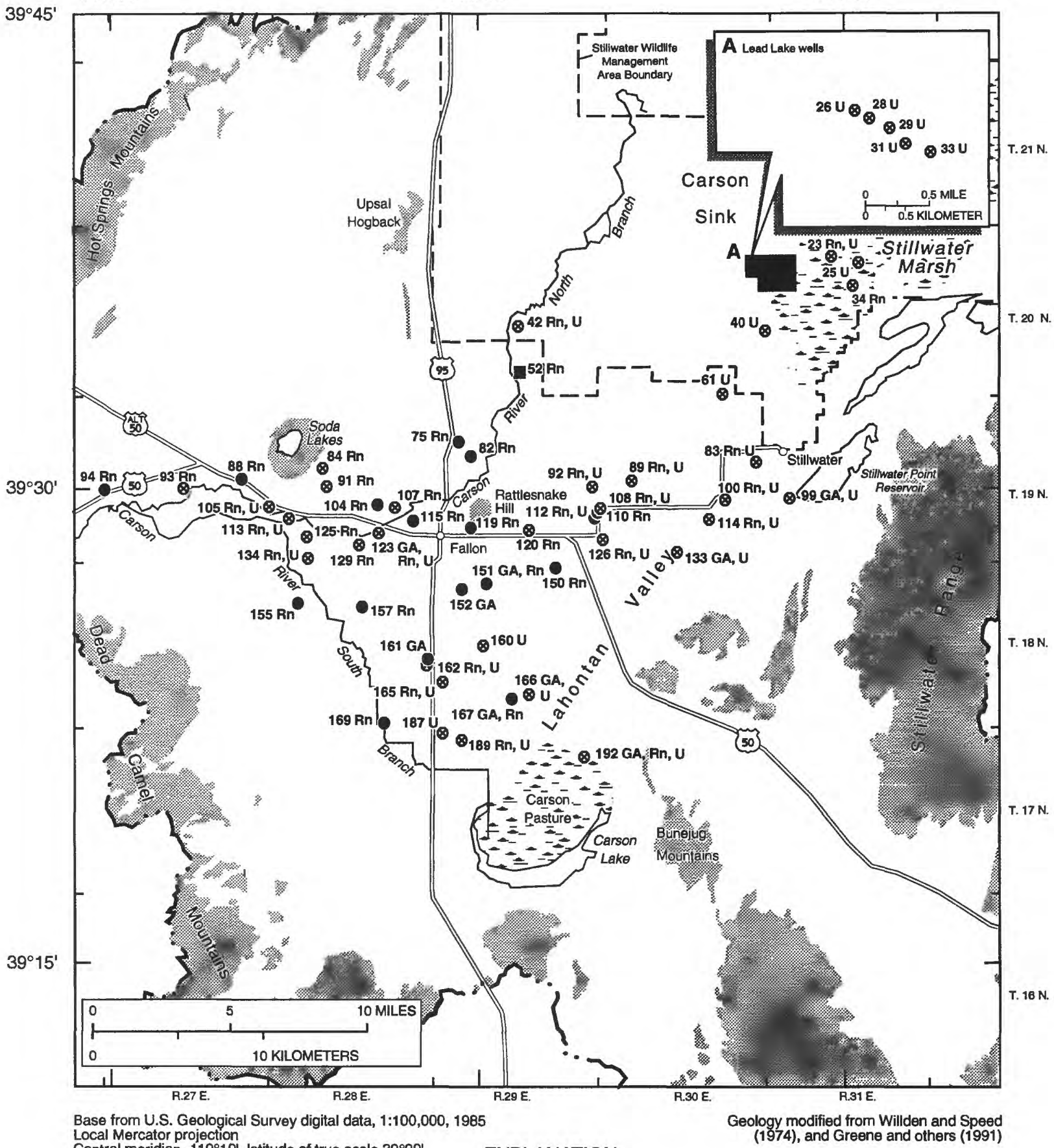

Central meridian $-119^{\circ} 10^{\prime}$, latitude of true scale $39^{\circ} 20^{\prime}$

\section{EXPLANATION}

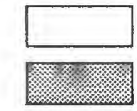

BASIN-FILL DEPOSITS

CONSOLIDATED ROCKS

HYDROGRAPHIC AREA BOUNDARY
SAMPLING SITE -

Number is site identifier

- ${ }^{40 \mathrm{U}}$ Shallow aquifer

- ${ }^{88}$ Rn Intermediate aquifer

$52 \mathrm{Rn}$ Basalt aquifer

Figure 33. Wells that exceed proposed U.S. Environmental Protection Agency maximum contaminant levels for radionuclides in ground water. 


\section{Synthetic Organic Compounds}

Synthetic organic compounds are becoming increasingly prevalent in aquifers that are prone to contamination by human activities on the land. As part of the NAWQA program, wells in the Carson Desert were sampled for selected herbicides, pesticides, and volatile organic compounds (table 11). These data can be found in a report by Whitney (1994). In all, 6 wells in the basalt aquifer, 19 wells in the intermediate aquifers, and 26 wells in the shallow aquifers were sampled for volatile organic compounds. Only wells completed in the shallow aquifers (19 wells) were sampled for herbicides and pesticides. Previously collected data, prior to 1988 , were summarized by Welch and others (1989).

Aquifers in the Carson Desert Basin appear to have so far escaped widespread contamination with synthetic organic compounds by human activities. Types and quantities of pesticides applied in the Carson Desert are not well known. Aerial applicators of pesticides are the only users required to report quantities of compounds used. Welch and others (1989) list pesti- cides applied aerially in the Carson Desert. Of the 51 sites where data were collected, only one site (site 84, fig. 3) had detectable concentrations of volatile organic compounds. This site, in the shallow aquifer near Soda Lakes, had 1,2-Dichloroethane present at a concentration of $1.0 \mu \mathrm{g} / \mathrm{L}$. No other volatile organic compounds were found in any sample analyzed from the Carson Desert. Herbicides and pesticides were detected at low concentrations in a few water samples from the shallow aquifer. Four samples contained detectable concentrations (maximum of $0.02 \mu \mathrm{g} / \mathrm{L}$ ) of Dicamba. Silvex, Simazine, and 2,4-D were detected in one sample each at concentrations of $0.01,0.1$, and $0.07 \mu \mathrm{g} / \mathrm{L}$, respectively. These low concentrations of synthetic organic compounds may be the result of contamination during sample collection. However, ground water at the Fallon Naval Air Station is contaminated by hydrocarbons from spills of jet fuel and solvents used on the base (Nevin Caine, Nevada Division of Environmental Protection, oral commun., 1991). Contamination appears to be restricted to the confines of the base, but sampling was not done as part of the NAWQA program to confirm this possibility. 


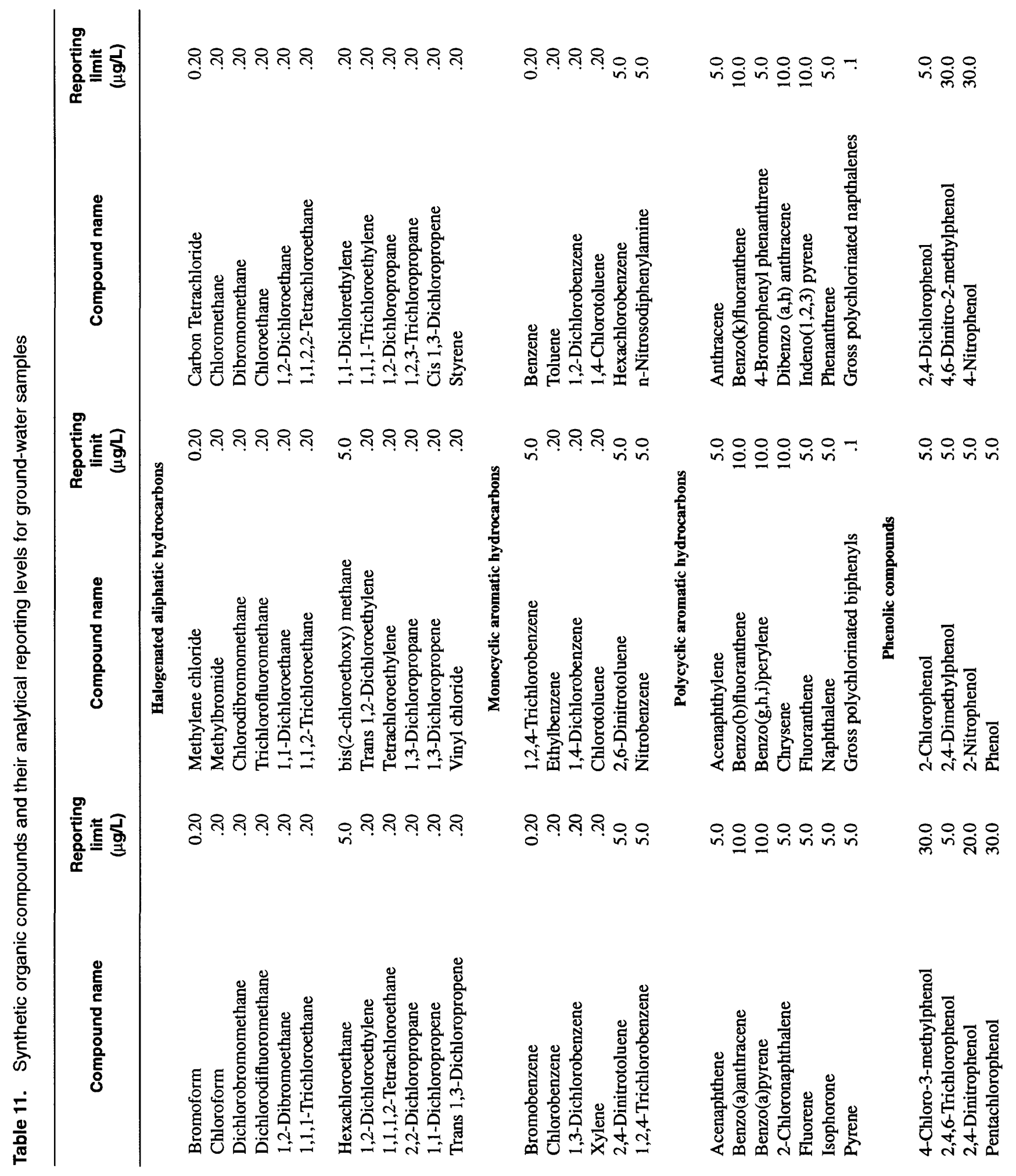




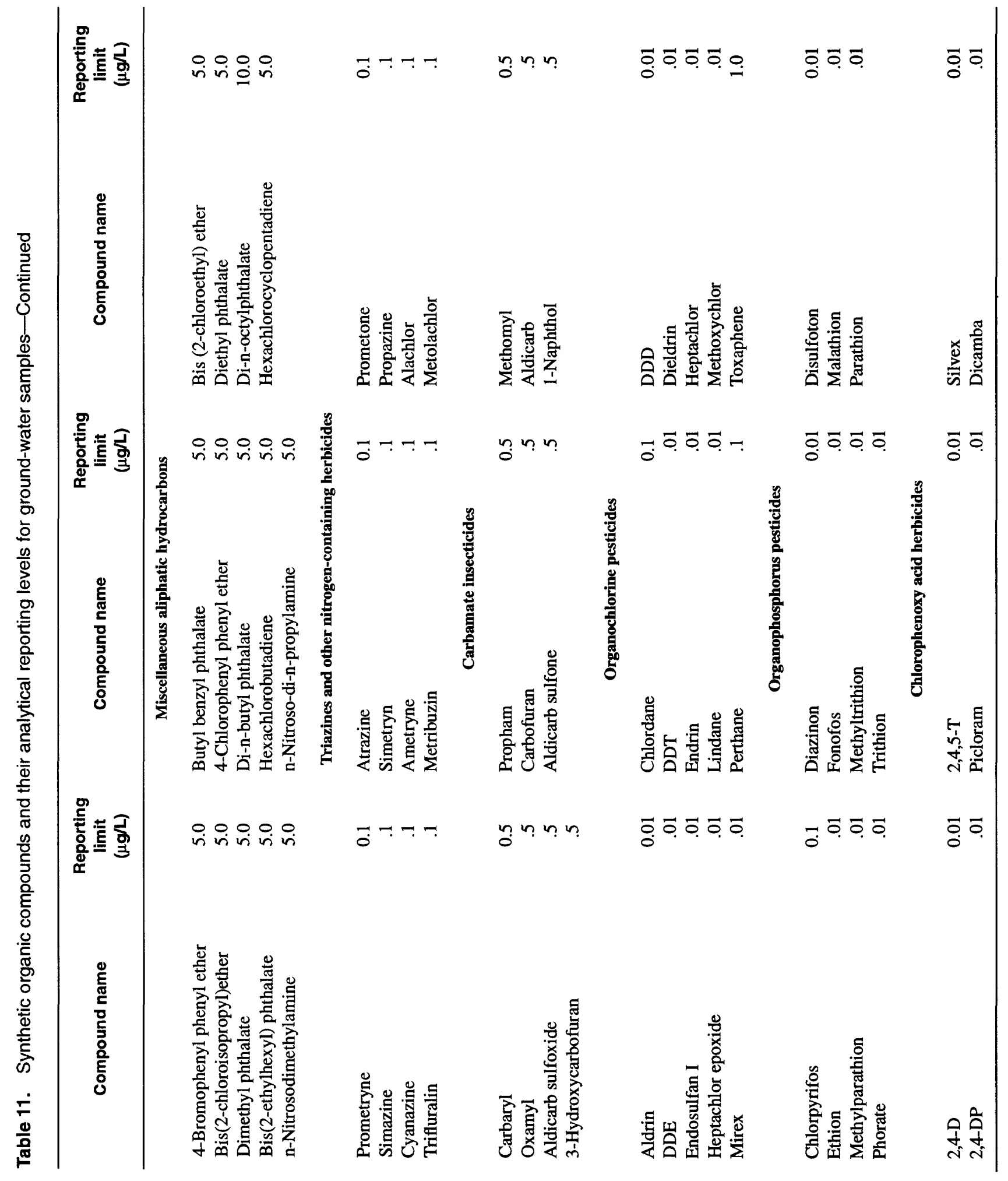




\section{SUMMARY AND CONCLUSIONS}

The basin-fill (mostly alluvial and lacustrine deposits) and basalt aquifers that underlie the Carson Desert are the primary source of public supply for the area. The city of Fallon and the Fallon Naval Air Station derive all of their water supply from the basalt aquifer directly beneath the town. Most of the residents in rural areas of the Carson Desert obtain their water from wells completed in the shallow and intermediate basin-fill aquifers. The sedimentary deposits in the Carson Desert may be as thick as $8,000 \mathrm{ft}$, although only the upper $500 \mathrm{ft}$ or so have been used for water supplies. These basin sediments are, in downward succession: (1) Holocene post-Lake Lahontan interbedded fluvial and eolian sediments;

(2) Pleistocene sediments of Lake Lahontan;

(3) Quaternary and Tertiary sedimentary and volcanic rocks; and (4) pre-Tertiary igneous and sedimentary rocks. The Carson Desert is surrounded by mountains composed of a wide variety of igneous, sedimentary, and metamorphic rocks that range in age from Triassic to Quaternary.

The principal source of recharge to the basin-fill aquifers is infiltration from the numerous river channels, canals, and ditches that crisscross the Carson Desert. This system of canals and ditches is part of the Newlands Project that delivers water from the Carson and Truckee Rivers to irrigate crops in the Carson Desert. Other sources of recharge to the ground-water system include infiltration of irrigation water, local ponding of precipitation in low-lying areas after intense storms, and precipitation in the surrounding mountain ranges. On the basis of stable-isotope composition of their waters, the present day Carson and Truckee Rivers are not the principal source of water for the basalt and intermediate aquifers. Waters from most of the wells in the intermediate aquifer and all of the wells in the basalt aquifer have ${ }^{14} \mathrm{C}$ ages of more than 1,000 years. Tritium concentrations indicate that some water from the canals is reaching the basalt aquifer; however, canal water probably is only a minor component of water recharging the basalt aquifer. Ground water generally flows to the northeast (towards Stillwater Wildlife Management Area), south (towards Carson Lake), and to the southeast (towards Fourmile and Eightmile Flats). Ground-water levels have risen by as much as $60 \mathrm{ft}$ in the Carson Desert because of the irrigation of more than 60,000 acres of croplands since the early 1900 's.
Water in the Carson River just below Lahontan Reservoir (recharge water for the basin-fill aquifers) generally has $\mathrm{pH}$ values ranging from near neutral to alkaline with dissolved-solids concentrations that are less than $300 \mathrm{mg} / \mathrm{L}$. Sodium, calcium, and bicarbonate are the dominant ions in the water.

Ground water in the aquifers of the Carson Desert is highly variable in composition and quality. Ground water varies from a dilute calcium bicarbonate type water to a saline sodium chloride type. Generally, the more dilute water is beneath the irrigated areas and the more concentrated water is in unirrigated areas (such as Stillwater and Carson Lake). Many (more than 50 percent) of the ground-water samples included in this report have dissolved-solids concentrations that exceed Nevada State drinking-water standards. Many of the wells from which the sample were collected, however, are observation wells and are located in areas where few people live. Many of these same wells have ground water that exceeds standards for chloride, magnesium, and sulfate. Water from a few sites exceeds standards for fluoride (32 sites), nitrate ( 3 sites), and selenium (5 sites). Arsenic concentrations commonly exceed primary drinking-water standards (98 sites out of 172). Water from basalt aquifer, the primary drinking-water source for the city of Fallon, has arsenic concentrations that exceed the MCL in all cases. Manganese concentrations in water from the basin-fill aquifers commonly exceed the SMCL by more than 30 percent of samples.

The major-constituent concentrations in ground water of the aquifers beneath Carson Desert are the result of natural geochemical reactions with minerals derived mostly from igneous rocks. Evaluation of mass-balance reactions, combined with thermodynamic and mineralogic data, is consistent with majorconstituent concentrations being the result of reaction with plagioclase feldspar, calcite, augite, carbon dioxide, beidellite, and small amounts of potassium feldspar, gypsum, silica, sodium chloride, and pyrite. The exchange of calcium for sodium on clay minerals also is a common process in all geochemical reactions determined in the study.

Dissolved oxygen concentrations appear to be the major control on iron and manganese concentrations in the ground water of Carson Desert. Higher concentrations of these metals are caused primarily by the increased solubility of the chemically reduced forms of these elements which can be present at low dissolved oxygen concentrations. Dissolved oxygen is 
consumed by reaction with dissolved organic carbon in the shallow aquifer. The waters with higher concentrations of iron and manganese are near thermodynamic equilibrium with siderite and rhodochrosite. This relation indicates that the concentrations of these elements may be limited by the solubility of their respective carbonate minerals. The change in redox conditions because of the rise in the water table from irrigation may result in lower dissolved oxygen, dissolution of iron and manganese oxides, and release of trace elements associated with the oxides.

Naturally occurring radionuclides are present in ground water from the Carson Desert in concentrations that are higher than proposed USEPA drinking-water standards. Uranium and radon-222 are the two radionuclides that most commonly exceed these standards. Uranium exceeds standards in samples from 31 of 73 wells and radon- 222 exceeds standards in 41 of 52 wells. Uranium concentrations are highest in water from the shallow aquifers. Gross-alpha activities exceed proposed USEPA standards in water from 9 of 56 wells.

High concentrations of dissolved uranium may be caused by its release when iron and manganese oxides dissolve in the shallow aquifers. Another possible source for uranium may be the oxidation of sedimentary organic matter which typically has elevated concentrations of uranium. Dissolved uranium concentrations appear to be high enough to account for the observed gross-alpha activities. High concentrations of radon-222 in the ground water are not the result of dissolved radium-226 concentrations in the water. This lack of correlation indicates that radium226 must be present in grain coatings or some other mineral form and that the radon- 222 is coming from this solid-phase source.

Ground water in the Carson Desert appears to have escaped gross contamination by synthetic organic chemicals. A water sample from 1 site in the shallow basin-fill aquifers has a detectable concentration of 1,2-Dichloroethane, but does not exceed drinkingwater standards. No other volatile organic compounds were detected in samples from the Carson Desert. Ground water at 4 sites in the shallow aquifer has Dicamba present at detectable concentrations. Silvex, Simazine, and 2,4-D were detected once each in ground-water samples from 3 different sites.

\section{REFERENCES CITED}

Ball, J.W., Nordstrom, D.K., and Zachmann, D.W., 1987, WATEQ4F-A personal computer FORTRAN translation of the geochemical model WATEQ2 with revised data base: U.S. Geological Survey Open-File Report 87-50, $108 \mathrm{p}$.

Cerling, T.E., 1984, The stable isotopic composition of modern soil carbonate and its relationship to climate: Earth and Planetary Science Letters, v. 71, p. 229-240.

Craig, Harmon, 1961, Standard for reporting concentrations of deuterium and oxygen-18 in natural water: Science, v. 133 , p. $1833-1834$.

Davis, J.O., 1982, Bits and pieces: The last 35,000 years in the Lahontan area, in Madsen, D.B., and O'Connell, J.F., eds., Lahonton Basin paleoenvironments, Man and environment in the Great Basin: Society for American Archaeology Papers, no. 2, p. 53-75.

Deines, Peter, 1980, The isotopic composition of reduced organic carbon, in Fritz, Peter, and Fontes, JeanCharles, eds., Handbook of environmental isotope geochemistry: New York, Elsevier, v. 1, chap. 9, p. 329-406.

Dollarhide, W.E., 1975, Soil survey, Fallon-Fernley area, parts of Churchill, Lyon, Storey, and Washoe Counties: Washington D.C., U.S. Department of Agriculture, $112 \mathrm{p}$.

Drever, J.I., 1982, The geochemistry of natural waters: Englewood Cliffs, N.J., Prentice-Hall, 388 p.

Fishman, M.J., and Friedman, L.C., 1985, Methods for determination of inorganic substances in water and fluvial sediments: U.S. Geological Survey Techniques of Water-Resources Investigations, Book 5, Chap. A1, $709 \mathrm{p}$.

Fontes, Jean-Charles, 1980, Environmental isotopes in groundwater hydrology, in Fritz, Peter, and Fontes, Jean-Charles, eds., Handbook of environmental isotope geochemistry: New York, Elsevier, v. 1, chap. 3, p. 75-135.

Friedlander, Gerhart, Kennedy, J.W., Macias, E.S., and Miller, J.M., 1981, Nuclear and radiochemistry (3d ed.): New York, John Wiley, 684 p.

Fritz, Peter, and Fontes, Jean-Charles, 1980, Introduction, in Fritz, Peter, and Fontes, Jean-Charles, eds., Handbook of environmental isotope geochemistry: New York, Elsevier, v. 1, p. 1-20.

Garside, L.J., and Schilling, J.H., 1979, Thermal waters of Nevada: Nevada Bureau of Mines and Geology Bulletin 91, $163 \mathrm{p}$.

Glancy, P.A., 1986, Geohydrology of the basalt and unconsolidated sedimentary aquifers in the Fallon area, Churchill County, Nevada: U.S. Geological Survey Water-Supply Paper 2263, 62 p. 
Glancy, P.A., and Katzer, T.L., 1975, Water-resources appraisal of the Carson River basin, western Nevada: Nevada Division of Water Resources, Reconnaissance Report 59, $126 \mathrm{p}$.

Greene, R.C., Stewart, J.H., John, D.A., Hardyman, R.F., Silberling, N.J., and Sorenson, M.L., 1991, Geologic map of the Reno $1^{\circ}$ by $2^{\circ}$ quadrangle, Nevada and California: U.S. Geological Survey Map Folio MF-2154-A.

Hallock, R.J., and Hallock, L.L., eds., 1993, Detailed study of irrigation drainage in and near wildlife management areas, west-central Nevada, 1987-90. Part B-Effect on biota in Stillwater and Fernley Wildlife Managment Areas and other nearby wetlands: U.S. Geological Survey Water-Resources Investigations Report 92-4024B, 84 p.

Hardy, M.A., Leahy, P.P., and Alley, W.M., 1989, Well installation and documentation, and ground-water sampling protocols for the pilot National Water-Quality Assessment Program: U.S. Geological Survey Open-File Report 89-396, 36 p.

Hem, J.D., 1985, Study and interpretation of the chemical characteristics of natural water [ $3 \mathrm{~d}$ ed.]: U.S. Geological Survey Water-Supply Paper 2254, $283 \mathrm{p}$.

Hirsch, R.M., Alley, W.M., and Wilber, W.G., 1988, Concepts for a National Water-Quality Assessment Program: U.S. Geological Survey Circular 1021, 42 p.

Hoffman, R.J., 1994, Detailed study of irrigation drainage in and near wildlife management areas, west-central Nevada, 1987-90. Part C-Summary of irrigationdrainage effects on water quality, bottom sediment, and biota: U.S. Geological Survey Water-Resources Investigations Report 92-4024C, 32 p.

Hoffman R.J., Hallock, R.J., Rowe, T.G., Lico, M.S., Burge, H.L., and Thompson, S.P., 1990, Reconnaissance investigation of water quality, bottom sediment, and biota associated with irrigation drainage near Stillwater Wildlife Management Area, Churchill County, Nevada, 1986-87: U.S. Geological Survey Water-Resources Investigations Report 89-4105, 150 p.

Houghton, J.G., Sakamoto, C.M., and Gifford, R.O., 1975, Nevada's weather and climate: Nevada Bureau of Mines and Geology Special Publication 2, 78 p.

Ishihara, Shunso, and Sasaki, Akira, 1989, Sulfur isotopic ratios of the magnetic-series and ilmenite series granitoids of the Sierra Nevada batholith-A reconnaissance study: Geology, v. 17, no. 9, p. 788-791.

Jacobson, R.L., Ingraham, N.L., and Campana, M.E., 1983, Isotope hydrology of a Basin and Range geothermal system: Desert Research Institute Water Resources Center Project Report 87, 18 p.
Jenne, E.A., 1968, Controls on $\mathrm{Mn}, \mathrm{Fe}, \mathrm{Co}, \mathrm{Ni}, \mathrm{Cu}$, and $\mathrm{Zn}$ concentrations in soils and water-The significant role of hydrous $\mathrm{Mn}$ and $\mathrm{Fe}$ oxides, in Gould, R.F., ed., Advances in chemistry series: Washington D.C., American Chemical Society, v. 73, p. 337-387.

Jones, B.F., and Bowser, C.J., 1978, The mineralogy and related chemistry of lake sediments, chap. 7, in Lerman, Abraham, ed., Lakes: chemistry, geology, physics: New York, Springer-Verlag, p. 179-235.

Lachenbruch, A.H., and Sass, J.H., 1978, Models of an extending lithosphere and heat flow in the Basin and Range province: Geological Society of America Memoir 152, p. 209-250.

Lawrence, S.J., and Whitney, Rita, 1990, Shallow groundwater quality in the vicinity of a small urban area in West-Central Nevada [abs.], in Nevada decision point-Which water course to the future?: Annual Conference, Nevada Water Resources Association, Las Vegas, Nev., February 1990, Program Information and Abstracts, unpaginated.

Lico, M.S., 1992, Detailed study of irrigation drainage in and near wildlife management areas, west-central Nevada, 1987-90. Part A - Water quality, sediment composition, and hydrogeochemical processes in Stillwater and Fernley Wildlife Management Areas: U.S. Geological Survey Water-Resources Investigations Report 92-4024A, 65 p.

Lico, M.S., Welch, A.H., and Hughes, J.L., 1986, Hydrologic, lithologic, and chemical data for sediment in the shallow alluvial aquifer at two sites near Fallon, Churchill County, Nevada, 1984-85: U.S. Geological Survey Open-File Report 86-250, 43 p.

1987 , Geochemistry of ground water in the shallow alluvial aquifer Carson Desert, western Nevada, in Averett, R.C., and McKnight, D.M., eds., Chemical quality of water and the hydrologic cycle: Chelsea, Mich., Lewis Publishers, p. 89-109.

Magaritz, Mordeckai, and Luzier, J.E., 1985, Water-rock interactions and seawater-freshwater mixing effects in the coastal dunes aquifer, Coos Bay, Oregon: Geochimica et Cosmochimica Acta, v. 49, p. 2515-2525.

May, H.M., Kinniburgh, D.G., Helmke, P.A., and Jackson, M.L., 1986, Aqueous dissolution, solubilities, and thermodynamic stabilities of common aluminosilicate clay minerals: Kaolinite and smectites: Geochimica et Cosmochimica Acta, v. 50, no.8, p. 1667-1677.

Morgan, D.S., 1982, Hydrogeology of the Stillwater geothermal area, Churchill County, Nevada: U.S. Geological Survey Open-File Report 82-345, 94 p.

Morrison, R.B., 1964, Lake Lahontan-Geology of southern Carson Desert, Nevada: U.S. Geological Survey Professional Paper 401, $156 \mathrm{p}$. 
Nevada Bureau of Consumer Health Protection Services, 1980, Water supply regulations-part 1, water-quality standards-monitoring, recordkeeping, and reporting: Nevada Division of Health, 16 p.; appendix A, 11 p.

Ohmoto, Hiroshi, and Rye, R.O., 1979, Isotopes of sulfur and carbons, in Barnes, H.L., ed., Geochemistry of hydrothermal ore deposits: New York, John Wiley, p. 509-567.

Olmsted, F.H., 1985, Ground-water discharge and recharge in the Soda Lakes and Upsal Hogback geothermal areas, Churchill County, Nevada: U.S. Geological Survey Water-Resources Investigation Report 85-4033, $27 \mathrm{p}$.

Olmsted, F.H., Welch, A.H., Van Denburgh, A.S., and Ingebritson, S.E., 1984, Geohydrology, aqueous geochemistry, and thermal regime of the Soda Lakes and Upsal Hogback geothermal system, Churchill County, Nevada: U.S. Geological Survey WaterResources Investigations Report 84-4054, 166 p.

Parkhurst, D.L., Plummer, L.N., and Thorstenson, D.C., 1982, Balance-A computer program for calculating mass transfer for geochemical reactions in groundwater: U.S. Geological Survey Open-File Report 82-14, 29 p.

Pennington, R.W., 1980, Evaluation of empirical methods for estimating crop water consumptive use for selected sites in Nevada: Nevada Division of Water Planning, Report 3, 206 p.

Plummer, L.N., Parkhurst, D.L., and Thorstenson, D.C., 1983, Development of reaction models for groundwater systems: Geochimica et Cosmochimica Acta, v. 47 , p. $665-686$.

Plummer, L.N., Prestemon, E.C., and Parkhurst, D.L., 1991, An interactive code (NETPATH) for modeling net geochemical reactions along a flow path: U.S. Geological Survey Water-Resources Investigations Report 91-4078, 227 p.

Quade, Jay, Cerling, T.E., and Bowman, J.R., 1989, Systematic variations in the carbon and oxygen isotopic composition of pedogenic carbonate along elevation transects in the southern Great Basin, United States: Geological Society of America Bulletin, v. 101, p. 464-475.

Rowe, T.G., and Hoffman, R.J., 1990, Wildlife kills in the Carson Sink, western Nevada, winter 1986-87, in Moody, D.W., Chase, E.B., and Aronson, D.A., compilers, National water summary, 1987-Hydrologic events and water supply and demand: U.S. Geological Survey Water-Supply Paper 2350, p. 37-40.

Rowe, T.G., Lico, M.S., Hallock, R.J., Maest, A.S., and Hoffman, R.J., 1991, Physical, chemical, and biological data for detailed study of irrigation drainage in and near Stillwater, Fernley, and Humboldt Wildlife
Management Areas and Carson Lake, west-central Nevada: U.S. Geological Survey Open-File Report 91-185, $199 \mathrm{p}$.

Rush, F.E., 1968, Index of Hydrographic Areas in Nevada: Nevada Division of Water Resources, Information Report 6, 38 p.

1972, Hydrologic reconnaissance of Big and Little Soda Lakes, Churchill County, Nevada: Nevada Division of Water Resources, Information Report 11, 1 sheet.

Sibbett, B.S., 1979, Geology of the Soda Lakes geothermal area: Salt Lake City, University of Utah, Earth Science Laboratory Report ESL-24, 27 p.

Thatcher, L.L., Janzer, V.J., and Edwards, K.W., 1977, Methods for determination of radioactive substances in water and fluvial sediments: U.S. Geological Survey Techniques of Water-Resources Investigations, Book 5 , Chap. A5, 95 p.

Thomas, J.M., and Lawrence, S.J., 1994, Ground-water quality and chemistry in Dayton and Churchill Valleys, western Nevada: U.S. Geological Survey Open-File Report 93-356, 69 p.

Thomas, J.M., Welch, A.H., and Gunderson, L.C.S., 1990, Distribution and sources of radon-222 in ground water in the Carson River basin, Nevada and California: Eos, v. 71, no. 43, p. 1305.

Thomas, J.M., Welch, A.H., Lico, M.S., Hughes, J.L., and Whitney, Rita, 1993, Radionuclides in ground water in the Carson River basin, western Nevada and eastern California, U.S.A.: Applied Geochemistry, v. 8, p. 447-471.

Thompson, S.P., and Merritt, K.L., 1988, Western Nevada wetlands-History and current status, in Blesse, R.E., and Goin, Peter, eds., Reno, University of Nevada, Nevada Public Affairs Review, no. 1, p. 40-45.

Tidball, R.R., Briggs, P.H., Stewart, K.C., Vaughn, R.B., and Welsch, E.P., 1991, Analytical data for soil and well core samples from the Carson River basin, Lyon and Churchill Counties, Nevada: U.S. Geological Survey Open-File Report 91-584A, 140 p.

Tukey, J.W., 1977, Exploratory data analysis: Menlo Park, Calif., Addison-Wesley, 688 p.

U.S. Bureau of Reclamation, 1986, Draft environmental impact statement for the Newlands Project proposed operating criteria and procedures: technical appendices, five numbered sections.

1987, Final environmental impact statement for the Newlands Project proposed operating criteria and procedures: Washington, D.C., 332 p.

U.S. Environmental Protection Agency, 1986a, Maximum contaminant levels (subpart B of part 141, National interim primary drinking-water regulations): U.S. Code of Federal Regulations, Title 40, Parts 100 to 149, revised as of July 1,1986, p. 524-528. 
1986b, Water pollution control; national primary drinking water regulations; radionuclides; advanced notice of proposed rulemaking: Federal Register, v. 51, no. 189 , p. $34836-34862$.

1986c, Secondary maximum contaminant levels (section 143.3 of part 143, National secondary drinking-water regulations): U.S. Code of Federal Regulations, Title 40 , parts 100 to 149 , revised as of July 1 , 1986, p. 587-590.

1991, Proposed rule for primary maximum contaminant levels for radionuclides: Federal Register, U.S. Code of Federal Regulations, July 18, 1991, v. 56, no. 38, p. 33050-33127.

Welch, A.H., 1994, Ground-water quality and geochemistry in Carson and Eagle Valleys, western Nevada and eastern California: U.S. Geological Survey Open-File Report 93-33, 99 p.

Welch, A.H., and Lico, M.S., 1988, Mobilization of arsenic in an alluvial-lacustrine aquifer in the arid west, in Ragone, S.E., ed., U.S. Geological Survey program on toxic waste-ground water contamination: U.S. Geological Survey Open-File Report 86-481, p. E-13-E-18.

Welch, A.H., Lico, M.S., and Hughes, J.L., 1988, Arsenic in ground water of the western United States: Ground Water, v. 26, no. 3, p. 333-347.

Welch, A.H., and Plume, R.W., 1987, Water-quality assessment of the Carson River ground-water basin, Nevada and California—Project description: U.S. Geological Survey Open-File Report 87-104, 27 p.
Welch, A.H., and Plume, R.W., Frick, E.A., and Hughes, J.L., 1989, Ground-water-quality assessment of the Carson River basin, Nevada and California-Analysis of available water-quality data through 1987: U.S.

Geological Survey Open-File Report 89-382, 115 p.

Welch, A.H., and Preissler, A.M., 1986, Aqueous geochemistry of the Brady's Hot Spring geothermal area, Churchill County, Nevada: U.S. Geological Survey Water-Supply Paper 2290, p. 17-36.

Welch, A.H., Thomas, J.M., and Gunderson, L.C.S., 1990, Distribution and sources of uranium in ground water in the Carson River Basin, Nevada and California: Eos, v. 71, no. 43, p. 1305.

Wershaw, R.L., Fishman, M.J., Grabbe, R.R., and Lowe, L.E., 1987, Methods for the determination of organic substances in water and fluvial sediments: U.S. Geological Survey Techniques of WaterResources Investigations, Book 5, Chap. A3, 80 p.

Whitney, Rita, 1994, Data on ground-water quality in the Carson River Basin, western Nevada and eastern California, 1987-90: U.S. Geological Survey Open-File Report 94-39, $139 \mathrm{p}$.

Willden, Ronald, and Speed, R.C., 1974, Geology and mineral deposits of Churchill County, Nevada: Nevada Bureau of Mines and Geology Bulletin 83, $95 \mathrm{p}$.

Zaporozec, Alexander, 1972, Graphical interpretation of water-quality data: Ground Water, v. 10, no. 2, p. 32-43. 


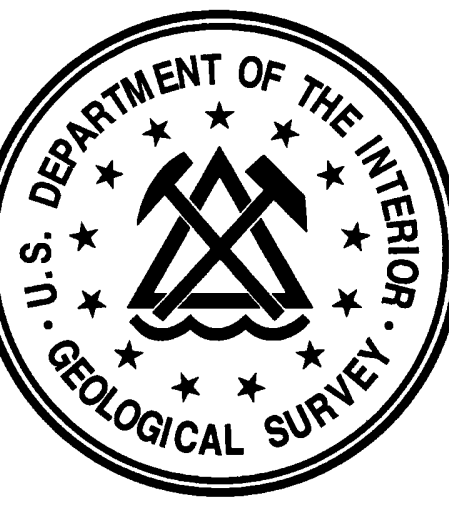


APPENDIX

- PAGE 85 fonows 83 


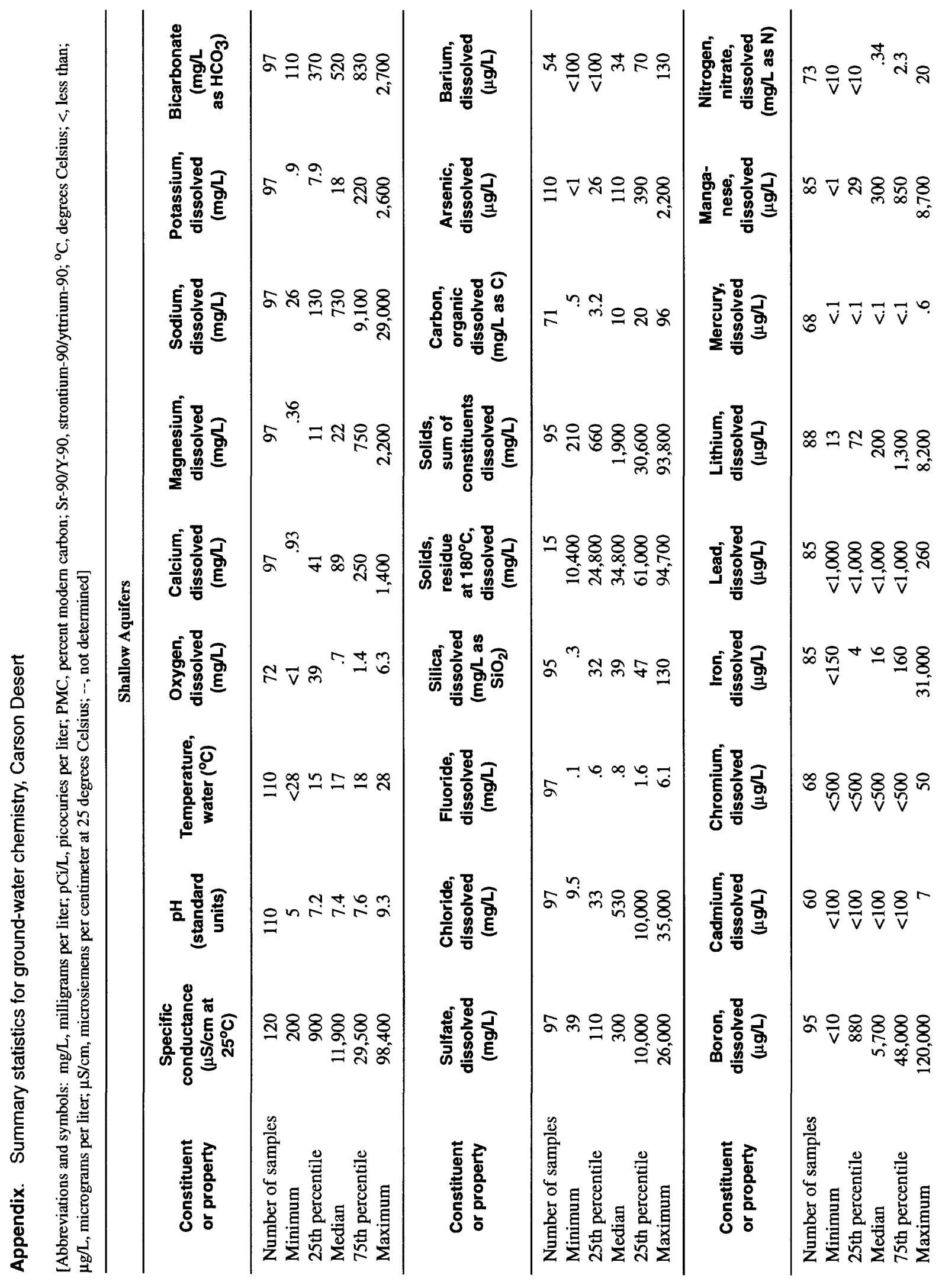




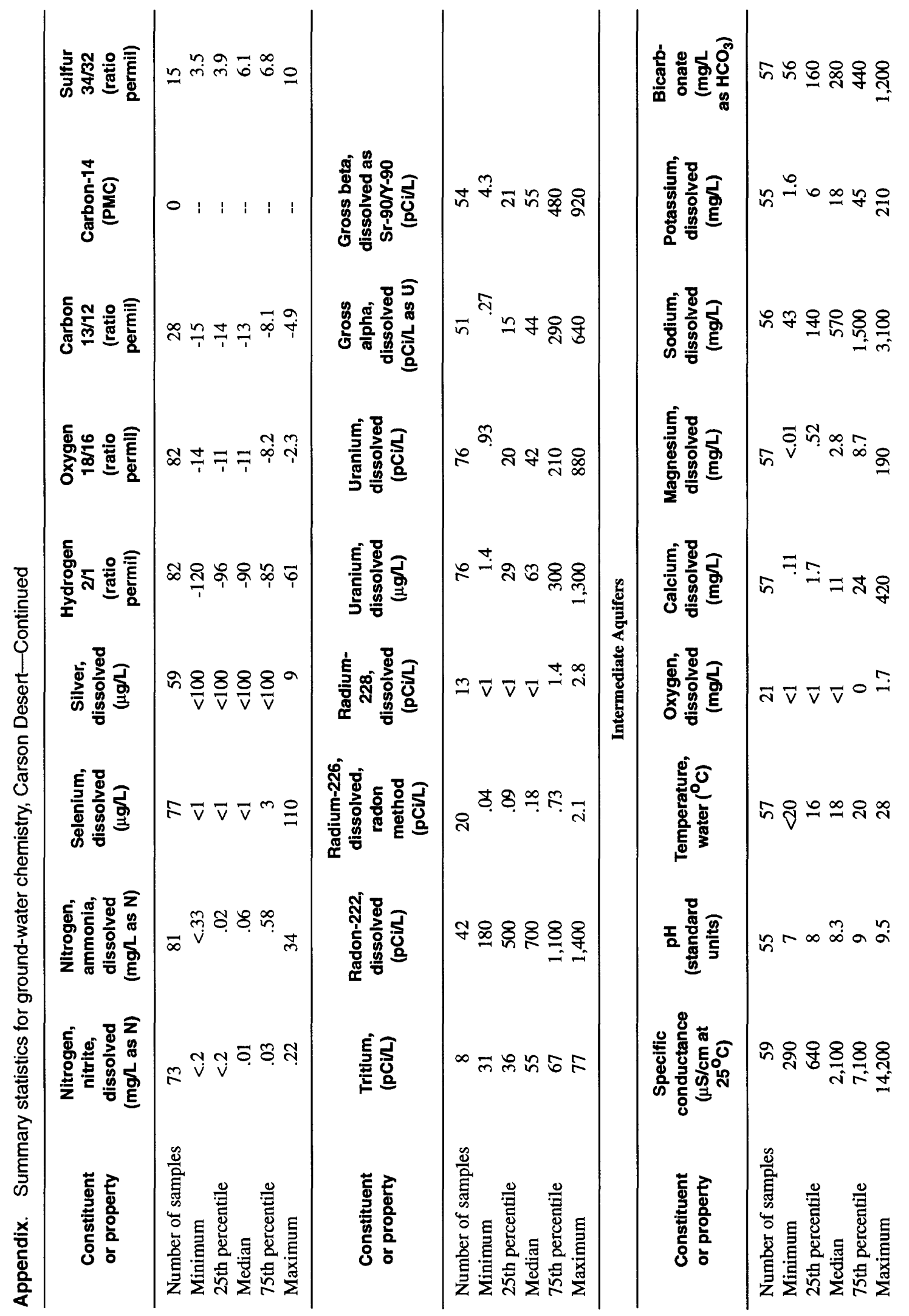




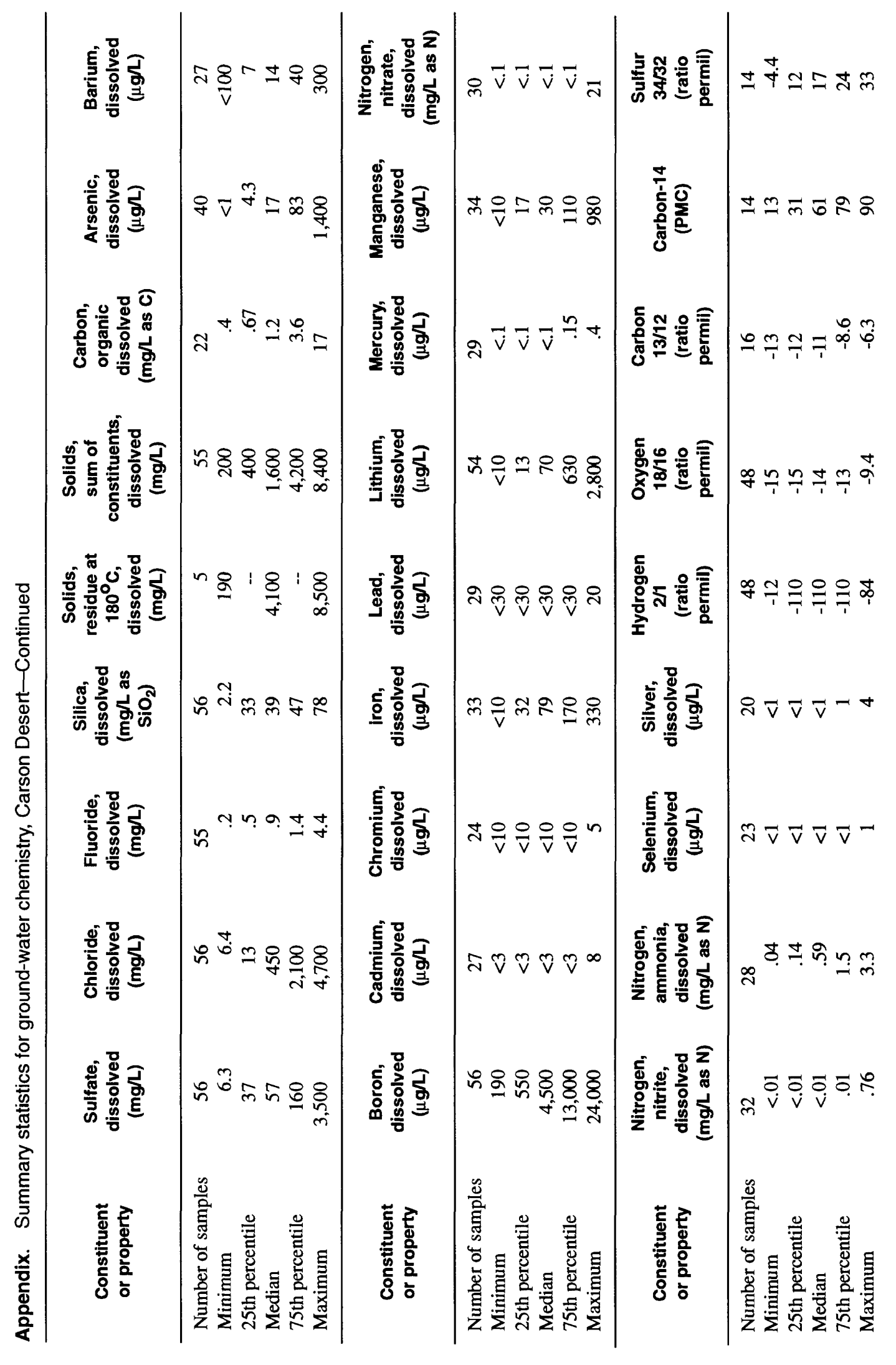




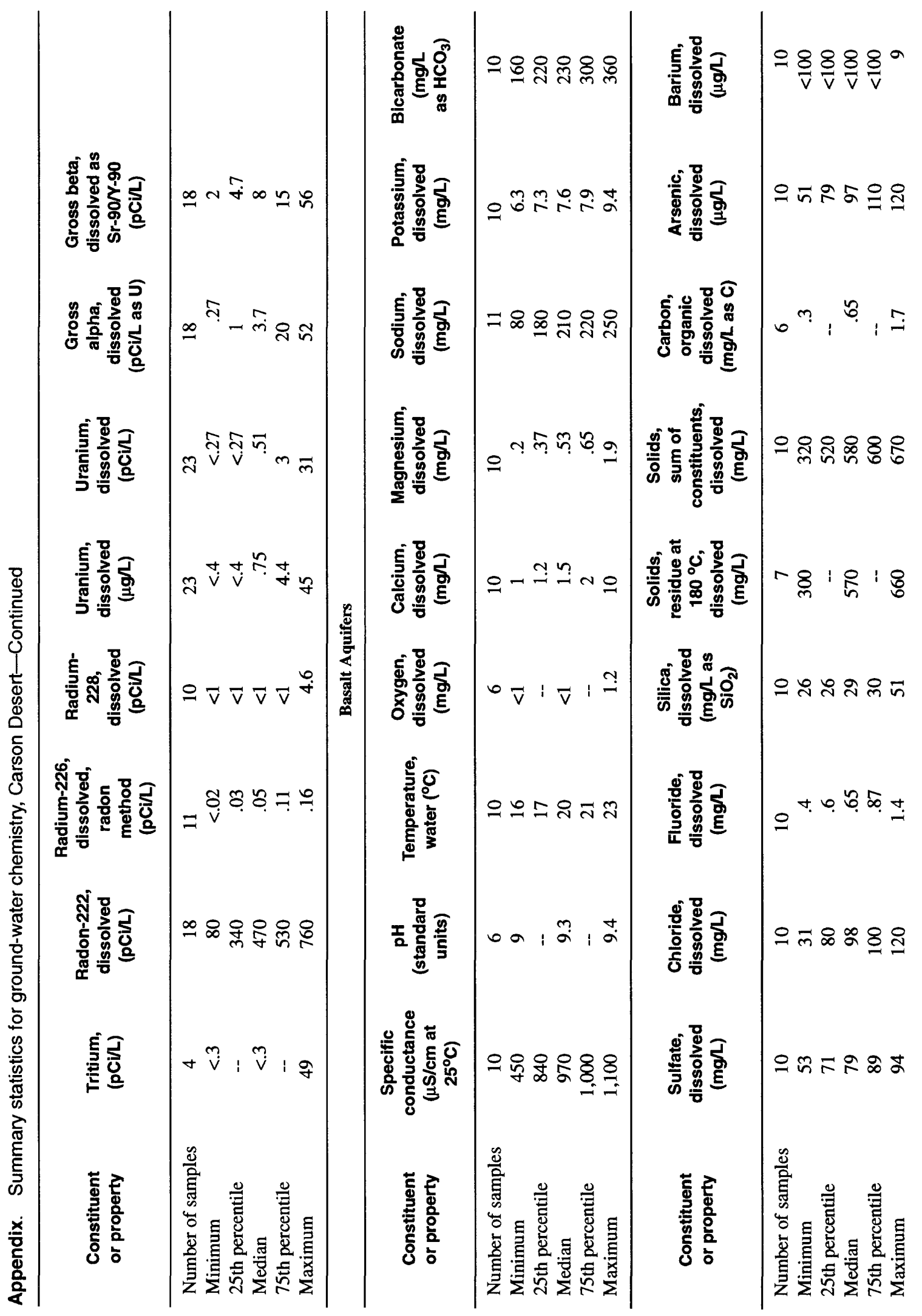




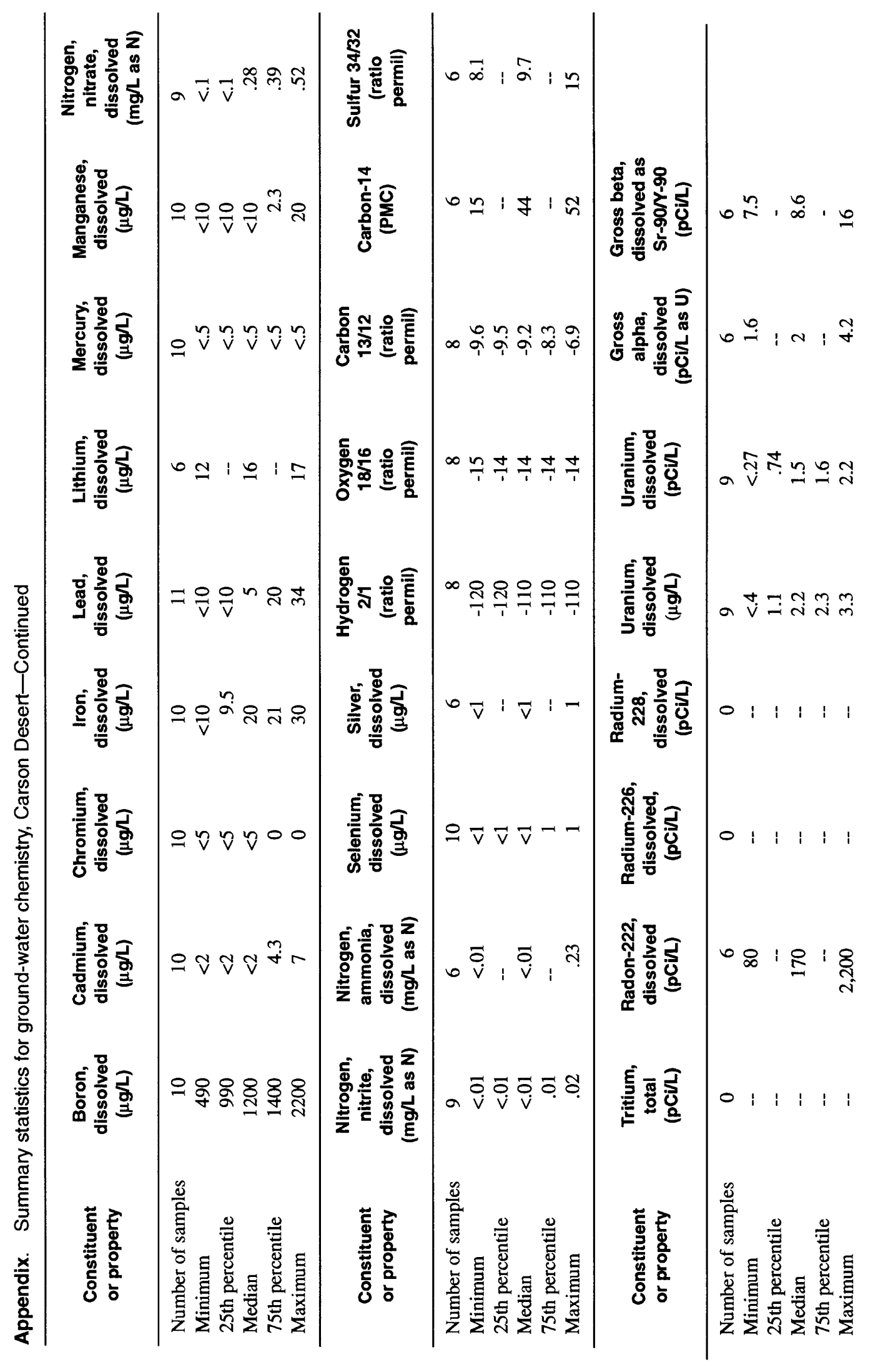




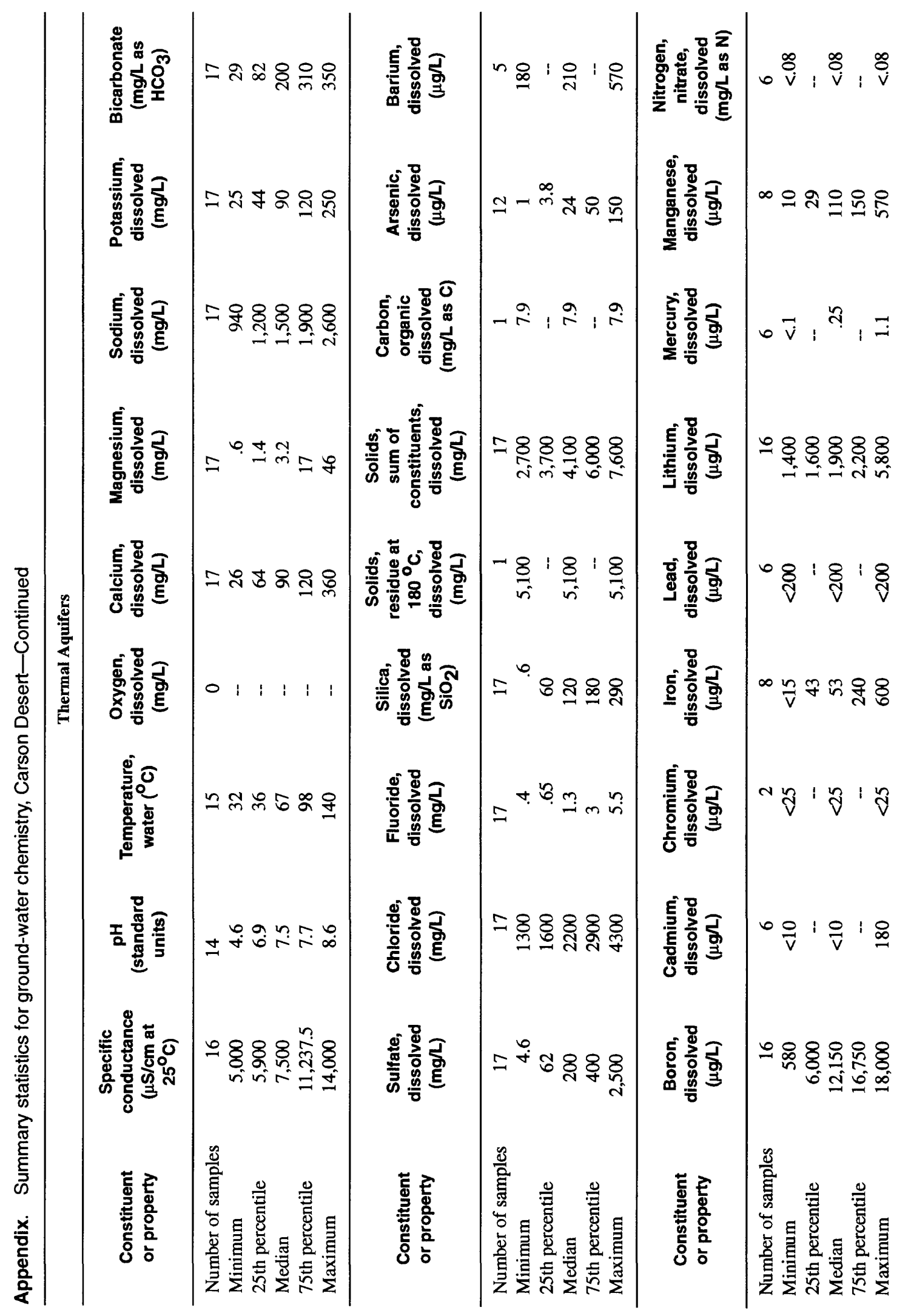




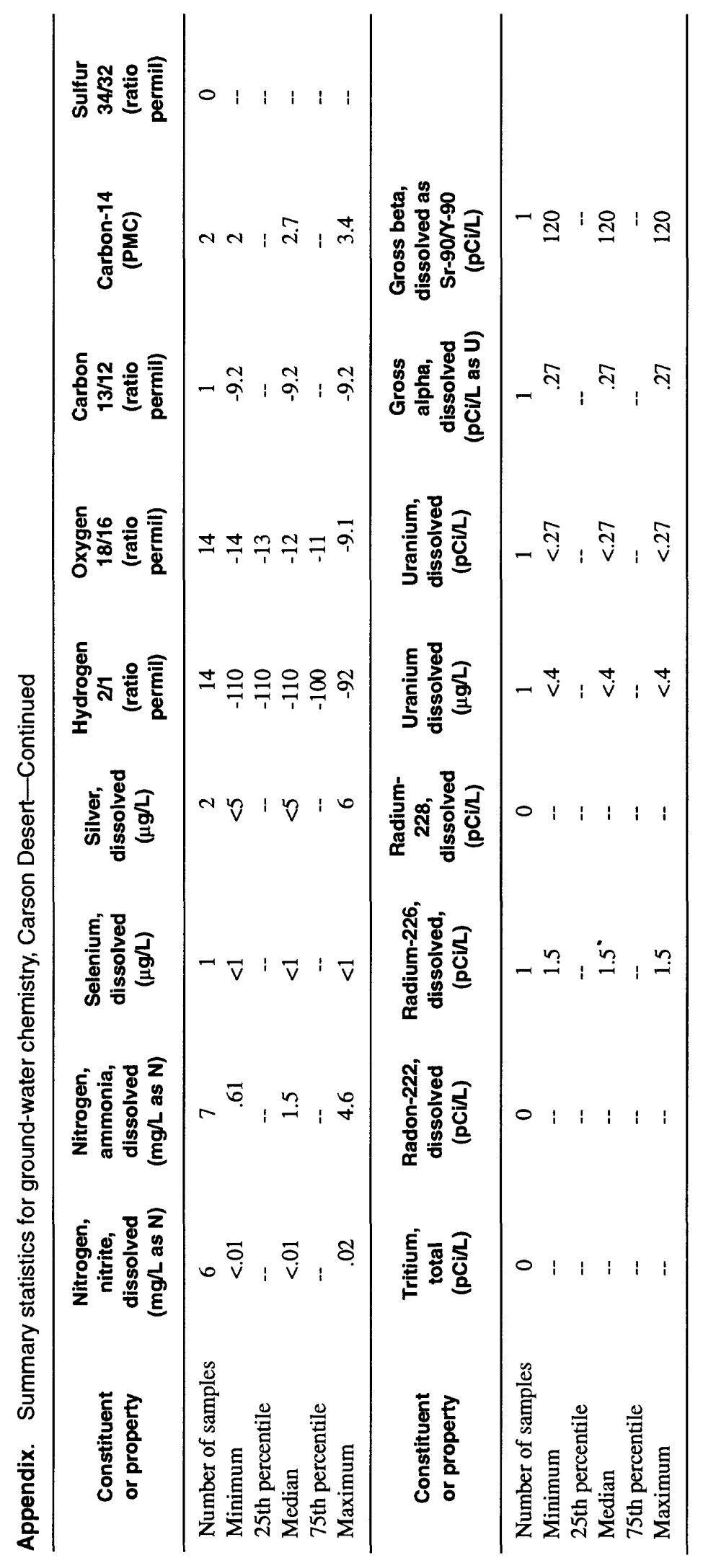

